\title{
MEDIEVÁLNÍ ARCHEOLOGIE V ČESKÉM SLEZSKU
}

\author{
MARKÉTA TYMONOVÁ
}

\begin{abstract}
Abstrakt: Přispěvek mapuje základni etapy archeologického bádáni na územi českého Slezska a přilehlé části severni Moravy od počátku 19. století po současnost. Zminěny jsou osobnosti a instituce, které prispěly $k$ rozvoji archeologie středověku včetně kličových lokalit a výzkumů, jejichž výsledky přinesly poznatky o historii osidlení, opevněných sídlech, urbanizaci, církevni architektuře a hmotné kultuře v obdobi raného a vrcholného středověku.
\end{abstract}

Klíčová slova: medievální archeologie - badatelé - české Slezsko-ranýa vrcholnýstředověk-ranýnovověk.

\section{Medieval archaeology in Czech Silesia}

Abstract: This contribution maps the basic phases of archaeological research in the territory of Czech Silesia and the neighbouring region of northern Moravia, from the early 19th century until the present. The paper gives an account of the people and institutions that have contributed to the development of archaeology of the Middle Ages, including the key sites and excavations the results of which brought information about the history of settlement, hillforts, urbanization, sacral architecture and material culture in the early and high Middle Ages.

Key words: medieval archaeology - researchers - Czech Silesia - early and high Middle Ages - early modern age.

\section{Geograficko-správní vymezení a etapizace bádání}

Sledovaná oblast představuje menší (jižní) část historického Slezska, která zůstala Rakousku po prohraných válkách s Pruskem (1742: Österreichisch Schlesien; 1918: Československé Slezsko; 1993: české Slezsko). Zeměpisně zaujímá oblast horního Poodří, jež v současném správním členění zahrnuje nejsevernější část Olomouckého kraje (okres Jeseník) a kraj Moravskoslezský (okresy Bruntál, Opava, Ostrava-město, Karviná a Frýdek-Místek) s ostravicko-bečevským meziříćím (Místecko, Př́íborsko a Novojicko), které od pravěku tvořilo součást horního Poodří, navzdory tomu, že hranici s Moravou ve středověku fixovala řeka Ostravice (Borák-Gawrecki 1992, 22; Gawrecki a kol. 2003, 162-163; Al Saheb 2004, 79-80). Severní partie Moravy s pásmy Jeseníků a Beskyd představovaly prrirozenou hranici vymezenou tzv. moravsko-slezským pomezním hvozdem, který chránil sídelní komory v předpolí Moravské brány, prostupné několika větvemi zemské stezky. Souvisle byla zalesněna pouze východní strana a nižší polohy byly od neolitu postupně osídlovány (Opravil 1974, 124; Janák-Kouřil 1991a, 194, 197-198; Měchurová 1996, 565; Čapský 2011, 39; Schenk 2004, 10). V západní opavské části regionu se osídlení koncentrovalo na Osoblažsku, Jesenicku, Javornicku a Vidnavsku, dále na Opavsku mezi Hlučínem a Krnovem a Ostravsku; ve východní těšínské části v povodí Olše, odkud se šířilo podél Ostravice směrem k Frýdku (Měř́nský 1989, 23; 1991, 30; 1993, 102; Kouřil 1991a, 98; 1993a, 141).

V historii archeologického bádání lze rozlišit čtyři etapy, z nichž první je vymezena počátkem 19. století, kdy se začaly zachraňovat první archeologické nálezy. Šlo o činnost nahodilou, spojenou se vznikem prvních muzejních kolekcí. Ve druhé etapě po roce 1918 se víceméně pasivní sbírkotvorná činnost postupně měnila v systematické shromažd’ování archeologických nálezů, spojené s prováděním terénních výzkumů, publikováním přehledů osídlení a prezentací nejvýznamnějších památek. Hlavní centrum bádání bylo soustředěno v opavském Uměleckoprůmyslovém muzeu, kde moderní pracoviště vybudovali stavební inženýr Viktor Karger († 1976) a jeho nástupce Gustav Stumpf († 1962), kteří v jazykově a národnostně německé oblasti zahájili profesionalizaci archeologické práce. Druhé centrum se ustavilo v Ostravě a bylo spojeno s činností Karla Jaromíra Bukovanského. Ve třetí etapě po roce 1945, kdy archeologické bádání přešlo 
do českých rukou, se výzkumná činnost zaměřila na slovanské období, středověká opevněná sídla a v rámci poválečné obnovy na výzkumy měst. Garantem byla brněnská pobočka Státního archeologického ústavu, pod níž začala od roku 1955 pracovat opavská expozitura. Zásadní změny ve struktuře archeologických organizací nastaly po roce 1989, kdy v regionu začaly působit nové archeologické instituce, což vedlo k obrovskému nárůstu výzkumné činnosti.

\section{Počátky archeologického bádání (první čtvrtina 19. století - 1918)}

Počátky archeologického bádání jsou v českém Slezsku neodmyslitelně spojeny s činností Gymnazijního muzea, o jehož vznik se v roce 1814 zasloužila řada osobností opavského kulturního a společenského života. Prestižní projekt byl realizován v době, kdy se v habsburské monarchii zakládala první muzea - v roce 1802 v Těšíně a Budapešti a v roce 1811 ve Štýrském Hradci (Šefčík 1984, 2-3). Podle jejich vzoru měl být v Opavě vybudován vědecký ústav, v němž by se skloubila badatelská a tezaurační činnost. Ambiciózní projekt získal podporu intelektuálních kruhů i slezských stavů, ale největší podíl na vzniku muzea měli zakladatelé - profesor dějepisu Faustin Ens († 1852), opavský starosta Jan Josef Schössler († 1834) a amatérský přírodovědec František Mückusch z Buchbergu († 1834), kteří přispěli vlastními kolekcemi, průběžně doplňovanými doklady prŕírodovědné, historické a kulturní hodnoty. Převážná část fondu v počtu okolo šedesáti tisíc předmětů sestávala z př́rodnin a zbylou část tvořily předměty historického a uměleckého charakteru, mezi nimiž nechyběly ani první archeologické nálezy (Tymonová 2005, 79; Kravar 2008, 1).

I když výzkumnou činnost v terénu Gymnazijní muzeum nevyvíjelo, o památky dokumentující nejstarší úsek lidských dějin zájem mělo. Na jejich význam jako jeden z prvních poukázal Josef Dobrovský († 1829), jehož polemické spisy přispěly k uznání „starožitností“ za autentické historické prameny (Sklenáŕ 1970, 280). Podobně na hmotné památky pohlížel Pavel Josef Šafařík († 1861), jehož Slovanské starožitnosti (1836 a 1837) položily základ tzv. slovanské archeologie (Měřínský 2014, 18), a první profesor archeologie na Karlově univerzitě Jan Erazim Vocel († 1871) pro dobu křestanského věku, jehož kontakty s Františkem Palackým († 1876) obohatily prehistorické bádání o pozitivistický prŕístup k materii (Wocel 1850, 542; Sklenáŕ 1970, 280; 1971; 1981; 2005, 625-626).

Snahy o záchranu a uchovávání předmětů archeologické povahy našly zázemí v institucích vzdělávacího a později muzejního charakteru. Až do roku 1882, kdy v Opavě vzniklo Uměleckoprůmyslové muzeum (Kaiser Franz Josef-Museum für Kunst und Gewerbe in Troppau), sbírkotvornou aktivitu vyvíjel pouze gymnazijní ústav, v němž se akvizice ukládaly do mechanicko-fyzikálního kabinetu. O jeho obsahu informují inventáře z let 1835-1878 a fyzicky dochované nálezy ve Slezském zemském muzeu, kam se gymnazijní sbírka postupně předávala v letech 1905-1945. Převážně šlo o pravěký materiál, až na nálezy z hradu Cvilína (kachel a dvě šipky), Ostrožné ulice v Opavě (džbánek z 15. století) a velkostatku v Holasovicích (mozaikové dlaždice vykopané v roce 1846), o nichž v roce 1870 informoval Anton Peter († 1898), působící jako konzervátor Gymnazijního muzea (Peter 1870, 80-81).

První známé nálezy z holasovického dvora - nejstarší archeologické lokality v českém Slezsku - pocházely z roku 1812, kdy byly při stavbě stájí objeveny základy kostela, který vídeňský publicista Franz Sartori († 1832) považoval za templářský. Stejného mínění byl Faustin Ens († 1858), vzdělaný iluminát a první správce muzejních sbírek (Sartori 1818, 181; Ens 1837, 66-67; Peter 1870, 80-81; Jisl 1965, 7; Zezula 2019, 10). Ve své čtyřrílné topografii Opavska (Oppaland), vydané v letech 1835-1837, popsal počátky muzea, přírodovědné sbírky a ve třetím díle slezské starožitnosti. Kromě kuriozit přivezených ze zahraničí se většinou jednalo o náhodně zachráněné předměty z pravěkého a středověkého období (Kravar 2014, 32).

Ve druhé polovině 19. století se v Těšínském Slezsku začalo profilovat ještě druhé muzejní centrum, reprezentované ždánickým rodákem Karlem Jaromírem Bukovanským († 1932), jenž od roku 1870 učil v Polské (dnešní Slezské) Ostravě, kde o dvě léta později založil muzeum. Základ 
fondu tvořila sbírka, kterou shromažd’oval již od působení na jižní Moravě, v níž vedle předmětů etnografického a historického charakteru nechyběly archeologické nálezy, postupně doplňované o sběry ze Zárubku, Salmovce, Mundlochu, Slezskoostravského hradu a Moravské Ostravy (Pokludová 2005, 26-29, 34-35; Moravec 2011, 109; 2019, 11-12; 2014, 78). Nedostatek prostor a vzrůstající obavy o další osud kolekce prriměly Bukovanského, aby sbírku v roce 1903 prodal městu, které rok nato pro ni zř́idilo obecní muzeum v budově bývalé tiskárny Union. Po odchodu Bukovanského na odpočinek (1907) a ukončení nájemní smlouvy (1911) bylo muzeum zrušeno a sbírky byly provizorně deponovány v různých místech (Měchurová 2014a, 81; Palowská 2015, 103). Spolu se slezskoostravským muzeem vznikla v témže roce ještě dvě další muzea v Moravské Ostravě (české Průmyslové a živnostenské museum a německé Industrie- und Gewerbemuseum für das Ostrau-Karwiner Rewier), která se po první světové válce sloučila v Umělecko-průmyslové museum Ostravsko-karvinského revíru. Žádné se však v záchraně archeologických památek výrazněji neangažovalo (Měchurová 1996, 566).

S obtížemi se od poloviny 19. století potýkalo také opavské Gymnazijní muzeum, které kvůli nedostatku financí přestalo vyvíjet veřejnou činnost, jelikož bylo institucí říšskou, nikoli zemskou (Kravar 2008, 3). Naopak nově vzniklé Uměleckoprůmyslové muzeum podporu zemských kruhů mělo, avšak za vedení Edmunda Wilhelma Brauna († 1957) zájem o prehistorii nikterak neprojevovalo. Aby si obě muzejní instituce navzájem nekonkurovaly, rozdělily si sféry působení tak, že se školní ústav zaměřil na bádání přírodovědné a zemský na historické a uměnovědné. Podceňování významu archeologického materiálu se uměleckoprůmyslovému muzeu stalo osudným při pořádání putovního sjezdu Vídeňské antropologické společnosti v roce 1903, kdy si předměty pro plánovanou výstavku muselo vypůjčit z Muzea Matice opavské, vzniklé v roce 1884 zásluhou Vincence Praska († 1912) a Josefa Zukala († 1929), s jejichž pomocí v roce 1901 otevřelo expozici v Matičním domě na Rybím trhu (Kulka 1903, 89-99; 1922a, 7-8; Černohorský 1927, 10; Jis1 1964, 126; Tymonová 2005, 81; Kravar 2008, 3; Skalická 2014a, 119; 2014e, 117).

V pořadí třetí opavské muzeum se zaměřilo na osvětovou činnost a publikování krátkých zpráv ve Věstníku Matice opavské a Opavském Týdeníku, které v roce 1899 využil profesor gymnázia a jednatel Matice Opavské Josef Pospíšil († 1936) při sepisování Krátkého prehledu predhistorických památek slezských. Rozsáhlejší historicko-topografická kompendia zpracoval jazykovědec a historik Vincenc Prasek (Historická topografie země Opavské, Dějiny kraje Holasovského čili Opavského a Dějiny knižectví Těšinského), který se stal v roce 1883 ředitelem prvního českého gymnázia v Opavě (Prasek 1889; 1891; 1894; Š́l 2010, 59). V informativních článcích psal o hradě Cvilíně (Šelenburg), mohylníku ve Stěbořicích, hradisku v Chotěbuzi, hradu Vikštejnu nebo o opevnění v Kylešovicích (Prasek 1875; 1875a, 334; 1885; 1886; 1886a). Osvětlování významu lokalit mělo poučit veřejnost o důležitosti záchrany prehistorických památek a zvýšit všeobecné historické povědomí.

Absence archeologických nálezů v Uměleckoprůmyslovém muzeu dala impulz k okamžité nápravě, a proto výtěžky odkryvů, které účastníci sjezdu provedli v Holasovicích a Úvalně, předali pořadatelům jako základ nového fondu a ke koupi doporučili kolekci holasovického kováře Frömmela (Jisl 1964, 125). Muzeum ji získalo v roce 1908, avšak až na několik pozdně hradištních střepů obsahovala převážně pravěký materiál. Daleko cennější akvizici představoval stř́ibrný prsten s broušeným křištálem z konce 12. a počátku 13. století (obr. 1), který se našel v roce 1905 na pozemku rolníka Roberta Schreiera, situovaném v centru obce (Šikulová 1993, 83-84; Skalická 2014b, 120; Zezula 2019, 11).

Protože nálezy v muzeu přibývaly a neměl je kdo zpracovat, byl v roce 1913 ředitelem Braunem smluvně zaměstnán stavební inženýr Viktor Karger († 1976), jehož pracovní angažmá zahájilo profesionalizaci slezské archeologie (obr. 2), která až do konce druhé světové války zůstala výhradně v německých rukou. Čerstvý absolvent Technické univerzity ve Vídni se náročného úkolu zhostil s nebývalou erudicí, i když odborné vzdělání ve skutečnosti neměl a archeologické vědomosti nabyl z přednášek univerzitních profesorů Moritze Hoernese a Oswalda Menghina. Za pomoci př́tele ze studií, a od roku 1922 i svého nástupce, Gustava Stumpfa († 1962) nezpracované 
nálezy roztř́́dil a od roku 1913 je začal evidovat $\mathrm{v}$ inventáři, do něhož postupně zapisoval převody z Gymnazijního muzea (1905) a další akvizice včetně vlastních nálezů (Bakala 1970, 2; Jisl 1964, 126; Poloczkowa 1977, 184; Šefčík 1987, 28; 1998, 459; 2001, 773; Sklenář 2005, 27; Tymonová 2010, 64-65; Kostrhun 2014, 99; Bříza-Janáková 2016, 50). Řadu přírůstků získal během úředních výzkumů, které v roce 1916 provedl na hradě Přerovci (Karger 1917, 140), následujícího roku na hradisku v Chotěbuzi-Podoboře a $v$ roce 1922 v Holasovicích, kde $\mathrm{v}$ místě hospodářského dvora odkryl sedm mladohradištních hrobů (Karger 1917; 1922, Bericht, 146; 1922, 31-32; Jisl 1952, 44; Zezula 2019, 11).

\section{Archeologické bádání mezi světovými válkami (1918-1945)}

Výsledky Kargerovy systematické práce se zúročily po první světové válce, kdy muzeum uspořádalo stálou výstavu nálezů (1921) a vydalo první syntézu pravěku (1922) v dvoujazyčné verzi (Stumpf 1921, 57; Karger 1922; 1922a; Janák 1997a; Skalická 2014c). V českém Slezsku se tak ustavilo první archeologické pracoviště, které bylo schopno krátce po vyhlášení republiky vyvíjet terénní, sbírkotvornou, prezentační a publikační činnost (Jisl 1964, 126). Karger se však i přes zjevné zásluhy ocenění nedočkal, protože společenské poměry po roce 1918 nebyly říšskému Němci bez znalosti češtiny prŕlišs nakloněny. Po převedení muzea do zemské správy (Slezské zemské museum - Schlesisches Landesmuseum) byl v roce 1921 kvůli nabytému polskému občanství ze služeb propuštěn, což jej přimělo k odchodu do rodného Těšína (polského Cieszyna), kde od roku 1925 začal pracovat v místním muzeu jako respektovaný numismatik a kunsthistorik a do roku 1938 jako ředitel. Po okupaci byl sice znovu povolán do služby, ale setrval v ní pouze do konce války (Šefčík 1987, 29; Golec-Bojda 1995, 86-87; Bartholomäus 2011, 225-230).

Zásluhou archiváře a středoškolského profesora Aloise Adamuse († 1964) vzniklo roce 1924 v Moravské Ostravě městské muzeum, do něhož byly prrevedeny sbírky ostatních muzeí včetně Bukovanského kolekce. Až do

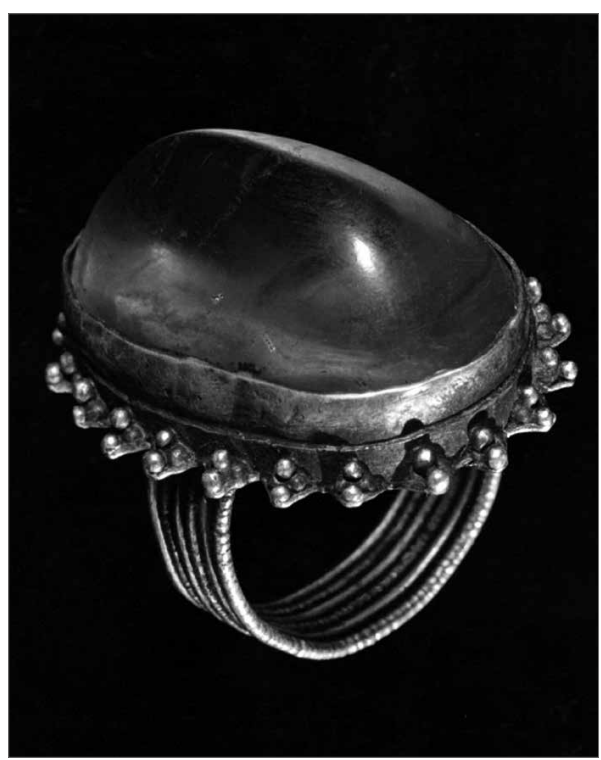

Obr. 1. Holasovice - Dvůr. Stř́ibrný prsten s křišt’álem. Zdroj Fotoarchiv Slezského zemského muzea.

Abb. 1. Holasovice - Dvůr. Silberring mit Kristall. Quelle Fotoarchiv des Schlesischen Landesmuseums.

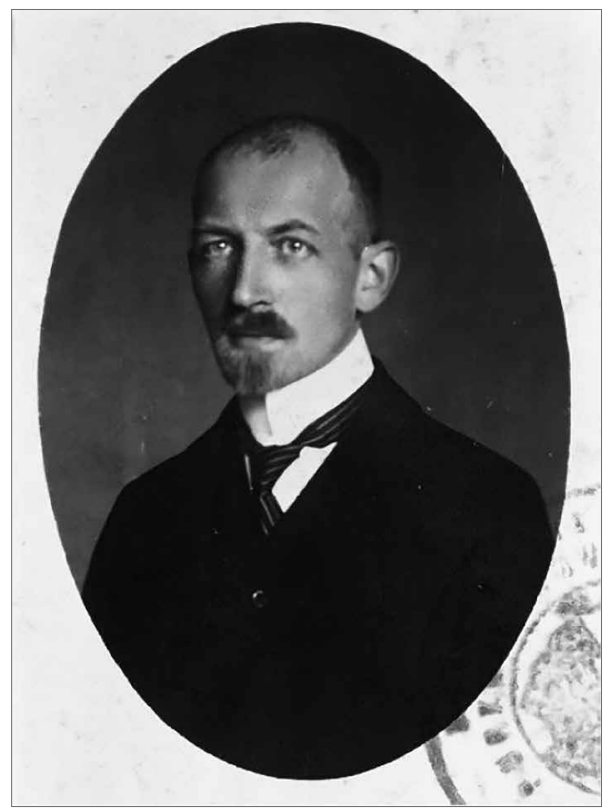

Obr. 2. Viktor Karger. Zdroj Fotoarchiv Slezského zemského muzea.

Abb. 2. Viktor Karger. Quelle Fotoarchiv des Schlesischen Landesmuseums. 


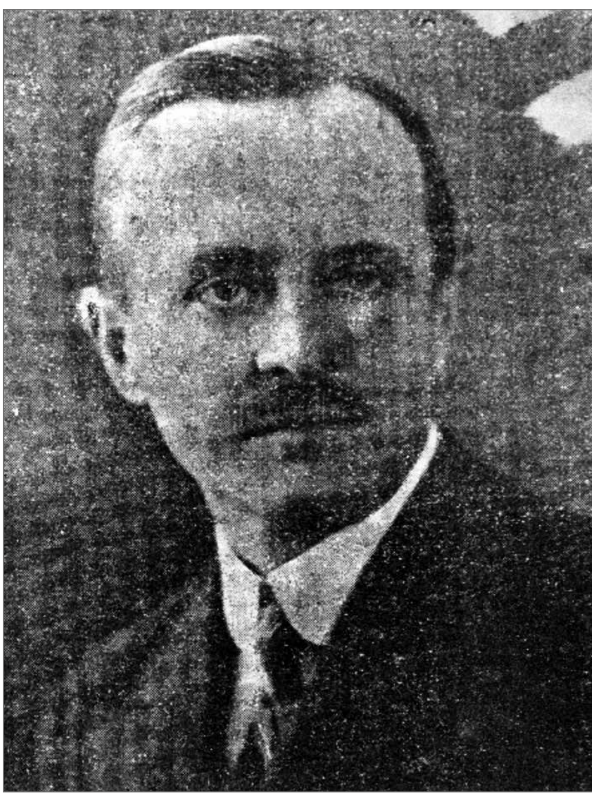

Obr. 3. Gustav Stumpf. Zdroj Fotoarchiv Slezského zemského muzea.

Abb. 3. Gustav Stumpf. Quelle Fotoarchiv des Schlesischen Landesmuseums. roku 1931 sídlilo v Mariánských Horách, ale po vybudování Nové radnice, získalo objekt Staré radnice na Masarykově náměstí, kde sídlí dodnes (Janeček 2017, 118-123). Ředitel Adamus se během dvanáctiletého pobytu v Ostravě zabýval nejen regionální historií, ale i archeologií. V roce 1924 provedl amatérský výkop na vrchu Landek, v němž pak do roku 1937 s přestávkami pokračoval důlní inženýr Jan Folprecht, který zjistil, že středověkému hradu předcházelo starší osídlení (Folprecht 1996, 23; Měchurová 1996, 567; Kostrhun 2013, 123).

Personální změny nastaly po Kargerově odchodu ve Slezském zemském muzeu, kde uvolněné místo obsadil nejprve Václav Vendl († 1957), původem z Mladé Boleslavi, který tíhnul spíše $\mathrm{k}$ dějinám výtvarného umění než k archeologii (Šefč́́k 1981, 184-192; Šopák 2001, 184-192; Skalická 2014, 217). Po více než roce jej vystřídal Gustav Stumpf (obr. 3), jenž práci vykonával převážně ve volném čase a bez nároků na odměnu. Jeho činnost se soustředila na rozšiřování sbírky, do níž zapisoval nálezy získané z Městského muzea (1923), jež vzniklo v roce $1896 \mathrm{z}$ iniciativy Ing. Moritze Hartla († 1905) v budově radnice na Horním náměstí (Černohorský 1927, 5;

Šefčík 1982, 59-61; Písková 1997, 154-155; Sklenář 2005, 546; Dvořáková-Polách-Zezulčík 2016, 159). Zároveň evidoval vlastní sběry a materiál získaný formou darů či koupí z Opavska (Kostelní kopec v Jaktaři, hradisko v Kylešovicích; Stumpf 1928), Krnovska (hrady Cvilín a Vartnov), Javornicka (hrady Rychleby a Kaltenštejn; Stumpf 1912; 1915) a Novojicka (Kotouč u Štramberka; Stumpf 1926, 132-134; Knápek 2010, 28; Velké Albrechtice u Bílovce). S Kargerovou pomocí sestavil v roce 1927 mapu a soupis archeologických lokalit českého Slezska, rozlišených podle období a druhu naleziště (Janák 2001, 773; Tymonová 2005, 81-82; Kostrhun 2016, 112-113; Skalická 2014d, 214-215; Bříza-Janáková 2016, 58). Po reorganizaci státní správy a vzniku Země moravskoslezské byl v roce 1929 přeložen na okresní úřad do Nového Jičína a krátce nato na zemský úřad v Brně, kde pracoval jako technický rada zemského stavebního úřadu. S odchodem se vyrovnával velmi těžce, protože ztratil kontakt se Slezskem, jehož výzkum pojímal jako svůj životní úkol. Po svém penzionování v roce 1935 se vrátil do Nového Jičína, kde žil až do osvobození, a pak přesídlil do německé Fuldy (Šefč́í 1978, 50-51; 1982, 59; 1984, 31-2; 1987a, 51-52; Swiač 2012, 100).

V předválečných letech 1929-1935 spravoval archeologickou sbírku v Opavě Rudolf Přihoda († 1956), penzionovaný dělostřelecký důstojník s interesem o středověkou archeologii (Jisl 1957, 3; 1964, 127; Sklenáŕ 2005, 468; Tymonová 2005, 82). Na Opavsku a Jesenicku provedl několik menších sběrů, které zapsal do sbírek. V roce 1930 zaevidoval materiál z hradu Rychleb a později nálezy z hradu Cvilína, kde od roku 1933 kopal krnovský stavitel Gustav Adolf Horny v rámci památkové obnovy objektu (obr. 4). Dohled nad vykopávkami vykonával z titulu zemského konzervátora pro německé části Slezska ředitel Braun, který měl s vlastníkem pozemku dohodu o předávání nálezů (Šopák 2008, 48, 90-91). Protože byl v roce 1935 penzionován a toho roku muzeum opustil také Rudolf Přihoda, nálezový materiál se přestal předávat a zůstával v Hornyho domě v Krnově. Část ještě stačil převzít Přihoda za krátkého pobytu v Opavě v roce 1942, ale 


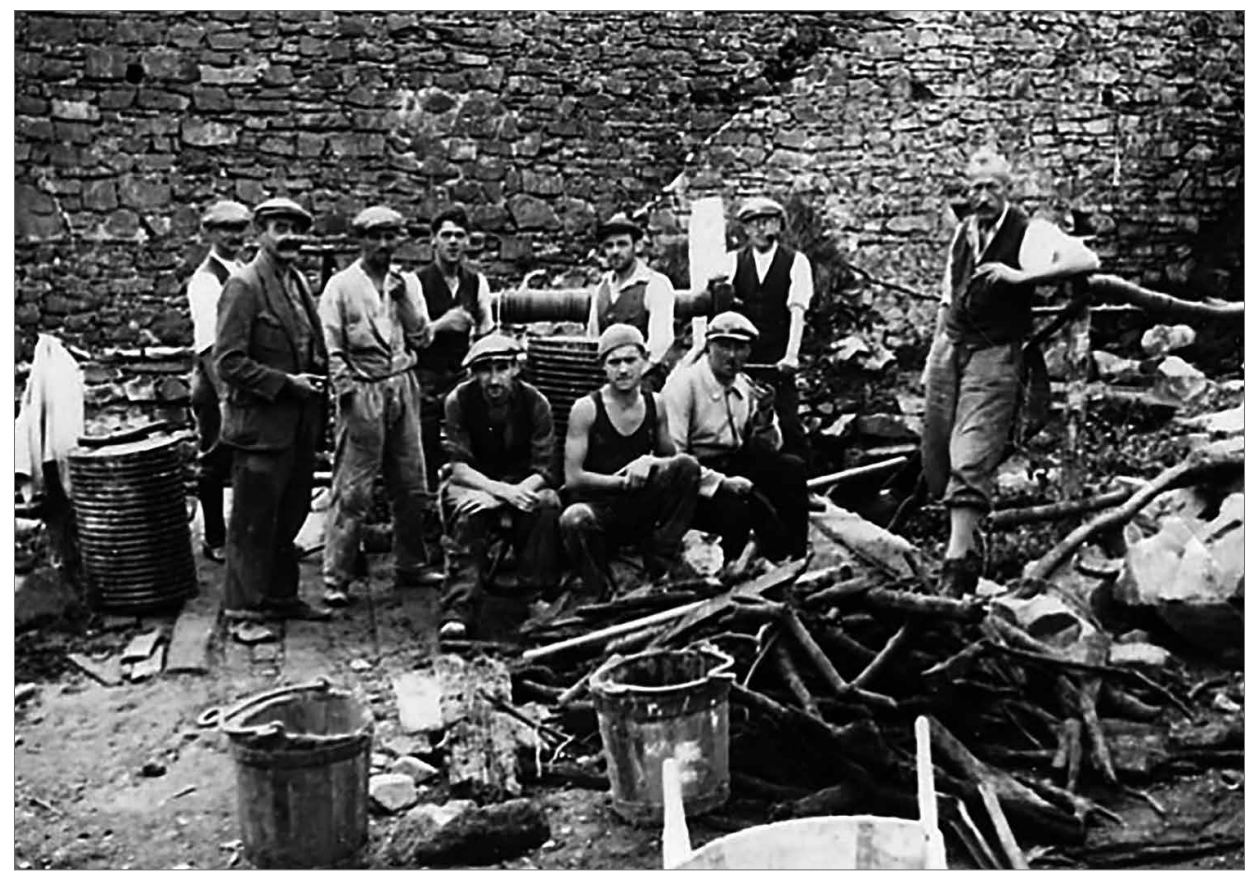

Obr. 4. Cvilín. Gustav Adolf Horny (vpravo) s pracovníky při odkryvu hradu Cvilína (Schellenburgu) v roce 1934. Zdroj Archiv Městského muzea v Krnově.

Abb. 4. Cvilín. Gustav Adolf Horny (rechts) mit Arbeitern bei der Freilegung von Burg Cvilín (Schellenburg) im Jahr 1934. Quelle Archiv des Stadtmuseums Krnov.

zbytek byl do Opavy převezen až v roce 1950 (Šikulová 1993, 14; Tymonová 2010, 64; Bříza-Janáková 2016, 23, 55-56).

Po Braunově odchodu řídil muzeum Karel Černohorský († 1982), původně zaměstnanec Obilního úřadu v Opavě a od roku 1921 muzejní asistent. Dějiny umění studoval při zaměstnání a odborně se zabýval středověkou keramikou se zaměřením na fajánsovou produkci (Braun-Černohorský 1925; Černohorský 1928; 1941; 1964; Kouřil-Wihoda 2003, 95-96). O archeologické výzkumy se živě zajímal a sám se jich aktivně účastnil, což potvrzuje zápis v inventární knize, podle něhož ještě v dubnu 1938 prováděl s Wernerem Kudlichem výzkum na statku v Holasovicích. Na podzim téhož roku byl v důsledku záboru pohraničí propuštěn a pracovní ,azyl“ nalezl v zemském muzeu v Brně, kde spravoval fond numismatiky až do svého předčasného penzionování v roce 1942. V Opavě byl mezitím na místo ředitele znovu povolán sedmdesátiletý Braun, jenž ve funkci setrval do konce války, kdy se ještě snažil organizovat svozy sbírek ukrytých na okolních zámcích. Od roku 1946 začal pracovat jako poradce v Germánském národním muzeu, z něhož původně do Opavy přišel (Bakala 1964a, 55; Nekuda 1969, 40-42; Šefčík 1984, 18-20; Šopák 2006, 155; 2008, 91, 103; Novotný 2009, 14-16).

Centralizační opatření zavedená protektorátní německou správou postihla všechna opavská muzea, která byla, až na městské, sloučena v jedno Říšské župní muzeum (Reichsgaumuseum), v jehož čele stanul Werner Kudlich († 1945), pověřený dohledem nad muzei ve východní části Říšské župy Sudety. Koncem roku 1939 narukoval na východní frontu, ale ještě v roce 1942 se nakrátko vrátil, anžto byl jmenován komisařem pro památkovou péči v sudetské župě okresu Opava. Následujícího roku byl opět na frontě, kde se s Rudolfem Přihodou účastnil rabování uměleckých památek (Šefč́́k 1989, 175-180; Janák 2001, 777). 
S ředitelem Kudlichem byl od roku 1938 v písemném styku Herbert Alois Weinelt († 1943) ohledně časopisu Deutsche Volksforschung in Böhmen und Mähren, který mělo vydávat muzeum, avšak z projektu nakonec sešlo. Jesenický rodák a absolvent lingvistiky na Německé univerzitě v Praze proslul jako znalec hradní architektury, ovlivněný teoriemi Carla Schuchhardta (Schuchhardt 1931), jehož typologii postavenou na etnickém principu převzal a aplikoval ve své koncepci opevněných sídel, které dělil na typ sasko-germánský a fransko-normanský (Unger 1971, 230; Úlovec 1996, 13). V roce 1934 publikoval první články o Cvilíně (Schellenburg) a opevněných sídlech v okolí Vrbna; po dalších dvou letech psal o fortifikacích v Jeseníku, Javorníku, Skorošicích a Adolfovicích, které přiřadil k fransko-normanskému typu. Za jeho stavebníky ve 13. století považoval Němce a teprve o století později jej měli přejímat Slované. Datování opíral o nestratifikované nálezy a složitost stavební dispozice bez opory v písemných pramenech, na což poukázal Zdeněk Gardavský a později Pavel Kouřil s Miroslavem Plačkem (Weinelt 1934; 1934a; 1936; Kouřil-Plaček 1986, 221; Minařík 2019, 18-19). Po studiích pracoval na německé Karlově univerzitě jako asistent a v roce 1940 byl jmenován docentem německé národní vědy a výzkumu na univerzitě v pruském Königsbergu (dnes ruský Kaliningrad). Nastoupit tam nestačil, jelikož byl odvelen na západní frontu do Bretagne, kde se věnoval průzkumu místních hradů. Když byl o dvě léta později převelen na východní bojiště, vyřídil si místo v pražském archeologickém ústavu v oddělení středověké archeologie, ale opět nestihl nastoupit, protože roku 1943 padl u Hadače v charkovské oblasti na Ukrajině (Blažek 2003, 588; Minařík 2019, 32-37).

Za Kudlichovy nepř́tomnosti (1939-1940) spravoval archeologickou sbírku absolvent brněnské techniky Hans Freising († 1977), který pod patronací Úřadu pro pravěk (Amt für Vorgeschichte) prováděl výzkumy u Moravské Třebové a Jevíčka v souvislosti s výstavbou tzv. Moravské dálnice mezi Vídní a Vratislaví (Jisl 1964, 128; Čižmář 2005, 479-481; Sklenář 2005, 174-175; Tymonová 2005, 82; Kirsch 2008, 209; Sklenář-Vlašímský 2015, 372-373; Hlava 2019, 162). Práci za nepř́tomného Freisinga suploval od roku 1939 v Opavě Wilfried Titze († 1993), zaměřený na průzkumy a dokumentaci opevnění na Opavsku, Jesenicku a Novojicku. Z raně středověkých hradisek zkoumal objekty ve Víně u Slezských Rudoltic a v Opavě-Kylešovicích (obr. 5); ze středověkých hrady Cvilín, Fulštejn, Koberštejn, Leuchtenštejn, Luginsland, Vartnov a tvrze v Albrechticích nebo Heřmanovicích (Titze 1941; Kouřil-Prix-Wihoda 2000, 23; BřízaJanáková 2016, 29). O rok později získal místo muzejního laboranta javornický rodák Bruno König († 1945), který působil jako úředník komorního ředitelství vratislavského biskupství a zasloužil se o vznik javornického muzea, založeného v roce 1902 (Pachl 1983, 236; Brachtl 1994, 40; Macháček 2011, 6). Mezi lety 1903-1904 a 1909-1910 prováděl za dohledu Gustava Stumpfa výzkum hradu Rychleby, finančně podporovaný vratislavským biskupem Georgem Koppem a javornickou sekcí Moravskoslezského sudetského horského spolku (König 1910; Kouřil-Prix-Wihoda 2000, 313; Rychlý 2018, 20). S jeho jménem byl spojen také výzkum hradu Karpenštejn, který leží na polské straně (König 1904-1905).

Odborný dohled nad archeologickými výzkumy prováděl za památkovou péči Georg Raschke († 1973), ředitel Zemského úradu pro pravěk Horního Slezska (Landesamt für Vorgeschichte Oberschlesiens) se sídlem v Ratiboři, pod nějž spadala polská území připojená k řŕši s městy Opolí a Katovicemi. Jeho snahy o rozšíření vlivu a podřízení opavských laborantů díky zásahu ředitele Brauna neuspěly, a proto se zaměřil na Zámeckou horu v polském Těšíně, kde v letech 1941-1942 odkryl základy románské rotundy a hřbitov s pětatřiceti kostrovými hroby (Jež-Pindur 2010, 186; Raschke 1941, 157). Ve stejné době se zajímal o hradisko v Kylešovicích, což dokládají hlášení zaslaná Úřadu pro pravěk v Teplicích-Šanově a Říšskému muzeu v Opavě, jejichž opisy se po válce dostaly do rukou ředitele Státního archeologického ústavu v Praze Jaroslava Böhma († 1962), který na jejich základě inicioval poválečný zjištovací výzkum Josefa Poulíka (Michnová-Polanský-Tymonová-Tomková 2010, 100; Kouřil 1994, 33). Když v roce 1942 Raschke nastoupil vojenskou službu, služební agendu za něj vyřizovala jeho žena Gertruda (Měchurová 1996, 569; Hlava 2019, 12, 77-78, 173, 177). 


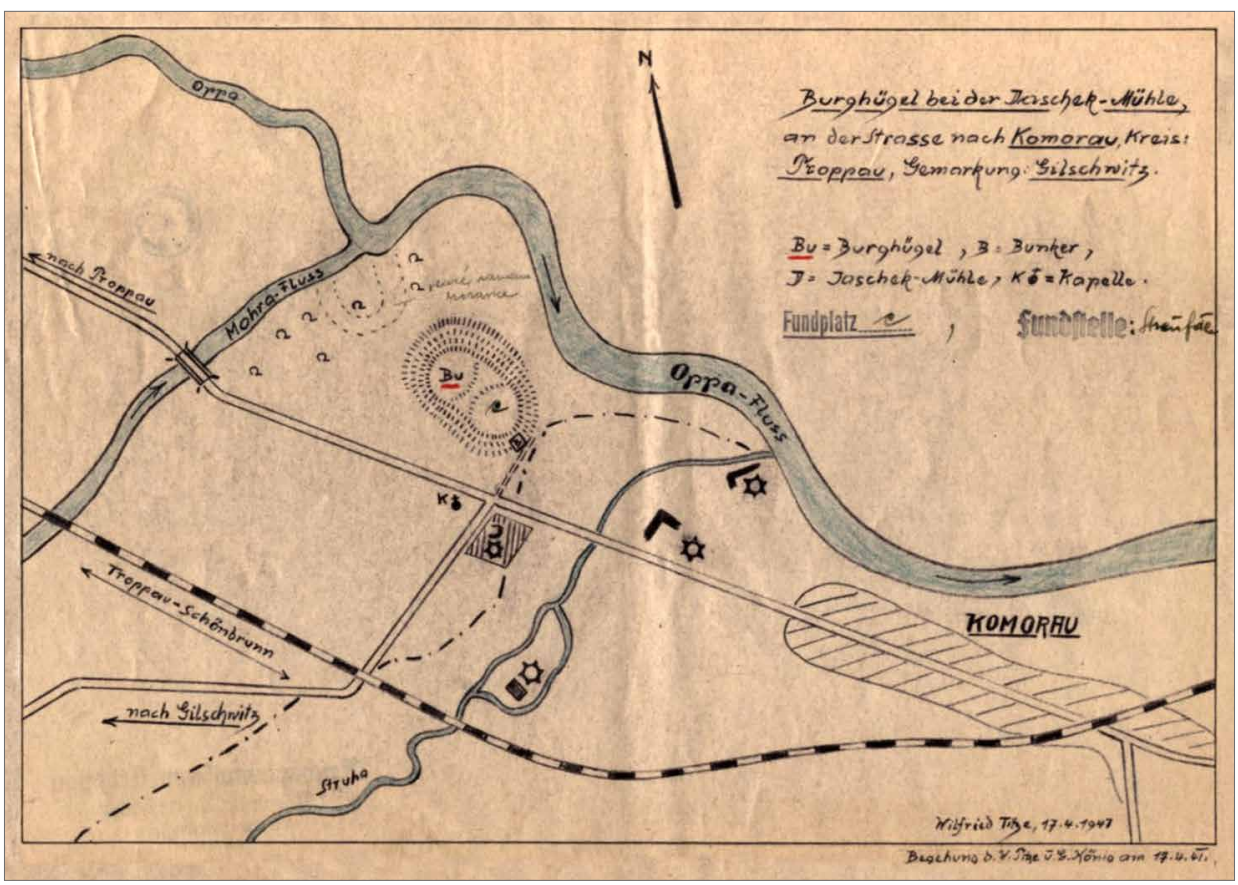

Obr. 5. Opava-Kylešovice. Plánek hradiska pořízený Wilfriedem Tietzem v roce 1941 s pozdějším čerchovaným zakreslením původního toku Moravice. Zdroj Archiv Slezského zemského muzea v Opavě.

Abb. 5. Opava-Kylešovice. Von Wilfried Tietze im Jahr 1941 angefertigte Planskizze der Burgstätte mit späterer strichpunktierter Einzeichnung des ursprünglichen Flusslaufs Mohra. Quelle Archiv des Schlesischen Landesmuseums in Opava.

Těsně před okupací v roce 1939 byl pověřen správou pražského ústavu Jaroslav Böhm, který situaci ve Slezsku znal díky studii Slezsko v době prehistorické, kterou zveřejnil v roce 1926 ve Vlastivědném sborníku slezském. Při jejím zpracování vycházel z Kargera, nebot' až na Hradec u Opavy v ní uváděl stejné lokality, jež neměly být podle něj starší než z 11 . století. (Jisl 1952a, 33; Janák 2001, 775-776; Rataj-Šole-Vencl 2003, 156; Smetánka 2008, 740; Kostrhun 2013, 122; Hlava 2017, 18). V samém závěru shrnul stav poznání slovanského období a vytyčil hlavní úkol dalšího bádání: „Zi̊stává tedy di̊ležitá a dlouhá doba prvního tisíciletí po Kr. téměr úplně neznáma. Počátky slovanské kolonizace, nejvýznamnější kapitola domácích dějin, jest nejvice zanedbána. Rozluštěni této otázky neni v historických pramenech. Ty jsou již vyčerpány a ani nejpilnějši studium nepřinese světlo. Co historie mohla o počátcích našich dějin řici, to již všechno pověděla. Zbývá jediný pramen, nezávislý na citech a vůli člověkastarožitnosti“" (Böhm 1926, 30).

Až do konce války se tento dluh nepodařilo vyrovnat, protože scházely prostředky, profesně vzdělaní odborníci a především ideologicky nezatížený výzkum, jehož podpora se ze strany německých úřadů nedala očekávat (Kouřil-Gryc 2019,93). O to větší váhu měl program poválečného výzkumu, který vznikl Böhmovou zásluhou. Konkrétní obsah nabyl za protektorátu v roce 1940, kdy vznikla Koncepce rozvoje Státního archeologického ústavu v Praze, v níž bylo uvedeno: „Obdobi slovanské je bohužel posud nejvice zanedbané a jemu bude věnována největši péče. A to všem třem skupinám nálezovým, pohřebištím, sídlištím i hradištím. “ (Hlava 2017, 32-36) Zvláště to platilo pro české Slezsko, kde byly slovanské nálezy velice chudé, jak konstatoval Josef Skutil († 1965) v referátu $Z$ nejdávněǰ̌i minulosti Slezska, př̀edneseném v roce 1946 na půdě Masarykovy univerzity v cyklu Slezsko, český stát a česká kultura, k jehož knižnímu vydání došlo ještě 
téhož roku. Preferování slovanského výzkumu nebylo v tomto regionu motivováno ideologickými pohnutkami, nýbrž prozaickým faktem, že se o raně středověkém osídlení téměř nic nevědělo.

\section{Poválečná profesionalizace archeologie (1945-1991)}

Naplňování Böhmova vědeckého programu odstartovalo bezprostředně po válce terénními výzkumy realizovanými pod egidou brněnské pobočky Státního archeologického ústavu. V roce 1946 zahájil Josef Poulík († 1998) systematický výzkum kostrového pohřebiště Na pískách u Dolních Věstonic (Vachůt 2008, 178) a téhož roku provedl odkryv hradiska Kylešovicích (Poulík 1956; Šikulová 1966, 27), v jehož blízkosti se při regulaci toku Moravice v roce 1881 zachránilo torzo depotu s dvanácti stř́ibrnými denáry a soškou beránka Božího (obr. 6). O jeho znovuobjevení pro odbornou veřejnost se zasloužil Josef Schránil († 1940), který do studie o kulturních proudech v raně středověkých Čechách začlenil pasáž Střibrný „Agnus Dei“ nalezený u Komárova ve Slezsku (Schránil 1925, 175-177; Michnová et al. 2010, 114). Později na plastiku upozornil Boris Novotný († 1983) při publikaci výsledků Poulíkova výzkumu v Kylešovicích (Novotný 1962, 72-73) a znova v souvislosti s výzkumem hradiska ve Spytihněvi (Novotný 1978, 204-205), v jehož blízkosti se v roce 1938 našel babický depot, obsahující zvířecí plastiku, prsten s křištálem, nákrčníky a další předměty (Vaškových-Menoušková 2004, 111). Zkušenosti z odkryvu tzv. břetislavských hradisek uplatnil Boris Novotný v Hradci nad Moravicí, kde v roce 1956 prokázal středohradištní osídlení (Novotný 1959; Šikulová 1966, 29; Kouřil 1993).

Za podpory archeologického ústavu proběhly v letech 1952-1953 výzkumy hradisek na vrchu Landek v Ostravě-Koblově a v Chotěbuzi-Podoboře, které vedl Lumír Jisl († 1969), jehož prríchod do opavského muzea $\mathrm{v}$ roce 1947 přinesl zásadní obrat v činnosti prehistorického oddělení (obr. 7). Poválečná situace tak jednoduchá nebyla, protože nálety na konci války poškodily muzejní budovu a zasáhly i archeologické sbírky. Proto se koncem května urychleně vrátil Karel Černohorský, ačkoli byl jmenován prozatímním ředitelem brněnského zemského muzea. $\mathrm{Na}$ doporučení akademiků Jana Eisnera, Jana Filipa a Jaroslava Böhma přijal studenta prehistorie

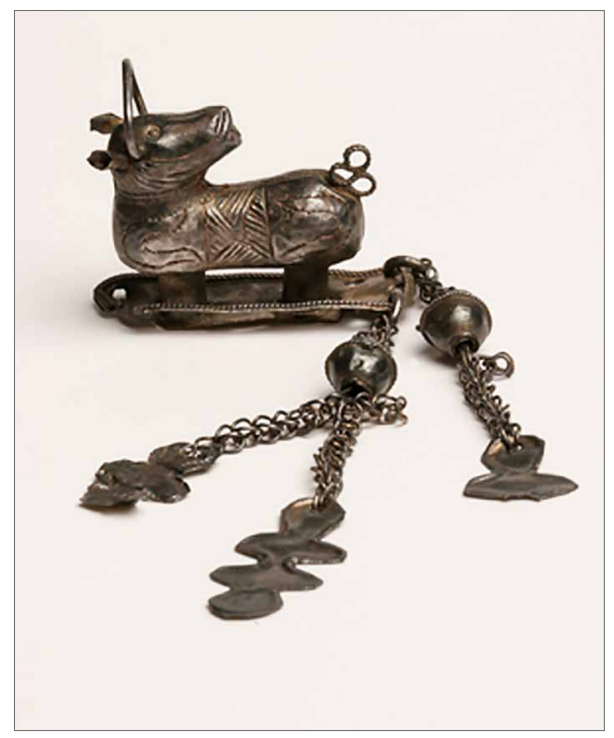

Obr. 6. Opava-Kylešovice. Stř́ibrná plastika beránka Božího. Podle Michnová-Polanský-Tomková-Tymonová 2010, 114.

Abb. 6. Opava-Kylešovice. Silberplastik des Lamm Gottes. Nach Michnová-Polanský-Tomková-Tymonová 2010, 114.

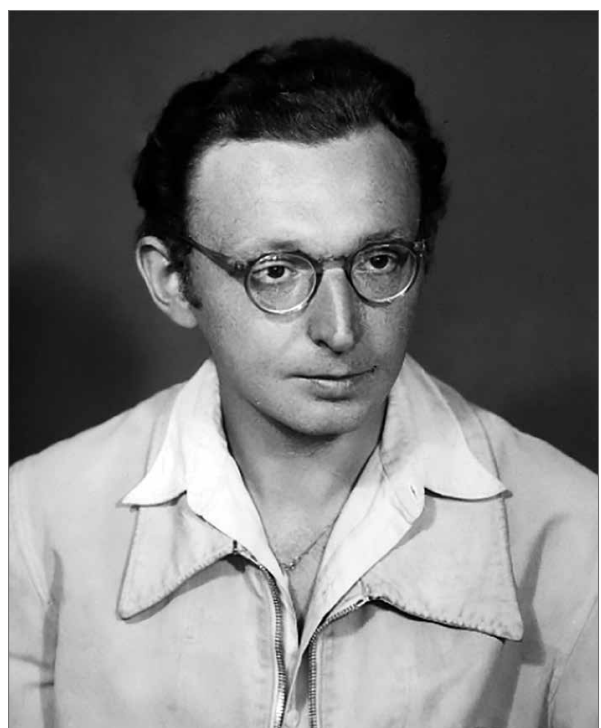

Obr. 7. Lumír Jisl. Zdroj Fotoarchiv Slezského zemského muzea v Opavě.

Abb. 7. Lumír Jisl. Quelle Fotoarchiv des Schlesischen Landesmuseums in Opava. 
a dějin umění Karlovy univerzity, na kterého čekala jen spousta práce. Sbírky doslova vykopával z trosek, revidoval válečné ztráty a zajištoval laboratorní ošetření předmětů (Jisl 1964, 128-129; Bakala 1970, 3-4; Janák 2002, 427; Sklenář 2005, 268-269). Vložené úsilí se Lumíru Jislovi bohatě vrátilo, protože se poměrně rychle seznámil s obsahem tehdy ještě několikatisícového fondu. Získané poznatky využil při prospekci v terénu a v roce 1955 při uspořádání výstavy Pravěk Slezska, která o pět let později dala základ stálé expozici (Jisl 1950a, 14-15; 1950c; 1950d; Šikulová 1969, 2-3; Bakala 1970, 5; Honková 2014, 322; Skalická-Š́íl 2014, 323).

Jislovy terénní aktivity se promítaly prakticky do všech archeologických období. V roce 1950 provedl záchranný odkryv středověkého opevnění Panská vyhlídka na štramberském Kotouči a o čtyři léta později zachraňoval nálezy z tvrziště v Heřmanovicích (Knápek 2010, 27). Zvláštní pozornost věnoval Holasovicím, kde v letech 1952 a 1954 provedl záchranný výzkum, avšak ten se vázal na eneolitickou fází osídlení (Jisl 1954-1955a). Heuristiku spojenou s historií lokality využil k sepsání studie o slovanském kmeni Holasiců, v níž podal přehled slovanského osídlení na území Opavského a Těšínského Slezska (Kouřil 1991, 97). Raně středověké nálezy z holasovického dvora, kde v roce 1948 došlo k opětnému narušování hrobů a základů kostela, ztotožnil se správním centrem piastovské kastelánie (Gradice Golensiceske), zmiňovaným v bule papeže Hadriána IV. v roce 1155 (Jisl 1952a, 34-35, 42-45, 48-49, 62). Nešlo tudíž o kmenové ústředí Holasiců, které na konci 9. století jmenoval tzv. Geograf bavorský, jak to později potvrdil Jaroslav Bakala (Bakala 1964, 110-111; Šikulová 1966, 28; Kouřil 1991a, 101-102; 1994, 48). Ve stejné době provedl zjištovací výzkum hradiska na vrchu Landek, odkud získal keramiku z 10. a 11. století, avšak na starší horizont nenarazil (Jisl 1952a, 62). Exkavaci v Chotěbuzi, označované jako Starý Těšin, prováděl v návaznosti na probíhající výzkumy varšavské archeoložky Aliny Kietlińské na Zámecké hoře (Jisl 1952a, 51; 1954a; 1957a; 1966; Kouřil 1994, 101). Časově i organizačně nejnáročnější byl systematický odkryv třiačtyřiceti mohyl ve Stěbořicích, realizovaný v letech 1952-1953, 1955 a 1961 (Jisl 1952; 1953; 1954-1955; Jelínek 1952; Vachůt 2008, 180), k jehož vyhodnocení a monografickému zpracování došlo až v roce 2013 (Kouřil-Tymonová 2013, 9).

Jislova publikační činnost (Rataj 1970, 206-222), pomineme-li četné práce věnované pravěku, se zaměřila na regionální přehledy osídlení Hlučínska (Jisl 1950), Ostravska (Jisl 1954) a Krnovska (Jisl 1957), které se staly základem syntézy pravěkých dějin Slezska a Ostravska (Jisl 1968) a také historicko-archeologické studie o česko-uherských válkách, napsané společně s opavským historikem Adolfem Turkem (Jisl-Turek 1968). Z historiografického hlediska je cenný přehled archeologického bádání ve Slezsku, který dovedl do roku 1945 (Jisl 1964), avšak tisku se nedočkala syntéza slezského pravěku a raného středověku, jejíž základ tvořil Soupis archeologických nalezišt' a nálezů ve Slezsku, opatřený relevantní literaturou a odkazy na nálezy (Janák 2002, 427; Tymonová 2005, 83).

Kromě vědecké erudice se vysokou profesionalitou vyznačovaly Jislovy organizační schopnosti, protože po odchodu Karla Černohorského do Brna v roce 1948 byl jmenován zástupcem ředitele, a přestože na funkci po dvou letech ze zdravotních důvodů rezignoval, ředitelem se stal ještě v letech 1952-1954. V následujícím roce z muzea odešel, aby se na pokyn Jaroslava Böhma ujal vedení nově zřízené opavské Expozitury Archeologického ústavu ČSAV v Brně, jejímž sídlem nadále zůstalo archeologické pracoviště. V roce 1956 byl odvolán do pražského archeologického ústavu, kde působil jako vědecký tajemník a následně jako vedoucí pravěkého oddělení (Pavelčík 1975, 361; 1975a, 46; Kouřil-Pavelčík 1985, 335; Podborský 1996, 400). Profesní i osobní zájem jej nakonec připoutal k orientalistice, s níž se prakticky seznámil v opavském muzeu při zpracování kolekce tibetského umění. V roce 1963 obhájil kandidátskou práci o orchonských Turcích, která mu zajistila mezinárodní věhlas (Bakala 1970, 4-5; Š́́ma 1970, 17; Váňa 1970, 207; Spurný 1999, 902; Janák 2002, 427; Juchelka 2019, 298-299).

Po Jislově odchodu byl vedením opavské pobočky pověřen Jaroslav Král († 2011), absolvent prehistorie a dějin umění v Brně, jehož zásluhou bylo vybudováno nové pracoviště na Bezručově náměstí, kam pobočka přsídlila v roce 1965 (Pavelčík 1981, 691; Kouřil-Pavelčík 1985, 334; Janák 1997d, 313; 2001, 822; 2002a, 313). Spolu s Václavem Burianem, Vlastou Fialovou a Karlem 
Černohorským náležel ke generaci průkopníků archeologie středověku, pro niž se v 50. letech minulého století vžilo označení historická archeologie (Měřínský 2011, 629). Inklinaci ke slovanskému období mu přinesly výzkumy v Rebešovicích a Vysočanech, na něž ve Slezsku navázaly menší akce - odkryv sídlištních jam u obce Úvalno v roce 1958 (Král 1958; 1959) nebo povrchové sběry v roce 1959 v Neplachovicích (Král 1960a, 178; Kouřil 1994, 58) a Vávrovicích (Král 1959, 178). Větší výzkum realizoval v letech 1959-1960 v Hněvošicích, kde zkoumal slovanské hroby vložené do mohyl z doby bronzové (Král 1960; 1961b, 266-266; Šikulová 1966, 29; Vachůt 2008, 180); později na tomtéž katastru objevil ještě sídliště (Král 1971). V roce 1960 sondoval na hradisku Víno u Slezských Rudoltic (Král 1958a) a o pět let později zachraňoval nálezy z výkopu pro sloup elektrického vedení v areálu Kylešovského hradiska (Král 1966). Další záchranné akce realizoval v Dolním Benešově (Král 1973a) a v Opavě, kde roku 1956 prozkoumal odpadní objekty v ulici Hrnčířské, tehdy Gottwaldově (Král 1956). O rok později vybíral jímky v Kolářské, odkud získal množství stř̌edověkého skla (Král 1961). Souběžně kopal v ulicích Ostrožné, Popské a na Vaškově náměstí (1961; 1961a), Lazebnické a Mezi trhy (Král 1961), později v Hradecké a Tyršově (Král 1974a) či v zahradě minoritského kláštera (Král 1975). V Ostravě, kde archeolog v muzeu nebyl, se v roce 1962 spolu s Vlastou Šikulovou a Jiřím Pavelčíkem podílel na výzkumu v Kostelní ulici, považovaném za první profesionálně provedenou akci (Král 1963; 1964a; Měchurová 1996, 570; Zezula 2003; Tymonová 2005, 86-87; Měchurová 2013, 186-187; Moravec 2013, 199). V roce 1967 se pracovně angažoval také v Krnově, kde zkoumal kryptu kostela sv. Martina (Kolář-Prix-Zezula 2016, 62). O výzkumech a získaných nálezech psal krátké články (Král 1973a; 1967; 1968) nebo ucelenější rozbory (Král 1971a; 1974; 1975a; 1977), jelikož se v hmotné kultuře vyznal stejně dobře jako v terénu.

V roce 1971 převzal řízení pobočky Jiří Pavelčík († 2020), za jehož vedení bylo pod expozituru převedeno archeobotanické pracoviště, vybudované Emanuelem Opravilem († 2005), jehož ke studiu paleobotaniky přiměl Josef Poulík (Opravil 1961; 1990; Janák 1995a; Čulíková 2003, 636; 2004; Sklenář 2005, 418-419; Procházka 2007, 38-40). V roce 1979 se v Opavě pod hlavičkou pražského archeologického ústavu ustavilo ještě druhé pracoviště v čele s Věrou Čulíkovou, která se zabývala zpracováním materiálu z Čech a př́iležitostně i z Opavy (Čulíková 2005). Od počátku 80. let začali pracovníci pobočky organizovat praktické pracovní semináře zaměřené na problematiku středověké hmotné kultury (Kouřil-Teryngerová 1998, 335). Ke koordinaci odborné činnosti sloužila jednání nově ustavené Severomoravské pobočky Československé společnosti archeologické př́ ČSAV (Kouřil 1981), jejímž prvním předsedou se stal Jiří Pavelčík, který přes čtvrt století prováděl systematický výzkum eneolitického hradiska v Hlinsku u Lipníka nad Bečvou (Sklenář 2005, 425; Šebela 2005, 330; Janák-Kouřil 1998, 456). Odborně byl sice vázán na pravěk, ale během prospekce zjistil v terénu řadu raně a vrcholně středověkých stanovišt' na katastrech Hradce nad Moravicí (Pavelčík 1971; 1973a; 1980), Otic (Pavelčík 1973; 1980a), Albrechtic (Pavelčík 1974; 1981), Palhance (Pavelčík 1974a; 1989b), Velkých Hoštic (Pavelčík 1978a; 1980b), Kobeřic (Pavelčík 1978), Neplachovic (Pavelčík 1989; 1990), Holasovic (Pavelčík 1989a) a Jaktaře (Pavelčík 1993a). Menší výzkum provedl v Osoblaze (1960) a další záchranné akce v historickém jádru Opavy v prostoru Horního náměstí (Pavelčík 1972) a v ulicích Masařské (Pavelčík 1978b) i Kolářské (Kouřil-Pavelčík-Teryngerová 1987). Po zrušení opavské pobočky v roce 1992 přešel do ostravského památkového ústavu a pak od roku 1995 působil ve Slováckém muzeu v Uherském Hradišti. Jednu z posledních prací, která se týkala vyhodnocení raně novověkého materiálu z výzkumu opavské spořitelny v roce 1994, publikoval spolu s Jarmilou Štěrbovou (Štěrbová-Pavelčík 1997).

Situace v opavském muzeu byla po odchodu Lumíra Jisla složitější, poněvadž získat adekvátní náhradu nebylo tak snadné. Dvě léta trvalo, než byla na místo vedoucí pravěkého oddělení přijata absolventka brněnské katedry archeologie Vlasta Šikulová († 2020), která předtím krátce působila v kyjovském muzeu (Pavelčík 1993; Podborský 1995; Juchelka 2005; 2009a; Sklenář 2005, 560). Již za studií se specializovala na raný středověk, jak předznamenala její diplomová práce o mladohradištních pohřebištích, vydaná po dvou letech tiskem (Šikulová 1958). Pracovně 
se v letech 1952-1953 podílela na výzkumu landeckého hradiska (Zezula 2017, 51) a později na popud svého předchůdce zamíŕila do Holasovic, kde v roce 1959 odkryla jedenáct hrobů a základy raně gotického kostela s jeho dřevěným předchůdcem, který datovala do 12 . století. S ohledem na pozdější výzkumy opavských památkářů (1995) a stavebně-historický rozbor Dalibora Prixe bylo stáří mladší kamenné stavby vročeno do 30.-40. let 13. století (Jisl 1964, 129; Šikulová 1966, 29; Kouřil 1994, 48; Prix v tisku; Zezula 2019, 12-17). Zjištěné poznatky vyhodnotila teprve nedávno a prezentovala je v dějinách Holasovic (Šikulová-Zezula v tisku). Nové hradištní lokality objevila v roce 1963 v trase plynovodu mezi Opavou a Krnovem na katastrech Neplachovic, Brumovic a sběrem v nedalekém Býkově (Šikulová 1964, 17-18; 1966, 29, 31); další zjistila v roce 1969 při přestavbě silnice ve Vlaštovičkách a Neplachovicích (1971a, 76). Stručný přehled slovanského osídlení s charakteristikou hlavních lokalit nastínila v popularizačním textu Památky na slovanský kmen Holasiců, vydaném za podpory ostravského památkového střediska (Šikulová 1968).

Výzkumy z období vrcholného středověku se týkaly Kotouče u Štramberka, kde v roce 1959 spolu s Jiřím Pavelčíkem a Jaroslavem Králem zkoumala opevnění na Jurově kameni včetně zaniklé vsi u tzv. Mírové studánky (Pavelčík 1960, 66; Grepl 1987, 57; Šikulová 1991b). Po Rábovu (Rabensdorf) u Horního Benešova, zdokumentovaném Karlem Schirmeisnem ve 30. letech minulého století, to byla druhá středověká osada v regionu, jejíž existenci později ověřil v terénu Vladimír Goš (Schirmeisen 1937; Goš 1979, 65; Janák-Kouřil 1991a, 210).

Další odkryvy v Opavě a Ostravě zařadily Vlastu Šikulovou k průkopníkům tzv. městské archeologie, jejíž rozvoj iniciovala poválečná výstavba. Záchrana archeologických památek se v Opavě rozběhla od poloviny 50 . let, kdy se začaly zastavovat válkou způsobené proluky v ulicích Popské, Kolářské a Mezi trhy v prostoru kolem Horního náměstí, dříve náměstí 1. máje (Šikulová 1975, 271). Při rekonstrukci severní strany zdokumentovala v roce 1963 několik objektů včetně studny, kterou datovala do doby okolo roku 1200 (Šikulová 1966a, 10). Tehdy se jí podařilo zmapovat předlokační počátky města, k jehož přeměně v institucionární město došlo mezi lety 1213-1220, což potvrdilo udělení městských práv v roce 1224 (Bakala 1969, 12-13; 1974, 22; Wihoda 1998, 27-28). O čtyři léta později sledoval obnovu jižní strany náměstí Jaroslav Král, jemuž se podařilo z vrstev 13.-14. století vyzvednout dřevěná vrata (Král 1968). Až do výzkumu dominikánského kláštera, který Vlasta Šikulová prováděla v letech 1967-1991, to byly první nálezy z centra města získané ze stratigraficky podchycených vrstev (Šikulová 1968b; 1970; 1970a; 1971, 71-72; 1972a, 121; 1973a, 90; 1974; 1978; 1982; 1990; 1991; Kouřil-Měřínský 1996, 115; Malíková-Skalická 2016, 225). Další poznatky o stavebním vývoji dominikánského kláštera přinesly výzkumy opavských památkářů v letech 1999, 2002 a 2009-2011, provedené v souvislosti s rekonstrukcí Domu umění (Kolář-Skalická-Zezula 2013). Cenná zjištění získala Vlasta Šikulová v kostele sv. Václava v Ostravě, kde v letech 1967-1968 odhalila základy staršího raně gotického předchůdce z první poloviny 14. století (Šikulová 1968a; 1970a; Měchurová 1996, 570; Zezula 2003, 8). Jeho datování pak potvrdil archeologický výzkum památkového ústavu v roce 1998 (Zezula 2003, 14-19) a rovněž stavebně-historický průzkum, jehož výsledky osvětlila studie Dalibora Prixe (Prix 2017, 29-45).

Pozitivum výzkumů Vlasty Šikulové spočívalo v pečlivé exkavaci a plavení vykopané zeminy, během nichž se podařilo zachránit množství drobných předmětů včetně mincí. Jejich prostřednictvím byly v dominikánském klášteře datovány požárové vrstvy (Šikulová 1985, 230), které obsahovaly glazovanou keramiku, z nichž nejstarší s tmavozelenou olovnatou polevou byla vročena do 30. až 60. let 13. století (obr. 8). Nálezy této původem opavské keramiky jsou známy z Kateřinek (Kouřil 1989a, 110-111) a kromě Opavy a jiných míst také z Brna, jak prokázala petrografická analýza střepů džbánu z minoritského kláštera (Procházka-Hložek 2013, 239-240). Mladší hnědě glazované fragmenty datovala Vlasta Šikulová na základě dnes nezvěstné konvice z Rešova, která obsahovala depot brakteátů z 80.-90. let 13. století (Šikulová 1991a). Numismatické nálezy chronologicky využila i v Ostravě ke stanovení zánikového horizontu staršího kostela a vzniku stávajícího gotického (Šikulová 1977; 1990, 76; 1991, 24-25; Zezula 2013b, 102). Kromě mincí zachránila i množství paleobotanického materiálu, určovaného Emanuelem Opravilem, a antropologického materiálu, analyzovaného Janou Hlavovou a Zdeňkem Tvrdým 


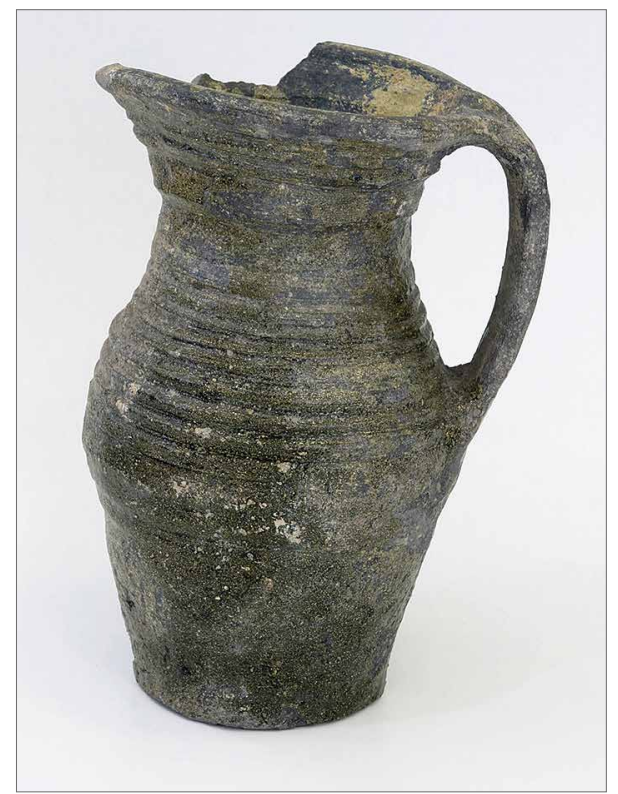

Obr. 8. Opava - dominikánský klášter. Zeleně polévaný džbán. Foto M. Tymonová.

Abb. 8. Opava - Dominikanerkloster. Krug mit grünem Überzug. Foto M. Tymonová.
(Hlavová 2001; Tvrdý 2008). Během výzkumu na náměstí Osvoboditelů (tzv. Senný trh) získala $v$ roce $1969 \mathrm{z}$ vrstev 12. a 13. století slitky olova, které podle Ladislava Pága odpovídaly složením rudě z Horního Benešova, jejíž těžbu opavským měštanům potvrdila privilegia ve 13. století (Šikulová 1971, 71; 1975, 272-273). Výzkumy $\mathrm{v}$ extravilánu městského jádra se týkaly kláštera johanitů v Zámeckém okruhu (Šikulová 1971, 72) a opavských předměstí, kde zachytila doklady hrnčířské činnosti v ulici Krnovské (Šikulová 2004, 19-21), Hradecké a v zahradě minoritského kláštera (Šikulová 1972a, 121-122; 1973a; Král 1974a; 101; 1975, 82).

$\mathrm{V}$ důsledku intenzivní výzkumné činnosti Vlasty Šikulové enormně narostl sbírkový fond, navyšovaný o materiál předávaný z archeologických ústavů, náhodné nálezy (např. z Vávrovic, Vikštejna aj.; Šikulová 1991, $25 ; 1972 ; 1973)$ a převody sbírek ze zrušených muzeí ve Vidnavě, Javorníku a Hlučíně (Tymonová 2005,83$)$. Na výstavách prezentovala nejvýznamnější nálezy - z Holasovic (1960), Opavy (1961, 1967, 1968, 1974), Ostravy (1967) nebo Cvilína (1992-1993); řada z nich byla později instalována ve stálé muzejní expozici (1981-1991). Kromě vlastních výstavních projektů participovala na rozsáhlejších výstavách - Od gotiky k renesanci $\mathrm{v}$ roce 1999 (Šikulová 1999, 227-229), Cesta ke Zlaté bule sicilské v roce 2011 (Zezula 2013a, 103) a Znameni vertikál v roce 2012 (Šikulová 2012, 119-125).

Poznatky z archeologických výzkumů osvětlila v Př́spěvku archeologie $k$ nejstarším dějinám Opavy (Šikulová 1975) nebo v Opavsku na úsvitu dějin a v období vzniku a rozvoje feudalismu (do husitských válek), sepsaném s Jaroslavem Bakalou († 2008), který archeologická zjištění promítl do historického kontextu (Šikulová-Bakala 1983). Dodnes jsou platné jeho studie o osídlení Opavska, Ostravska, Frýdecka nebo Těšínska, které pod názvem Moravskoslezské pomezí v proménách 13. věku vydali v roce 2002 Martin Wihoda a Petr Elbl.

Od 60. let a v 70. letech minulého století začali přicházet do praxe další školení profesionálové, kteří postupně obsazovali nově zřízená místa $\mathrm{v}$ muzeích. Jako jeden z prvních nastoupil v roce 1964 do novojičínského vlastivědného muzea Emanuel Grepl († 2011), původní specializací paleolitik, což mu ovšem nebránilo, aby v letech 1968 a 1970-1974 provedl zjišt'ovací výzkum hradu ve Starém Jičíně (Grepl 1987, 57; Augustinková-Knápek-Martinec edd. 2014). Na přelomu 80. a 90. let s pomocí Vratislava Janáka kopal na hradě Šostýně (Janák-Grepl 1990; 1991), kde po ukončení výzkumu až do roku 2002 dohlížel na konzervaci zdiv. Spolupracoval tehdy s kopřivnickým archeologickým kroužkem, vedeným Jiřím Tichánkem, který později zpracoval šlechtická sídla na Novojicku a Frýdecko-Místecku (Šerý-Tichánek 2003; Tichánek 2005). Drobné akce zdokumentoval Emanuel Grepl také v areálu Žerotínského zámku a ve městě u staré pošty nebo Československé spořitelny (Janák 2002, 447; Grepl 2004). Mimo to byl autorem četných výstav a archeologických expozic ve Štramberku nebo Novém Jičíně, kde participoval na oddílech věnovaných dějinám města a starojického hradu.

Na přelomu 70. a 80. let byl aktivní Kroužek řádných členů Československé společnosti archeologické v Přiboře, působící pod patronací severomoravské pobočky ČSSA. Jeho vůdčí 
osobou byl Jiří Fryč, který na základě materiálu získaného ze sběrů zveřejnil několik prací o pravěku Př́ibora, Štramberka a Kopřivnice, na což na počátku milénia navázal Jan Diviš s publikací osídlení v okolí Příbora od pravěku do raného středověku (Stabrava 2011, 77).

V Ostravském muzeu se první profesionální archeoložkou stala Lea Wiegandová, která zde působila jen krátce. V roce 1971 nechala geodeticky zaměřit hrad Přerovec (Wiegandová 1972), v následujícím roce provedla menší záchranný výzkum kostela sv. Václava v Ostravě (Wiegandová 1973) a větší vykopávky realizovala v letech 1971-1973 v areálu Slezskoostravského hradu (Wiegandová 1972a; 1973a; Měchurová 1996, 571; 2009, 38-39; 2011, 78-79). Také její nástupce Rostislav Janošík († 2016) nepracoval v muzeu dlouho. Odborně se zajímal o tvrziště v Řepištích u Vratimova a v letech 1976-1977 provedl zjišt'ovací výzkum na vrchu Landek, kde zjistil osídlení z 8. a 9. století. Výsledky odkryvů publikoval pouze informativně (Janošík 1977; 1978), což napravil Pavel Kouřil, který na hradisku provedl revizní výzkum v roce 1998 (Kouřil 1991, 100; 1994, 38; 1996, 48; Zezula 2017, 51).

V bruntálském muzeu, založeném v roce 1907, působil v letech 1974-1978 Svatopluk Bříza († 2020), který se staral o záchranu archeologických památek v Bruntále a Krnově. V roce 1974 provedl zjištovací výzkum kostela ve Starém Městě, který souvisel s původní lokací Bruntálu (Bříza 1974; 1991), což v roce 2002 prokázal výzkum Jiř́ho Kohoutka († 2007) z brněnského ústavu památkové péče (Kohoutek 2004) a v roce 2011 výzkum opavských památkářù (Kiecoň-Zezula 2014). Další akce realizoval v letech 1976 a 1981, kdy jako stavební technik dohlížel nad výkopy inženýrských sítí v areálu bruntálského zámku (Bříza 1978, 111; Tymonová 2011, 26). V polovině 70. let provedl zjištovací výzkum v krnovském kostele sv. Ducha a o několik let později v objektu krnovského zámku (Bříza-Kolář-Zezula 2016, 64). V emeritním věku aktivně působil v Městském muzeu v Krnově, kde uspořádal řadu archeologických výstav a zpracovával archeologické nálezy, které získával od nejrůznějších nálezců. Zprávy o nich publikoval v Přehledech výzkumů a v roce 2006 v brožuře Pravěké památky Krnovska (Bříza 2006), dovedené až do pozdního středověku. Společně s Markétou Janákovou zpracoval Dějiny archeologického bádání na Krnovsku (Bř́za-Janáková 2016).

Do historie bádání se v 70. letech zapsal články o panských sídlech na Jesenicku také Vladimír Goš († 2020) z tehdejšího mohelnického a později šumperského muzea, pod nějž v letech 1963-1996 spadalo jesenické muzeum, zrušené roku 1960 s okresem Jeseník (Fišer 1996, 60; Tymonová 2005, 86). Když byly v první polovině 60. let z Olomouce do Šumperka převedeny jesenické sbírky, obsahující nálezy z Kaltenštejna, Rychleb, Javorníka, Skorošic, Adolfovic, Vladimír Goš toho využil a o řadě z nich napsal studie (Goš 1976; 1977; 1978; Goš-Rychlý 2002; 2016). Sám pak v letech 1975-1976 provedl záchranný výzkum vodní tvrze v Jeseníku (Goš 1977a; 1981; Kouřil-Kováčik-Prix-Wihoda 2007, 240-241).

Na Javornicku spočívala archeologická práce na Zdeňku Brachtlovi († 1999), absolventu učitelského dějepisu na univerzitě v Olomouci, který v roce 1979 nastoupil do tehdejší jesenické pobočky šumperského muzea, po jejímž osamostatnění byl v roce 1996 jmenován ředitelem (Goš 1999, 576; Janák 1999, 168). Zpočátku prováděl povrchové sběry na Jesenicku, Osoblažsku nebo Opavsku, ale později se zaměřil na drobná opevněná sídla, která zkoumal na základě geofyzikálního průzkumu (Brachtl 1989; Brachtl-Dohnal 1986; 1996). V letech 1989-1994 provedl zjištovací výzkum tvrziště v Javorníku-Vsi (Brachtl 1989; 1992a; 1993; 1994, 41; 1996; 1997a; 1997b; 1999a; Brachtl-Gronychová 1993; 1993a); v roce 1994 zachraňoval nálezy v nedalekém Pustém zámku v Račím údolí (Brachtl 1997, 201) a o rok později v javornickém románsko-gotickém kostele sv. Kř́že (Brachtl 1997b), kde ve výzkumu v roce 2015 pokračovala olomoucká Archaia (Kováčik-Dudková-Lafková 2016). Další záchrannou akci podnikl v roce 1992 při sanaci amatérských výkopů na hradě Kaltenštejně (Brachtl 1996b) a v letech 1995-1996 zkoumal Jánský vrch (Brachtl 1997c, 202; 1998; Tymonová 2015, 944-945), v jehož areálu v roce 2002 zdokumentovali výkopy inženýrských sítí pracovníci olomouckého památkového ústavu (Dehnerová-Šlézar 2013). Spolu s Milanem Rychlým, který nedávno dokončil studium archeologie magisterskou prací o jesenických hradech (Rychlý 2018), provedl ve druhé polovině 90 . let 
zjištovací výzkum hradu Pleče na Šumpersku (Rychlý-Brachtl 1991) a záchranný průzkum domu v historickém jádru Javorníku (Brachtl-Rychlý 1999a). Poslední Brachtlovy aktivity se zaměřily na mapování zaniklých důlních děl ve Starohoří, kde spolupracoval s geologem Josefem Večeřou (Brachtl-Večeřa 1999). Získané nálezy evidoval a prezentoval na četných výstavách nebo v regionálním tisku (Brachtl 1985; 1993; 1999).

Hlavní výzkumná činnost ve slezském regionu spočívala na opavském pracovišti Archeologického ústavu ČSAV v Brně, personálně posíleném v roce 1978 o Pavla Kouřila, který do Opavy přestoupil ze slavkovského muzea (Sklenáŕ 2005, 312; Janák 2010, 42), a na Vratislavu Janákovi, jenž o čtyři léta později přišel z vyškovského muzea (Sklenář 2005, 252-253). Bádání se díky tomu zaměřilo na problematiku slovanského osídlení, vrcholně středověká opevněná sídla a města. Stěžejním z hlediska osídlení v době hradištní se stal systematický výzkum hradiska v Chotěbuzi-Podoboře, zahájený Pavlem Kouřilem v roce 1978, k němuž v polovině 80 . let přibyly záchranné akce v Hradci nad Moravicí, na nichž participoval také Vratislav Janák. Během exkavace se podařilo zjistit půdorysnou dispozici valového opevnění a zachycena byla situace související s nejstarší fází kamenného hradu (Janák-Kouřil 1998; 456, tam odkazy na literaturu; Kouřil 1993; Kouřil-Měřínský-Plaček 1994, 134). Výsledky výzkumů na přelomu 80. a 90. let završily studie podávající přehled o hradištním osídlení v českém Slezsku a na severovýchodní Moravě (Kouřil 1989b; 1992b; Janák-Kouřil 1991).

Paralelně s průzkumy slovanských lokalit se rozvíjelo studium drobných středověkých opevnění (DSO), označovaných jako tzv. hrádky, za něž jsou pokládány fortifikované útvary s převážně dřevohlinitou zástavbou, stojící mimo vesnice (Kouřil-Měřínský-Plaček 1994, 127). Základní kompendium v podobě soupisu šlechtických sídel Moravy v monografii Hrádky a tvrze na Moravě, publikované Vladimírem Nekudou a Josefem Ungrem v roce 1981, zahrnovalo řadu slezských lokalit, avšak mnohé z nich postrádaly podrobnějšś informace o lokalizaci, půdorysné dispozici nebo datování; některé v něm nebyly uvedeny vůbec (Nekuda-Unger 1981). Jejich identifikace spojená s dokumentací a zjištovacími průzkumy byla hlavním úkolem mapování sídel na Opavsku (Dolní Životice, Závada; Kouřil 1982; 1983a), Frýdecko-Místecku a Jablunkovsku (Sviadnov-Štandl, Lipina, Řepiště, Lubno, Karpentná, Hrádek ve Slezsku, Jablunkov-Návsí, Janovice; další v Čeladné, Bílé nebo Staříči; Kouřil 1984; 1985; 1990a; 1992c; Janák 1995; Janák-Kouřil 1998, 455; Kouřil-Žáček 1986, 103-127; 1987), Karvinsku (Stonava; Kouřil 1989) a Novojicku (Lubina, Kateřinice, Hodslavice, Polouvsí, Jeseník nad Odrou, Velké Albrechtice; Kouřil 1989c). Vedle menších fortifikací byly studovány vrcholně středověké hrady z hlediska jejich kolonizačního významu (Měřínský 1981; 1991; Měřínský-Plaček 1991; 1991a; Kouřil 1992a; 1993a; Kouřil-Měřínský-Plaček 1994). Záchranné a zjištovací odkryvy proběhly v areálu Hukvald (Kouřil-Žáček 1981), Frýdku (Kouřil 1983b), Šostýna (Janák-Grepl 1990; Kouřil 1992) nebo Bruntálu (Kouřil 1989b). Formou dílčích studií byl zpracován Luginsland (Kouřil-Plaček 1985), Zátor, Quingburg a Kobrštejn (Kouřil-Plaček 1986; 1986a), Moravský Beroun (KouřilPlaček 1987), Edelštejn a Leuchtenštejn (Kouřil-Plaček 1988), Vartnov (Kouřil 1988) a čtveřice hradů v okolí Vrbna pod Pradědem - Freudenštejn, Fürstenwalde, Pustý zámek a Rabštejn (Kouřil-Plaček 1988b). Záchrana archeologických památek probíhala také ve městech, kde většinou reagovala na destruktivní vliv stavební činnosti (Janák-Kouřil 1991a, 201). Zpravidla se jednalo o dohledy spojené s odkryvy kulturních souvrství nebo jímek v Opavě (Horní náměstí, ulice Na valech, Hrnčířská, Kolářská: Janák-Kouřil 1984; Kouřil-Teryngerová 1987; Kouřil-Pavelčík-Teryngerová 1987; Kouřil 1989a; 1991), Karviné (Kouřil 1983), Ostravě (Janák-Kouřil 1987), Bruntále, Novém Jičíně nebo v Příboře (Kouřil 1990; Janák-Kouřil 1991a, 210-211; 1998, 455). Systematicky byl Vlastou Šikulovou zkoumán pouze dominikánský klášter, což ještě více prohloubilo nepoměr mezi pramennou základnou Opavy vůči ostatním městům v regionu.

Nepříznivý stav výzkumu přetrvával v oblasti zaniklých středověkých vsí, jelikož osídlení tohoto typu, až na výše zmíněný Rábov u Horního Benešova a zaniklou ves u Mírové studánky na Kotouči u Štramberka, nebylo sledováno vůbec, což v podstatě platí dodnes. Při hodnocení je potřeba vzít v úvahu poměrně nízké personální obsazení, široký záběr výzkumné činnosti 
a značný rozsah území. Do toho se promítala i úroveň tehdejší dokumentační techniky a organizování dalších aktivit, jako byly kupř́íkladu výstavní prezentace v Karviné-Fryštátě (Janák 1989), Brušperku (Janák 1992) nebo v Novém Jičíně (Janák 1997a).

\section{Archeologické bádání po roce 1989}

V organizaci archeologické práce došlo k zásadním změnám v důsledku transformace Akademie věd České republiky - proběhla delimitace Archeologického ústavu ČSAV v Brně a v roce 1992 byla zrušena opavská pobočka, která byla v následujícím roce převedena pod Památkový ústav v Ostravě (Kouřil-Teryngerová 1994, 51; Janák-Kouřil 1998, 456; Procházka 2007, 40; Zezula 2019, 40). Archeologické oddělení vedené Pavlem Kouřilem setrvalo i nadále v budově na Bezručově náměstí, kde zůstal archiv, knihovna a laboratoř. $\mathrm{V}$ polovině 90 . let odešel z ústavu Jiř́ Pavelčík a Vratislav Janák se posléze přesunul na Slezskou univerzitu, kde v roce 1992 vznikl Ústav historie a muzeologie, pod nímž začal o tři léta později fungovat Archeologický semináŕ, transformovaný nejprve na Archeologické oddělení Ústavu historických věd a v roce 2009 na samostatný Ústav archeologie Filozoficko-přírodovědecké fakulty. Po Praze a Brnu tak vzniklo třetí univerzitní archeologické pracoviště, které se zpočátku orientovalo na archeologii středověku (Janák 1997). Odborná praxe studentů probíhala na hradisku v Chotěbuzi a na výzkumech převážně organizovaných brněnskou pobočkou archeologického ústavu. V poslední době také na akcích neziskové organizace Archaia Olomouc, o. p. s., ustavené v roce 2006, která se soustředila na výzkumy v oblasti Jesenicka (Jeseník - Masarykovo náměstí: Kováčik-Veselá 2006; Zlaté Hory - náměstí Svobody: Kováčik-Schön 2011; Javorník-ves, kostel Nelezení sv. Křŕže: Kováčik-Dudková-Lafková 2016), Ostravska (Starý Bohumín: Kováčik-Schön-Zezula 2008; Velká Polom - tvrz: Kováčik-Tobiaszová 2011) a Frýdecko-Místecka (Frýdek - Na Blatnici, Na Půstkách: Cheben-Kováčik-Moník 2008). V roce 2014 participovalo univerzitní pracoviště na záchranném výzkumu v Osoblaze (obr. 9) a o rok později na průzkumu kostela Nalezení sv. Křiže v Javorníku. Pracovníci olomoucké Archai se také podílí na výuce předmětů zaměřených na středověk a na zpracování bakalářských i diplomových prací, které dlouhá léta vedl Vladimír Goš, vystř́ídaný Peterem Kováčikem a Markétou Tymonovou.

Archeologické oddělení, které zůstalo pod Památkovým ústavem v Ostravě, přejmenovaným v roce 2003 na Národní památkový ústav, ú. o. p. v Ostravě, se orientovalo na výzkumy v Opavě, jež na počátku 90. let prováděla Hana Teryngerová. Při záchranných odkryvech v suterénech a zadních traktech domů na Dolním náměstí, realizovaných v letech 1992-1993, získala první informace o stratigrafii v této části města (Teryngerová 1997; 1999). Další výzkumy s nálezy dřevěných konstrukcí zjistila $\mathrm{v}$ ulici U pošty a v Ostrožné, odkud kromě kostěných artefaktů pocházel mariánský poutní odznak původem z Cách (Teryngerová 1996; 1999; 2000; 2002; Kouřil-Teryngerová 2002); dva další exempláře se později našly v bývalé ulici Radniční na rohu Ostrožné a Popské a v ulici Holubí (Chlebec 2014, 13; Marethová 2012, 58; Zezula 2019, 85). V roce 1994 z jímky v Masařské ulici vyzvedla soubor gotického nápojového skla, který byl interpretován jako doklad přítomnosti krčmy či kupecké činnosti (Teryngerová 1995, 33; 1999a; Břečková 2017; 259; Kiecoň 2001, 88). V dominikánském klášteře v roce 2002 odkryla společně s Pavlem Stabravou polygonální závěr kostela (Malíková-Skalická 2016, 225). Řadu záchranných akcí realizovala v Hlučíně, kde v roce 1999 společně s Pavlem Stabravou vykopala zemnici v Úzké ulici (Stabrava-Teryngerová 2001), v roce 2000, a poté 2004, sondovala v areálu zámku (Tryngerová 2001) a o rok později v prostoru městského opevnění (Teryngerová 2002). Další situace zjistila v ulicích Hrnčířské, Lidické, Ostravské ad. V letech 2006-2007 provedla s Terezou Krasnokutskou záchranný výzkum před klimkovickým zámkem, kde odkryla zbytek mostu (Krasnokutská-Teryngerová 2008). V roce 2007 v ostravské Puchmajerově ulici zkoumala část morového hřbitova, založeného v roce 1585 (Teryngerová 2008). Před odchodem do památkového ústavu v Ústí nad Labem provedla v roce 2008 zjištovací výzkum v areálu zámku v Kunčicích nad Ostravicí, zaniklého požárem v roce 1999 (Teryngerová 2009). 


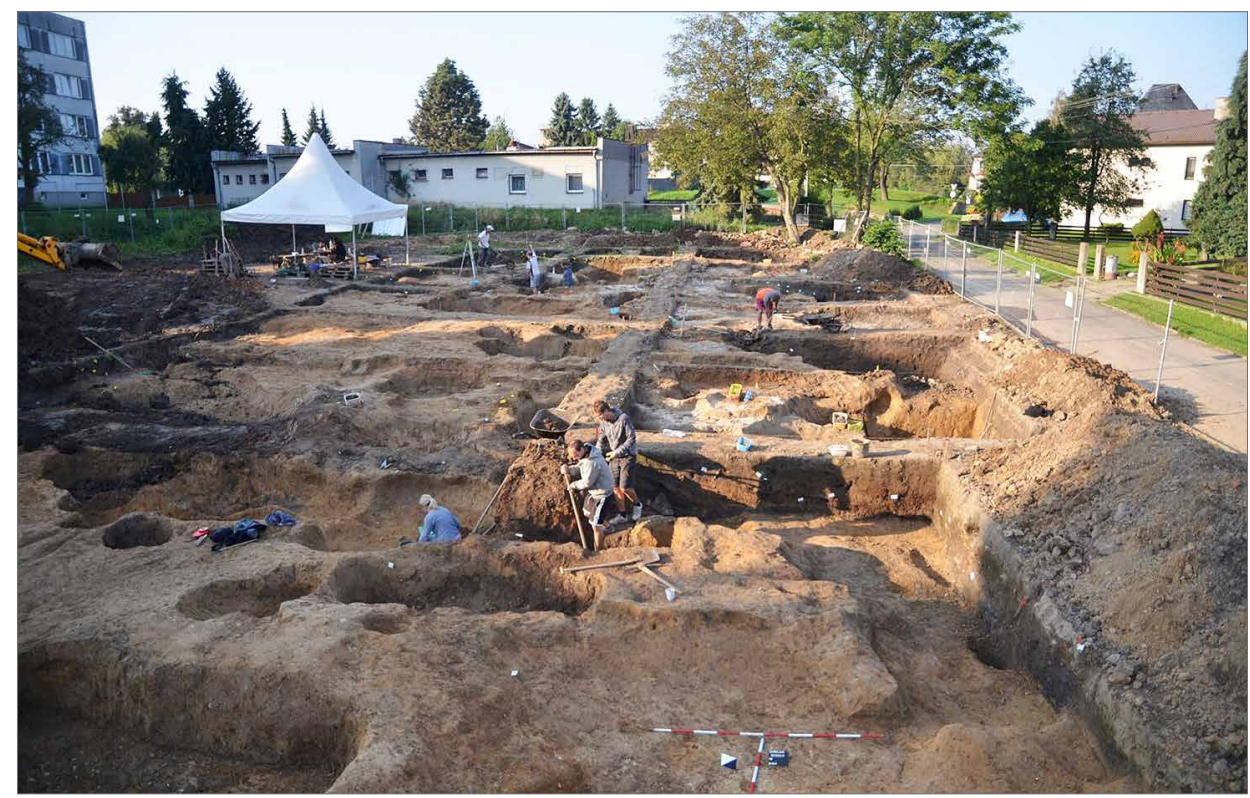

Obr. 9. Osoblaha. Záběr na výzkum Ústavu archeologie FPF Slezské iniverzity v Opavě a společnosti Archaia Olomouc, o. p. s. Foto Kateřina Papáková.

Abb. 9. Osoblaha. Aufnahme der Grabung des Instituts für Archäologie der Philosophisch-Naturwissenschaftlichen Fakultät der Schlesischen Universität in Opava und der gemeinnützigen Gesellschaft Archaia Olomouc. Foto Kateřina Papáková.

Většina výzkumů, které provedl Pavel Stabrava, se týkala pravěku. Do středověku spadala záchrana pozůstatků loretánské kaple před průčelím kostela v dominikánském klášteře v roce 1996 a o dva roky později průzkum filiálního kostela sv. Kateřiny v Kelči (Stabrava 1999). Několik záchranných odkryvů realizoval v Hradci nad Moravicí (Stabrava 1999a; 2000; 2005), v roce 2001 v areálu zámku ve Staré Vsi pod Ondřejníkem na Frýdecko-Místecku (Stabrava 2002) a o rok později ve Štáblovicích na Opavsku (Stabrava 2003). Po odchodu do muzea Novojičínska, kde nyní působí jako kurátor a vedoucí archeologického pracoviště, provedl záchranný výzkum v domě na náměstí Sigmunda Freuda v Př́iboře (Stabrava 2014). Mimo to napsal do publikace o lese na Kravařsku pojednání o středověkých lesních řemeslech a sekerách. Odborně se podílel na zbudování muzejních expozic v Novém Jičíně a v Muzeu Šipka ve Štramberku (FrühbauerováStabrava 2017).

Koncem 90. let a po roce 2000, kdy nebývale stoupl počet záchranných výzkumů, docházelo k postupnému personálnímu posílení archeologického oddělení památkového ústavu (Michal Zezula, Jiř́i Juchelka, Jindřich Hlas, Marek Kiecoň, František Kolář, Barbara Marethová aj.). $\mathrm{S}$ přibývajícím počtem výzkumů úměrně stoupal i objem poznatků, které bylo možno komparovat s předchozími zjištěními a současně s novými informacemi sdílenými s ostatními centry tzv. městské archeologie, jako jsou Praha, Brno nebo Olomouc. Díky tomu se podařilo definovat základní tematické okruhy studia vývoje městských aglomerací, především v Opavě a Ostravě, ale také u menších měst, jako jsou Bruntál, Hradec nad Moravicí, Krnov, Horní Benešov a další. Těžiště archeologického bádání zůstalo tradičně v Opavě, kde se pozornost zaměřila na předlokační a lokační vývoj města (Kiecoň-Zezula 2004) v návaznosti na výpověd' historických, kartografických, ikonografických a dalších pramenů, které umožnily sledovat utváření komunikační sítě v návaznosti na parcelaci města (Zezula-Kiecoň-Kolář 2007; Kolář-Zezula 2011; 2014a), nejstarší dřevohlinitou zástavbu (Kiecoň-Zezula 2005; Kolář 2006; 2010a; Skalická-Marethová 
2013; 2014; Kolář-Zezula 2014; Marethová 2018), sanitární infrastrukturu (Kiecoň-Zezula 2007; Zezula 2008), církevní architekturu (Prix-Zezula 2002; 2002b), městské opevnění nebo mlýnský náhon u Fortenského mlýna (Juchelka 2003; Kiecoň-Zezula 2005a; Kolář 2005; 2007; Kolář-Kaniová-Rosová-Zezula 2008).

Výsledky dlouholetých výzkumů městského fortifikačního systému zpracoval Michal Zezula, od roku 2012 ředitel Národního památkového ústavu, ú. o. p. v Ostravě, v katalogu Opavské hradby (Zezula 2013, 28-35). Na mapování průběhu městského opevnění na severovýchodní straně města se dílčím způsobem podílela také Archaia Olomouc, o. p. s., pod vedením Petera Kováčika, který v roce 2007 spolu s památkovými archeology provedl zjištovací výzkum v místech bývalé městské tržnice a v prostoru tzv. Dolního pivovarského dvora. Na to v letech 2008-2010 navázal výzkum v bývalém opavském pivovaru, přestavěném následně na obchodní středisko Breda \& Weinstein (Kováčik-Malík-Zezula 2008). Historii objektu, v němž se dříve vařilo pivo, prezentovala publikace s př́značným názvem Opavský pivovar, v níž byly zpracovány archeologické doklady související s výrobou a konzumací piva (Zezula 2015). Na poznání průběhu jihovýchodního úseku hradeb v místech bývalého opavského hradu participovalo v letech 2015-2017 také Archeologické pracoviště Slezského zemského muzea, které se zaměřilo na výzkumy v Müllerově domě, jehož západní obvodovou zed' tvořila městská hradba ze 13. století. Objekt sám původně sloužil jako hradní kuchyně, později přestavěná na sýpku a posléze na obydlí správce (Kolář-CejpováKaniová-Prix-Rosová 2018, 171-175). Interpretaci nálezové situace podal v širším historickém kontextu katalog S knižaty u stolu. Kuchyně a kultura stolování na vévodských dvorech v Opavě a Ratiboři, vydaný u příležitosti stejnojmenné výstavy (Korbelářová-Zezula 2018). Skromnější formu měl katalog Předměty vyprávějí, v němž byly v roce 2012 publikovány nálezy z opavského pivovaru a Radniční ulice, instalované na stejnojmenné výstavě (Vojkůvová-Zezula 2012). U př́ležitosti dalších výstavních akcí vznikly katalogy Opavský zámek (Miketová-Müller 2012) a Opavské hradby (Kolář 2013), které prezentovaly archeologické nálezy v Obecním domě, kde na čas doplnily stálou expozici Cesta města, která byla otevřena v roce 2010 (Zezula 2019, 32). Po Slezském zemském muzeu s expozicí Slezsko je to v pořadí druhá stálá expozice ve městě.

Řadu výzkumů provedlo opavské oddělení Památkového ústavu ve spolupráci s Ostravským muzeem, v němž v letech 1993-2003 působila na částečný úvazek Zdeňka Měchurová (Sklenář 2005, 375), která kromě zpracovávání sbírek a pořádání výstav sepsala historii bádání na Ostravsku do počátku 90. let minulého století; publikovala také řadu stř̌edověkých nálezů uložených v archeologickém fondu (Měchurová 1994; 1995; 1996; 2013). Aktualizovaný přehled výzkumné činnosti ve městě, dovedený do roku 2002, podal Michal Zezula na základě výzkumů v kostele sv. Václava, na Kostelním a Masarykově náměstí, v ulicích Střelniční nebo 28. října (Zezula 2003; 2017a). Spolupráce památkářů s Ostravským muzeem pokračovala i za kurátorky Johany Střílkové (Kolář-Stř́lková 2005) a po roce 2005 za Zbyňka Moravce (Zezula-MoravecKočár-Sůvová 2009), který se podílel na většině výkopů v Kostelní ulici, na Masarykově náměstí, v ulicích Pivovarské, Hradní, Muzejní nebo 28. října (Moravec 2007; 2007b; 2009; 2010; 2012a; 2013; 2013a). Nejvýznamnější nálezy z historického jádra města zveřejnil v roce $2007 \mathrm{v}$ katalogu k výstavě Tvár̆ středověké Ostravy (Moravec 2007a) a v roce 2011 v reprezentativní publikaci k výstavě Jan Lucemburský. Král, který létal. Moravsko-slezské pomezi v kontextu středoevropského prostoru, vydané u př́ležitosti výročí královy korunovace v bazilice sv. Víta v Praze (Moravec 2011). Další památky zpracoval společně s Michalem Zezulou v př́spěvku Archeologické prameny: Každodenni život středověkého měštana (Moravec-Zezula 2017), který vyšel v knize vydané k výročí 750 let založení Ostravy pod názvem Ostrava. Počátky a vývoj středověkého města (Antonín et al. 2017).

Několik výzkumů proběhlo také ve Frýdku, kde Zuzana Břízová zdokumentovala v rámci úprav prvního nádvoří zámku v roce 1995 zasypaný hradní př́íkop, zachycený pracovníky muzea již v letech 1975 a 1981 (Tymonová 2016, 419). V ulici Hluboké a na staveništi obchodního střediska Kaufland mezi Masarykovou třídou a ulicemi Hlubokou a Na Blatnici zachytili archeologové z Národního památkového ústavu v Ostravě v letech 2003-2004 středověké kulturní 
vrstvy, odpadní objekty s kachlovou deponií a zbytek dřevohlinitého domu (Juchelka 2004; 2006, 233-234; Kolář 2006a; 236-237; Tymonová 2016, 420). Přehled nejstaršího osídlení Frýdecko-Místecka pak shrnul Michal Zezula v dějinách Frýdku-Místku (Zezula 2014).

Záchranné akce památkového ústavu se týkaly také průzkumů staveb sakrální architektury a s nimi souvisejících funerálních objektů, které byly vyvolány zpravidla stavebními rekonstrukcemi. Kromě již zmíněného opavského dominikánského a minoritského kláštera proběhly výzkumy v kostele Nanebevzetí Panny Marie v Branticích na Bruntálsku (Prix-Zezula 2000), kde se později přesunuly na místní zámek (Kolář-Skalická 2012). Odkryv v kostele sv. Martina v Bohušově (Prix-Zezula 2003) byl doveden do podoby monografie (Kozák-Prix-Zezula edd. 2011) a v kapli sv. Michala v Bruntále (Kolář 2009) zapadal do sumy dohledů nad výkopy ve městě, kde byly na centrálním náměstí objeveny pozůstatky dřevohlinité zástavby z přelomu 14. a 15. století (Kiecoň 2005). Cenná zjištění poskytly vykopávky v kostele Nanebevzetí Panny Marie v Budišově nad Budišovkou (Kolář 2010), kostele sv. Benedikta v Krnově-Kostelci, zpracovaném taktéž monograficky (Zezula ed. 2009) a v kostele Povýšení sv. Kř́iže v Karviné 1 - Fryštátě (Kiecoň-Zezula 2019).

V př́ipadě Krnova byly výsledky stavebněhistorických a archeologických výzkumů shrnuty do katalogu Krnov: historie, archeologie, vydaného u př́ležitosti stejnojmenné výstavy (Kolář-Prix-Zezula 2016). Archeologické výzkumy proběhly dále v Horním Benešově na Mírovém náměstí, kde byly identifikovány pozůstatky středověké a raně novověké zástavby (Kiecoň-PrixZezula 2006). Ve Velkých Heralticích byla objevena středověká pec z přelomu 12. a 13. století, spojovaná s předlokační osadou (Krasnokutská-Zezula 2008; Zezula 2013a; 2019, 21, 101); s lokací na přelomu 13. a 14. století pak souvisely objekty dřevohlinité zástavby zjištěné v místní usedlosti (Kiecoň-Krasnokutská-Zezula 2008). Záchranné akce se uskutečnily i v Holasovicích, kde bylo v letech 2011 a 2016 zjištěno další mladohradištní pohřebiště se čtrnácti hroby z druhé poloviny 10. až počátku 11. století, situované na okraji obce u soutoku Heraltického potoka s Opavicí (Hlas-Marethová 2017). Nepublikované výzkumy v areálu hospodářského dvora, zmiňované Michalem Zezulou v disertační práci, sice jednoznačné doklady o spojení Holasovic s ústředím piastovské kastelánie nedoložily, zato nastínily stavební vývoj církevní stavby, jejíž starší fáze z konce 12. století by mohla korespondovat s přemyslovskou anexí Holasicka a mladší z 30. či 40. let 13. století s urbanizací Bruntálu, Opavy nebo Hlubčic (Zezula 2019, 16, 25-26), jak to interpretují zmíněné dějiny Holasovic (Rosová a kol. v tisku).

Menší záchranný výzkum byl realizován v roce 2002 při stavbě rozhledny v extravilánu hradu Fürstenwalde na katastru Ludvíkova pod Pradědem (Malík 2014). S problematikou těžby polymetalických rud, která je v regionu dlouhodobě sledována (Krut’a 1958; Bakala 1972; Novák-Štěpán 1984; 1985; 1986; 1987; Fojt-Večeřa 2000; Večeřa 2002; 2014; Večeřa-Večeřová 2010), souvisel nález v Suché Rudné, kde opavští památkáŕi v letech 2012-2013 odkryli dobývku s pozůstatky promývacího zařízení na rýžování zlata, dendrochronologicky vročenou do období přelomu let 1186/1187 až 1234 (Ernée-Hrubý-Malý-Tomášek-Valkony 2014, 102; Večeřa-Malík-Zezula 2014, 75, 80). Stopy po těžbě zlata objevili v roce 2006 pod zříceninou hradu Edelštejn na katastru Zlatých Hor také pracovníci olomoucké Archaii, kteří dlouhodobě mapují pozůstatky důlní činnosti (Kováčik-Schön 2011; Moník-Plaštiaková 2007; Moník-Plaštiaková-Kováčik 2007).

Nové poznatky prezentovali archeologové z památkového ústavu nejen tiskem nebo na výstavách, nýbrž také na odborných konferencích či seminářích. V roce 2010 uspořádali v Opavě devátý ročník mezinárodní konference Forum Urbes Medii Aevi na téma Středověké město a jeho předměstí. Další odborné setkání, které proběhlo v roce 2017 v Ostravě u příležitosti výročí první písemné zmínky o městě, se zabývalo tématem Středověká města a jejich zakladatelé. Kromě pořádání odborných setkání se památkářům podařilo vyřešit problém s uložením archeologických nálezů, čítajících v roce 2009 téměř tři tisíce beden. Národní památkový ústav je tehdy chtěl jednorázově předat Slezskému zemskému muzeu, a když byl odmítnut, vybudoval v roce 2015 depozitář vlastní, umístěný ve vedlejší budově ostravského ředitelství. 
Slezské zemské muzeum se s nedostatkem depozitárních prostor potýkalo léta, a proto uložení sbírek bylo vzhledem k jejich počtu a havarijnímu stavu budovy v ulici Komenského více než tristní. Ǩada nálezových souborů byla dislokována „kde se dalo“, což komplikovalo zpracování zvláště po roce 2000, kdy vstoupil v platnost zákon č. 122/2000 Sb., o ochraně sbírek muzejní povahy. O rok později archeologický fond převzala autorka tohoto článku, která při převádění inventářů do elektronické podoby zjistila, že sbírka čítá o několik set tisíc položek více, než bylo vykazováno. U řady prrírůstkových zápisů nebyl uveden ani přibližný počet předmětů, což značně komplikovalo inventarizaci. Za tohoto stavu se požadavek památkového ústavu jevil jako nereálný. Navzdory veškerým obtížím se podařilo většinu nálezových celků zkompletovat, očíslovat, přeadjustovat a po kontrole uložit do nového depozitáře. Týkalo se to především více než statisícového celku z dominikánského kláštera, jehož zpracování se v roce 2013 ujaly nové kurátorky Pavla Skalická a Hana Malíková v rámci zpracování interních grantů Středověká a raně novověká Opava ve světle archeologických pramenů I a II. Jejich snahou bylo, aby ve spolupráci s autorkou výzkumů Vlastou Šikulovou připravily podklady pro sepsání nálezových zpráv, kterých byla v archivu archeologického pracoviště uložena necelá desítka (Malíková-Skalická 2016, 223). Tento záměr v roce 2015 utlumila rekonstrukce Müllerova domu a stěhování sbírek do objektu Herbaria v Arboretu Nový dvůr. Následné personální změny v roce 2019 přinesly osamostatnění archeologického pracoviště, v jehož čele stanul Jiří Juchelka, který do programu nově ustaveného oddělení prosadil záchrannou činnost.

Další změny ve struktuře archeologických institucí nastaly v roce 2003, kdy zásluhou Pavla Kouřila, od roku 2008 ředitele Archeologického ústavu AV ČR v Brně, došlo k obnovení opavské pobočky, která $\mathrm{v}$ souladu s původní koncepcí pokračovala $\mathrm{v}$ systematickém výzkumu slovanského osídlení, panských sídel a skrze záchrannou činnost i měst. Výsledkem studií zveřjněných do poloviny 90. let byla syntéza Slovanské osídlení českého Slezska, která shrnula poznatky z průzkumů hradisek (Víno u Slezských Rudoltic, Hradec nad Moravicí, Opava-Kylešovice, Ostrava-Landek a Chotěbuz-Podobora), pohřebišt' (Hněvošice, Hradec nad Moravicí, Malé Hoštice, Rozumice, Stěbořice) a téměř dvou desítek vesnických osad (Kouřil 1994). Od druhé poloviny 90 . let byly publikovány další práce, které osvětlily formování sídelních struktur v severním předpolí Moravské brány od počátků slovanské přítomnosti do konce hradištního období s využitím historických pramenů (Kouřil 1996; 1996a; 1997; 1998; 1998a; 2001; 2005; 2005a; Wihoda 1997; 1997b; 1999; 2005; 2006; 2012; Hašek 2001; Měřínský 2006, 57; Procházka 2009, 121, 138; Kouřil-Tymonová 2013; Kouřil-Gryc 2014; Kouřil-Procházka 2018, 66-70), konfrontovaných s výsledky přírodovědných expertiz (Opravil 1994; Hašek 2001; Nývltová Fišáková 2004; 2007; 2008; 2010; 2012; Svobodová-Bartoš-Nývltová Fišáková-Kouřil 2015; Kouřil 2017). Bádání výraznou měrou obohatily neočekávané objevy - nález velkomoravského bojovnického hrobu v Zámecké ulici v Hradci nad Moravicí v roce 2000 (Kiecoň 2001a, 207; Kouřil 2004), odkryv pohřebiště se sedmnácti hroby na katastru Malých Hoštic v roce 2008 (Juchelka 2009; 2010; Kouřil 2009) nebo výzkum raně středověkého opevnění v Opavě-Kylešovicích v letech 2015-2016 (Kouřil-Gryc 2018). Před detektoráŕi se z hradiska Víno podařilo zachránit několik set kovových nálezů, mezi jinými i jedenáct ostruh s háčky (Kouřil 2017, 59-60), které doložily př́tomnost jezdecké elity v severním předpolí Moravské brány ve druhé polovině či třetí třetině 8. století. Jedna byla nalezena i na předhradí chotěbuzského hradiska (Kouřil 2007, 5; 2017, 58; Kouřil-Gryc 2014a, 229-230), jehož výzkum přinesl celou řadu dalších zjištění o konstrukci opevnění, vnitřní zástavbě a osídlení (obr. 10).

Zapojení hradisek na české straně hranice do soustavy hornoslezských opevnění podala syntéza Slezsko v časech raného středověku, zveřejněná v prvním díle publikace Slezsko v dějinách českého státu (Antonín-Koư̌il-Prix 2012). Aktuální stav poznání slovanského osídlení v období 8. až 11. století přinesla studie Czech Silesia in the Early Middle Ages, zveřejněná v Přehledech výzkumů (Kouřil-Gryc 2019). Stručné výsledky bádání na hradisku v Chotěbuzi-Podoboře byly spolu s nejvýznamnějšími nálezy prezentovány ve výpravném katalogu $\mathrm{k}$ výstavě Velká Morava a počátky křestanství, která v letech 2014-2015 proběhla v Brně, Praze a Bratislavě 


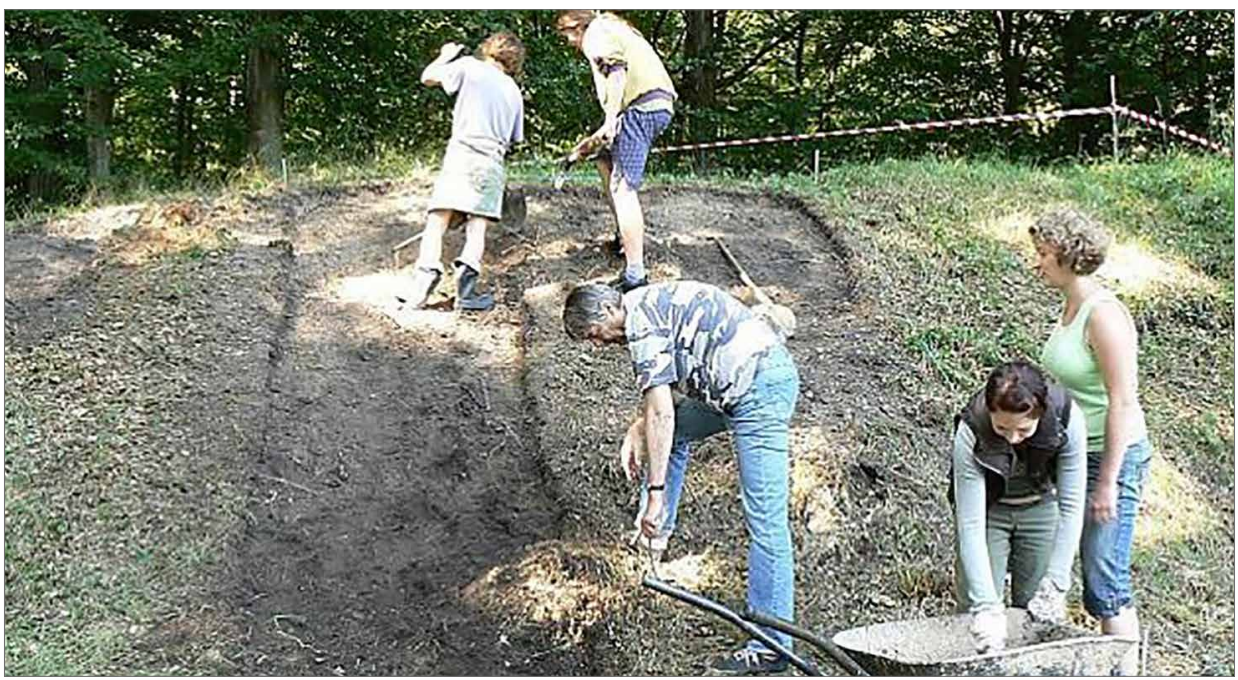

Obr. 10. Chotěbuz-Podobora. Pracovní snímek z výzkumu na prvním předhradí s vedoucím výzkumu Pavlem Kouřilem a Janou Gryc. Foto M. Tymonová.

Abb. 10. Chotěbuz-Podobora. Arbeitsfoto von der Grabung auf der ersten Vorburg mit Grabungsleiter Pavel Kouřil und mit Jana Gryc. Foto M. Tymonová.

(Kouřil-Gryc 2014a). Přímo v terénu byly zkoumané objekty představeny prostřednictvím rekonstrukcí postavených v areálu stavební repliky Archeoparku, zpř́stupněné v roce 2005 na akropoli hradiska. Při jejím úpatí byla v roce 2016 vybudována vstupní budova s expozicí, instalovanou a spravovanou Muzeem Těšínska.

Do průzkumu vrcholně středověkých opevnění se od poloviny 90 . let aktivně zapojili Dalibor Prix a Martin Wihoda (Kouřil-Prix 1995; Kouřil-Wihoda 1996; 1999; Kouřil-Prix-Wihoda 1997), jejichž dlouholetá spolupráce vyústila v synteticky koncipovanou monografii Hrady českého Slezska, která přinesla komplexní vyhodnocení téměř třiceti vrcholně středověkých fortifikací z hlediska historie, archeologie, dějin umění a dalších relevantních disciplín. Mezioborový prŕstup umožnil, aby byly otázky vzniku, funkce a vývoje hradních organismů řešeny v širším historickém kontextu (Kouřil-Prix-Wihoda 2000). S př́íchodem nového milénia se bádání zaměřilo na problematiku wüstehubského dominia (Kouřil-Wihoda 2001; 2002; 2004), hradní architekturu (Kouřil-Měřínský-Plaček 2006) a interetnické poměry (Kouřil-Wihoda 2003), které se staly hlavním tématem jednání 34. mezinárodni konference archeologie středověku, konané v roce 2002 v Opavě. Další publikační výstupy obsahovaly historicko-archeologické analýzy drobných středověkých opevnění v Adolfovicích (Kouřil-Prix-Wihoda 2005), Ondřejovicích (Kouřil-Prix-Wihoda 2006), Skorošicích (Kouřil-Prix 2008), Hrádku (Kouřil 2008a), Hradci (Kouřil-Prix 2011) a Bohušově (Kouřil-Prix-Wihoda 2019). Miroslav Plaček do odborné literatury uvedl ještě tvrz v Bartošovicích na Novojicku a v Bělé na Ostravsku (Plaček 2006).

V souvislosti s výzkumem měst byl ve Vlastivědných listech publikován přehled nejdůležitějších archeologických zjištění (Koư̌il 2000), jehož rozšířená a podrobnější verze s archeologicky nastíněným obrazem středověkého města vyšla v dějinách Opavy (Kouřil 2006). Okrajově byla dříve sledována také církevní architektura, a to skrze kostel v Pelhřimovech na Bruntálsku (Kouřil-Prix 1991).

$\mathrm{V}$ rámci materiálových studií byl analyzován soubor mladohradištní grafitové keramiky z hradisek na české i polské straně (Kouřil 1998b), nálezy z husitského období z hradu Javorník (Kouřil 2009a), sekery ze slezských hradů (Kouřil 2002a) a jako jednotlivosti železný meč 
z Heřmanovic (Kouřil 1986, 515), Menasova ampule z rychlebského souboru (Kouřil 2002) nebo bronzová hlavice palcátu z Přerovce (Kouřil 2003). Ve studii Etnické trojmezi byly představeny opavské nálezy v souvislosti s transformací ve 13. století (Kouřil-Wihoda 2003, 86-101).

K poznání středověké hmotné kultury přispěly také práce ostatních archeologů, které se zaměřily na nálezy z hradů Cvilín a Javorník (Tymonová 2010; Brachtl 1992), střredověké sklo ze Cvilína a Opavy (Sedláčková 2004; 2004a; Břečková 2017), výrobky z kovů a kosti z Landeka a Kaltenštejna (Brachtl 1995; Měchurová 1996a; 2004), kamnářské výrobky z Opavy, Starého Bohumína, Ostravy a slezských hradů (Krasnokutská 2005; Kováčik-Veselá 2009; Tymonová 2009; 2011; 2012; 2015; 2016; 2017; Hložek-Tymonová 2018; Moravec 2019a), středověké plastiky z Javorníka, Opavy a dalších lokalit (Brachtl 1996a; Měchurová 1994; 1995; Měřínský-Procházka 2010, 11), dětské hračky (Malíková 2016) nebo militaria a součásti zbroje z Rychleb, Stěbořic, Opavy, Javorníka a Starého Jičína (Brachtl-Goš-Vašíček 1989; Knápek 2008; 2010; 2011; Tymonová-Žákovský 2012; Žákovský 2013; 2018). Řada středověkých nálezů byla představena ve výše uvedených publikacích nebo výstavních katalozích.

Předložený obraz vývoje archeologického bádání ukazuje, že navzdory všem obtížím, s nimiž se záchrana hmotných památek v dlouhodobě opomíjeném regionu potýkala, byla vybudována funkční struktura archeologických institucí, jejíž pilíře tvoří v současnosti muzea, archeologický ústav, památkový ústav, univerzita a nezisková Archaia Olomouc. Jejich součinnost nejenže umožňuje naplňování principů archeologické památkové péče a záchranu materiálního dědictví obecně, ale přispívá také $\mathrm{k}$ rozvoji disciplíny samotné a především k prohlubování archeologického poznání, bez něhož se dnes historie těžko obejde.

\section{Literatura}

AL SAHEB, J., 2004: Řeka Ostravice a její role v dějinách Frýdlantu nad Ostravicí, Sborník Státního okresního archivu ve Frýdku-Místku 5, 79-96.

ANTONÍN, R. et al., 2017: Ostrava. Počátky a vývoj středověkého města. Ostrava.

- 2012: Slezsko v časech raného středověku. In: Slezsko v dějinách českého státu I. Od pravěku do roku 1490 (Jirásek, Z., ed.), 95-163. Praha.

AUGUSTINKOVÁ, L.-KNÁPEK, A.-MARTINEC, P., 2014: Hrad Starý Jičín. Ostrava.

BAKALA, J., 1964: Holasické pomezí v 11. a 12. století - Holasice Grenze im 11. und 12. Jahrhundert, ČSM B 13, 105-117.

- 1964a: Sjednocení opavského muzejnictví. In: 150 let Slezského muzea (Duda, J., ed.), 55-71. Ostrava.

- 1969: Holasická provincie a formování opavského vévodství - Die Holasitser Provinz und die Gestaltung des Tropauer Herzogtums, ČSM B 18, 9-23.

- 1970: Lumír Jisl a vědecké bádání ve Slezsku, ČSM B 19, 1-8.

- 1972: Počátky těžby kovů v Nízkém Jeseníku a vznik Horního Benešova, ČSM B 21, 161-179.

- 1974: Počátky města Opavy. Zvláštní číslo k 750. výročí města Opavy, ČSM B 23, 3-24.

- 2002: Moravskoslezské pomezí v proměnách 13. věku. Výbor z článků a studií (Wihoda, M.-Elbl, P., edd.). Brno.

BAKALA, J.-ŠIKULOVÁ, V., 1983: Opavsko na úsvitu dějin a v období vzniku a rozvoje feudalismu (do husitských válek). In: Přehled dějin Opavska. Soubor příspěvků k dějinám opavského okresu od pravěku do současnosti, 20-35. Opava.

BARTHOLOMÄUS, F., 2011: Viktor Karger als Kustos des Teschener Museums, Těšínský muzejní sborník 4, 225-248.

BLAŽEK, J., 2003: Z dějin archeologického ústavu za okupace, AR LV, 581-601.

BORÁK, M.-GAWRECKI, J., 1992: Nástin dějin Těšínska. Ostrava.

BÖHM, J., 1926: Slezsko v době předhistorické, Vlastivědný sborník slezský 2, 15-31.

BRACHTL, Z., 1985: Katalog archeologické sbírky zámeckého muzea v Javorníku, Informační zpravodaj členů Sm. pobočky Čs. spol. archeologické při ČSAV, duben, 29-38. 
- 1989: Geofyzikální a topografický průzkum středověkých lokalit na katastru města Javorníku (okr. Šumperk) - Geophysikale und topographische Untersuchung mittelalterlicher Lokalitäten im Kataster der Stadt Javorník (Bez. Šumperk), PV 31, 86-87.

- 1992: Archeologické nálezy z areálu zámku v Javorníku, Informační zpravodaj členů Sm. pobočky Čs. spol. archeologické při ČSAV, květen, 42-46.

- 1992a: Středověké tvrziště v Javorníku-Vsi, okr. Šumperk - Eine mittelalterlichen Festenstätte in Javorník-Ves (Bez. Šumperk), VVM XLIV, 487-498.

- 1993: Třetí výzkumná sezóna v Javorníku-Vsi (okr. Šumperk) - Die dritte Grabungssaison in Javorník-Ves (Bez. Šumperk), PV 36, 79.

- 1993a: Výstava o jesenických hradech a drobných fortifikacích v Německu, Informační zpravodaj členů Sm. pobočky Čs. spol. archeologické při ČSAV, srpen, 79-80.

- 1994: Z dějin muzejní práce na Jesenicku, SM 68, 31-45.

- 1995: Kovové a kostěné předměty z hradu Kaltenštejna. Fond muzea v Jeseníku a zámeckého muzea v Javorníku. Šumperk.

- 1996: Další etapa zjištovacího výzkumu v Javorníku-Vsi (okr. Šumperk) - Fortsetzung der Versuchsgrabung in Javorník-Ves (Bez. Šumperk), PV 37, 81.

- 1996a: Keramická středověká plastika koníčka z Javorníku-Vsi - Mittelalterliche Tonplatik - ein Pferdchen aus Javorník-Ves, VVM XLVIII, 287-290.

- 1996b: Záchranný výzkum na hradě Kaltenštejn (o. Černá Voda, okr. Šumperk) - Rettungsgrabung an der Burg Kaltenstejn (Bez. Šumperk), PV 37, 81-82.

- 1997: Javorník (okr. Šumperk). Pustý zámek, Račinské údolí u Javorníku. Drobné opevněné sídlo. Vrcholný středovek (14. stol.). Záchranný výzkum - Pustý zámek u Javorníku (Bez. Šumperk). Račinské údolí bei Javorník. Kleine befestigte Siedlung. Hochmittelalter (14. Jh.). Rettungsgrabung, PV 1993-1994, 201-202.

- 1997a: Javorník (okr. Šumperk). Tvrziště. 14.-15. stol. Zjištovací výzkum - Festungsstatte. 14.-15. Jh. Vorlaufige Sondierung, PV 1993-1994, 203.

- 1997b: Javorník (okr. Šumperk). U kostela sv. Kř̌́že. Drobné opevněné sídlo. Středověk. Zjištovací výzkum - Javorník-Ves (Bez. Šumperk). Bei der Kirche sv. Kříže. Kleine befestigte Siedlung. Mittelalter. Forlaufige Sondierung, PV 38, 203-204.

- 1997c: Javorník (okr. Šumperk). Zámek Jánský vrch. Středověk - novověk. Zjištovací výzkum - Schloss Jánský vrch. Mittelalter - Neuzeit. Vorlaufige Sondierung, PV 38, 202.

- 1998: Zjištovací výzkum na zámku Jánský Vrch v Javorníku, okres Jeseník, Badania archeologizcne na Górnym Śłąsku i ziemiach pogranicznych w 1995 roku, 134-136.

-1999: Hesla č. 128-135. In: Od gotiky k renesanci. Výtvarná kultura Moravy a Slezska 1400-1550. Svazek IV. Opava (Chamonikola, K., ed.), 229-231. Brno.

- 1999a: Javorník (okr. Jeseník). Tvrziště. Středověk. Drobná hliněná plastika. Zjištovací výzkum - Befestigte Siedlung. Mittelalter. Keramische Kleinplastik. Rettungsgrabung, PV 40, 409.

BRACHTL, Z.-DOHNAL, J., 1986: Středověké tvrziště v Heřmanovicích, okres Bruntál (Výsledky archeologického a geofyzikálního průzkumu), ČSM B 35, 30-39.

- 1996: Geomagnetické měření v prostoru hrádku v Račím údolí u Javorníku - Geomagnetische Messungen im Raum des Burgwalls im Krebsgrund bei Javorník (Jauernig), CB 5, 353-356.

BRACHTL, Z.-GOŠ, V.-VAŠÍČEK., 1989: Unikátní palná zbraň z Rychleb, SM 57, 47-48.

BRACHTL, Z.-GRONYCHOVÁ, M., 1993: Druhá sezóna výzkumu drobného středověkého opevnění v Javorníku-Vsi (okr. Šumperk) - Zweite Grabungsaaison einer kleinen mittelalterlichen Befestigung in Javorník-Ves (Bez. Šumperk), PV 35, 96-97.

- 1993a: Výzkum středověkého tvrziště v Javorníku-Vsi (okr. Šumperk) - Erforschung einer mittelalterliche Feste in Javorník-Ves (Jauernig-Dorf, Bez. Šumperk), PV 34, 94-95.

BRACHTL, Z.-RYCHLÝ, M., 1999a: Javorník (okr. Jeseník). Dům č. 403, ul. Míru, středověk - Haus Nr. 404, Míru Strasse, das Mittelalter, PV 40, 328-329.

BRACHTL, Z.-VEČĚ̌A, J., 1999: Terénní archeologický průzkum středověkých důlních děl na Zlatohorsku (okr. Jeseník), PV 39, 518-520. 
BRAUN, E. W.-ČERNOHORSKÝ, K., 1925: Průvodce výstavou habánských a vyškovských fajansí. Opava. BŘEČKOVÁ, K., 2017: Středověké sklo z Opavy II. Nálezy skla z archeologických výzkumů na ulici Masařská 6, Pekařská - Kolářská a Mnišská - Mezi Trhy, PA CVIII, 257-289.

BŘÍZA, S., 1974: Archeologický výzkum ve Starém Městě, Vpřed 47, 3.

- 1991: Staré Město. Průvodce městem, Náš domov 4, 45-46.

- 1978: Záchranný výzkum Bruntál - zámek 1976 (okr. Bruntál) - Rettungsgrabung Bruntál - Schloss 1976 (Bez. Bruntál), PV 21, 111.

BŘÍZA, S.-JANÁKOVÁ, M., 2016: Historie archeologického bádání na Krnovsku. Krnov.

BŘÍZA, S.-KOLÁŘ, F.-ZEZULA, M., 2016: Krnov a jeho archeologický výzkum. In: Krnov - historie, archeologie (Kolář, F.-Prix, D.-Zezula, M., edd.), 58-67. Ostrava.

ČAPSKÝ, M., 2011: Hospodářský obraz moravsko-slezského pomezí v době vlády Jana Lucemburského. In: Král, který létal. Moravsko-slezské pomezí v kontextu středoevropského prostoru doby Jana Lucemburského (Majer, D. et al., edd.), 39-50. Ostrava.

ČERNOHORSKÝ, K., 1927: Museum Matice opavské a jeho sbírky. Zvláštní otisk z „Památníku Matice Opavské 1877-1927“. Opava.

- 1928: Jak se vyráběly výškovské fayense. Vyškov.

- 1941: Moravská lidová keramika. Praha.

- 1964: Pozoruhodný nález válcovitého poháru v Opavě, ČSM B 13, 118-126.

ČIŽMÁŘ, M., 2005: Hans Freising - 100 let od narození, Pravěk NŘ 15, 479-481.

ČULÍKOVÁ, V., 2003: K sedmdesátinám RNDr. Emanuela Opravila, CSc., AR LV, 636-649.

- 2004: Půlstoletí ve službách archeologie. K sedmdesátinám archeobotanika RNDr. Emanuela Opravila, CSc. - A Fifty-year Service to Archaeology: The 70th Birthday of RNDr. Emanuel Opravil, CSc, Ve službách archeologie 5, 6-8.

- 2005: Pozdně středověké odpadní jímky na Drůbežím trhu v Opavě: pepř, kmín, cibule, černucha a další rostliny (Archeologický výzkum v r. 2005) - Late medieval cespits in Drůbeží trh (Poultry Market) in Opava: pepper, caraway, onion, devil in the bush and other plants (archeological research in 2005), ČSZM B 60, č. 1, 1-46.

DEHNEROVÁ, H.-ŠLÉZAR, P., 2013: Archeologický výzkum na východním předhradí státního zámku Jánský Vrch - Archaeological research on the east bailey of the state castle Jánský Vrch, ČSZM B 62, $115-128$.

DVOŘÁKOVÁ, E.-POLÁCH, R.-ZEZULČÍK, J., 2016: Architekti a stavitelé města Nového Jičína. Nový Jičín.

ENS, F., 1837: Das Oppaland, oder der Troppauer Kreis, nach seinen geschichtlichen, naturgeschichtlichen, bürgelichen und örtlichen Eigenthümlichkeiten IV. Wien.

ERNÉE, M.-HRUBÝ, P.-MALÝ, P.-TOMÁŠEK, M.-VALKONY, J., 2014: Raná exploatace exogenních akumulací zlata na Českokrumlovsku - Early exploitation of the secondary gold deposits by Český Krumlov, Acta rerum naturalium 16, 85-108.

FIŠER, Z., 1996: Městské muzeum v Javorníku ve Slezsku, VVM XLVIII, 60-62.

FOJT, B.-VEČĚ̌A, J., 2000: Zlaté Hory ve Slezsku - největší rudní revír v Jeseníkách - Zlaté Hory in Silesia - the biggest ore district in the Jeseniky Mts., Czech Republic, Acta Musei Moraviae, Scientiae Geologicae 85, 3-45.

FOLPRECHT, J., 1996: O prvních archeologických výzkumech na Landeku, Těšínsko 3, 23-25.

FRÜHBAUEROVÁ, O.-STABRAVA, P., 2017: Nová expozice ve Štramberku, Vlastivědný sborník Novojičínska 67, 151-152.

GAVRECKI, D. a kol., 2003: Dějiny českého Slezska 1740-2000. Díl I. Opava.

GOLEC, J.-BOJDA, S., 1995: Wiktor Karger. In: Słownik biograficzny ziemi cieszyńskiej 2, 86-87. Cieszyn.

GOŠ, V., 1976: Soubor železných předmětů a zbroje z hradu Rychleb ve Slezsku - Der Fundkomplex eisener Gegenstände und eines Spangenharnisches von der Burg Rychleby (Reichenstein), VVM XXVIII, 293-300.

- 1977: Archeologický výzkum tvrzí na Jesenicku - Archäologische Untersuchung der Festungen in Region Freiwaldau, AH 2, 33-36. 
- 1977a: Záchranný výzkum tvrze v Jeseníku (okr. Šumperk) - Rettungsgrabung einer Feste in Jesenik (Bez. Šumperk), PV 20, 71-72.

- 1978: Středověké tvrze na Jesenicku, SM 36, 50-55.

- 1979: Zaniklá osada Rabendorf (Rábov) u Horního Benešova - Die Ortswüstung Rabendorf bei Horní Benešov, VVM XXXI, 64-66.

- 1981: Vodní tvrz v Jeseníku. Archeologický výzkum nejstarší fáze a problematika tvrzí na Jesenicku, ČSM B 30, 227-246.

- 1999: Zemřel Mgr. Zdeněk Brachtl (21. 5. 1953 - 12. 4. 1999), AR LI, 576.

GOŠ, V.-RYCHLÝ, M., 2002: Unikátní kamenina z hradu Kaltenštejna u Černé Vody, SM 42, 43-44.

- 2016: Středověká kamenina na Jesenicku - Medieval pottery in Jeseníky Mountains, VVM LXVIII, 324-328.

GREPL, E., 1989: Vývoj archeologického bádání v okrese Nový Jičín, Vlastivědný sborník okresu Nový Jičín 39, 56-58.

- 1991: Archäologische Rettungsgrabung der Burgruine Šostýn (Gemeinde Kopřivnice, Bez. Nový Jičín), PV 33, 58.

- 2004: Záchranný archeologický průzkum nadzemní části septiku Žerotínského zámku v Novém Jičíně, Vlastivědný sborník okresu Nový Jičín 54-55, 176.

HAŠEK, V., 2001: Geofyzikální prospekce na výšinném hradisku v Chotěbuzi-Podoboře u Českého Těšína - Geophysical Prospection at Hillfortress in Chotěbuz-Podobora near Český Těšín. In: Archaeologia mediaevalis Moravica et Silesiana I/2000 (Měřínský, Z., ed.), 217-230. Brno.

HLAS, J.-MARETHOVÁ, B., 2017: Mladohradištní pohřebiště na katastru obce Holasovice, okr. Opava Late hillfort burial ground at the cadastre of the village of Holasovice, Opava county, Pravěk NŘ 25, 271-290.

HLAVA, M., 2017: Jaroslav Böhm a Lothar Zotz. Kapitola z dějin Státního archeologického ústavu - Jaroslav Böhm und Lothar Zotz. Ein Kapitel aus der Geschichte des Staatlichen Archäologischen Instituts, ASČ 21, 17-45.

- 2019: Zlatý věk uničovské archeologie. Mizzi Manethová a Muzeum v Uničově. Olomouc.

HLAVOVÁ, J., 2001: Antropologický rozbor kosterního materiálu z dominikánského kláštera v Opavě. Rkp. nepubl. diplomové práce, ved. práce doc. E. Drozdová, Ph.D., Brno.

HLOŽEK, M.-TYMONOVÁ, M., 2018: Středověké kachle s motivem lovu nalezené v českém Slezsku a jejich provenience - In Tschechisch-Schlesien entdeckte Kacheln mit dem Motiv der Jagd und ihre Provenienz, AH 43, 511-535.

HONKOVÁ, B., 2014: Heslo IV/7.3. Lumír Jisl. Průvodce výstavou Pravěk Slezska. In: Země a její muzeum. Slezské zemské muzeum a muzejní tradice českého Slezska (Š́1, J. a kol.), 321-322. Opava.

CHEBEN, M.-KOVÁČIK, P.-MONÍK, M., 2008: Frýdek-Místek (k. ú. Frýdek, okr. Frýdek-Místek). Ulice Na Blatnici a Na Půstkách. Středověk, novověk. Město. Záchranný výzkum, PV 49, 397.

CHLEBEC, P., 2014: Opava and its Position on the Medieval Route between Moravia and Prussia According to the Archaeological Sources, Dějiny a město 3, 6-17.

JANÁK, V., 1989: Archeologická výstava v Karviné, VVM XLI, 356-357.

- 1992: Archeologická výstava v Brušperku, Těšínsko 1, 29.

- 1995: Osídlení vrchu „Štandl“ u Frýdku-Místku v posledním tisíciletí před změnou letopočtu - Besiedlung des Berges „Štandl“ bei Frýdek-Místek im letzten Jahrtausend vor der Zeitwende, ČSZM B 44, 97-106.

- 1995a: Životní výročí Emanuela Opravila, Pravěk NŘ 3, 313-314.

- 1997: Archeologické pracoviště na Slezské univerzitě, AR XLIX, 717-718.

- 1997a: Dvacet let od úmrtí Viktora Kargera, Pravěk NŘ 6, 307-308.

- 1997b: Kotouč ve středověku. In: Kotouč. Hora Olivetská (katalog výstavy), 13-15. Nový Jičín.

- 1997c: Nedožité jubileum Lumíra Jisla, Pravěk NŘ 6, 304-307.

- 1997d: Sedmdesáté páté narozeniny Jaroslava Krále, Pravěk NŘ 6, 313-314.

- 1998: Přelom i pokračování (Archeologie v českém Slezsku v 80. a první polovině 90. let), AR L, 455-463.

- 1999: Za Zdeňkem Brachtlem, Acta historica et museologica 4, 168-169. 
- 2001: Jaroslav Böhm a slezská archeologie, AR LIII, 772-779.

- 2001a: Osmdesáté narozeniny dr. Jaroslava Krále, AR LIII, 822.

- 2002: Lumír Jisl a organizace archeologické práce ve Slezsku, Pravěk NŘ 11, 427-431.

- 2002a: Osmdesát let Jaroslava Krále, Pravěk NŘ 11, 437-438.

- 2002b: Šedesáté narozeniny dr. Emanuela Grepla, Pravěk NŘ 11, 447-449.

- 2010: Docent Pavel Kouřil šedesátiletý, Vlastivědné listy Slezska a Severní Moravy 36, č. 2, $42-44$.

JANÁK, V.-GREPL, E., 1990: První etapa záchranných prací na hradě Šostýně u Kopřivnice (okr. Nový Jičín) - Erste Etappe der Rettungsarbeiten auf der Burg Šostýn in Kopřivnice (Bez. Kopřivnice), PV 1987, 69-70

JANÁK, V.-KOUŘIL, P., 1984: Narušený stř̌edověký objekt v Opavě - Gestörtes mittelalterliches Objekt in Opava (Bez. Opava), PV 32, 60.

- 1987: Nález lidských kostí na Slezské Ostravě (Bez. Ostrava) - Fund von Menschenknochen in Slezská Ostrava (Bez. Ostrava), PV 29, 72-73.

- 1991: Osídlení Štramberku a jeho nejbližšího okolí v době hradištní, Vlastivědný sborník okresu Nový Jičín 47, 66-78.

- 1991a: Problémy a úkoly archeologie v českém Slezsku a na severovýchodní Moravě, ČSZM B 40, $193-219$.

- 1998: Přelom i pokračování (Archeologie v českém Slezsku v 80. a první polovině 90. let - Wandepunkt sowie Fortsetzung (Die archeologie im tschechischen Schllesien wähend der 80. und der I. Hälfte der 90. Jahren), AR L, 455-464.

JANEČEK, L., 2017: Uč ctíti sebe sama: Počátky muzejnictví na Ostravsku. Rkp. magisterské práce ÚHV FF MU v Brně, ved. práce doc. Ing. František Svoboda, Ph.D., Brno.

JANOŠÍK, R., 1977: Archeologická zajímavost nad soutokem Odry s Ostravicí, Oderský mlýn, Zpravodaj vodohospodářské skupiny povodí Odry 1, 26-28.

- 1978: Hradiště Landek nad soutokem Odry s Ostravicí, Oderský mlýn, Zpravodaj vodohospodářské skupiny povodí Odry 1, 14-16.

JELÍNEK, J., 1952: Slovanský kostrový materiál ze Stěbořic u Opavy - Matériaux ostéologiques Slaves des Stěbořice près d'Opava, ČSM B 2, 20-28.

JEŽ, R.-PINDUR, D., 2010: Hradní vrch v Těšíně. In: Těšínsko v proměnách staletí. Sborník přednášek z let 2008-2009 k dějinám Těšínského Slezska (Jež, R.-Pindur, D., edd.), 185-200. Český Těšín.

JISL, L., 1950: Hlučínsko v pravěku, Český lid 5, 1-4.

- 1950a: Průvodce výstavou „Pravěk Slezska“. Opava.

- 1950b: Př́́spěvek k poznání kulturních styků Slezska ve středověku, Slezský sborník 48, 102-103.

- 1950c: Výstava „Pravěk Slezska“, AR 2, 115-118.

- 1950d: Výstava „Pravěk Slezska“. Slezské muzeum v Opavě - 21. května až 9. července 1950, Slezský sborník 48, 411-412.

- 1952: Slovanské mohylové pohřebiště ve Stěbořicích - Tumuli slaves à Stěbořice près d'Opava, okr. Opava, ČSM B 2, 6-20.

- 1952a: Slovanský kmen Holasiců ve světle archeologických nálezů - Der slawische Stamm der Golensizi im Lichte der Bodenfunde, ČSM B 2, 33-64.

- 1953: Slovanské mohyly ve Stěbořicích u Opavy, AR V, 32-53.

- 1954: Nárys pravěku Ostravska. In: Z dějin vesnice Kozlovic na Ostravsku 1294-954 (Jisl, L.-Ulčák, L. a kol., edd.), 13-17. Ostrava.

- 1954a: Zpráva o výzkumu hradiště „Starý Těšín“ v r. 1952, Zprávy Okresního muzea v Českém Těšíně, duben (nestránkováno).

- 1954-1955: Výzkum slovanských mohyl ve Stěbořicích r. 1953, ČSM B 4, 65-80.

- 1954-1955a. Záchranný výzkum neolitických jam z Holasovic u Opavy roku 1953, ČSM B 4, 36-43.

- 1957: K nejstaršímu osídlení krnovského okresu, Krnovsko I, 1-5.

- 1957a: Zpráva o výzkumu hradiště „Starý Těšín v r. 1954, Zprávy okresního muzea v Českém Těšíně 13 (nestránkováno).

- 1961: Po dávných stopách slovanství. In: Pravda o Slezsku, 5-6. Opava.

- 1966: Burgwall „Starý Těšín“ (Moraviae), Investiations archéologiques en Tschécoslovaquie, Prague, 241. 
- 1964: Počátky archeologického bádání ve Slezsku a opavská muzea. In: 150 let Slezského muzea (Duda, J., ed.), 121-129. Ostrava.

- 1965: Žárové pohřebiště lidu popelnicových polí v Úvalně u Krnova - Die Begräbnisstätte des Urnengräbervolkes in Úvalno bei Krnov. Zvláštní otisk z ČSM B 14, 7-20.

- 1968: Slezsko a Ostravsko v pravěku a rané době dějinné. In: Ostravsko do roku 1848. Kapitoly k historickému vývoji Slezska a Ostravska od pravěku k revolučnímu roku 1848 (Grobelný, A. a kol., edd.), 10-29. Ostrava.

- b. d.: Soupis archeologických nalezišt’ a nálezů ve Slezsku. Nepubl. rkp. ulož. v Archivu archeologického oddělení Slezského zemského muzea v Opavě.

JISL, L.-TUREK, A., 1953: Ostravsko za česko-uherské války ve světle písemných pramenů i archeologických nálezů - Das Ostrauer Land während des böhmisch-ungarischen Krieges im Lichte der Urkunden und archäologischen Funde, ČSM B 3, 1-24.

JUCHELKA, J., 2003: Objev úpravy břehů mlýnského náhonu v Opavě, Sborník Památkového ústavu v Ostravě 2002, 51-54.

- 2004: Frýdek-Místek (okr. Frýdek-Místek). Supermarket Kaufland, PV 45, 156-157, 197.

- 2005: Životní jubileum Vlasty Šikulové, Pravěk NŘ 13, 489-491.

- 2006: Záchranný archeologický výzkum ve Frýdku-Místku, Badania archeologiczne na Górnym Śląsku i ziemiach pogranicznych w latach 2003-2004, 233-235.

- 2009: Opava (k. ú. Kateřinky/Malé Hoštice, okr. Opava) „Na hoštických lukách“. Doba hradištní. Sídliště, pohřebiště. Záchranný výzkum, PV 50, 423.

- 2009a: Životní jubileum Vlasty Šikulové, Pravěk NŘ 18, 451-453.

- 2010: Raně středověké pohřebiště u Malých Hoštic (okr. Opava), Badania archeologiczne na Górnym Śłąsku i ziemiach pogranicznych w łatach 2007-2008, 102-108.

- 2019: 50 let od úmrtí Lumíra Jisla, ČSM B 68, 297-299.

KARGER, V., 1917: Kurzer Bericht über Vorgeschichttsforschung prähistorische Funde und Grabungen in Östterr.-Schlesien, Zeitschrift für Geschichte und Kulturgeschichte Österr. Schlesiens 12, 139-140.

- b. d.: Bericht über die Aufdeckung einer altslawische Begräbnisstätte in Kreuzendorf. Rkp. ulož. v archivu archeologického pracoviště Slezského zemského muzea č. 146.

KARGER, V., 1922: Die Vorgeschichtsforschung in Schlesien und die Ausstellung vor- und frühgeschichtlicher Altertümer im Schlesischen Landesmuseum. In: Anzeiger des schlesischen Landes-Museums in Troppau. Jahrgang I, 4-34. Troppau.

- 1922a: Předhistorické bádání ve Slezsku a výstava před- a protohistorických starožitností v Zemském museu slezském, Věstník Slezského zemského muzea v Opavě 1, 7-31.

KIRSCH, O., 2008: Německé muzejnictví na Moravě. Rkp. disertační práce HÚ FF MU v Brně, ved. práce doc. PhDr. Vladimír Goněc, CSc.

KIECOŇ, M., 2001: Středověké odpadní jímky z Opavy, Masařské ulice. Rkp. bakalářské diplomové práce ÚHM FPF Slezské univerzity v Opavě, ved. práce PhDr. Vladimír Goš, CSc.

- 2001a: Hradec nad Moravicí (okr. Opava) Zámecká ulice č. 58, parc. č. 1411. Stř̌edo- a mladohradištní období, středověk, novověk. Sídlištní objekty, hroby. Záchranný výzkum, PV 42, 207-208.

- 2005: Bruntál (okr. Bruntál). Náměstí Míru, parcela č. 91. Středověk - novověk (14.-20. století). Sídliště město. Záchranný výzkum, PV 45, 279-281.

KIECOŇ, M.-KRASNOKUTSKÁ, T.-ZEZULA, M., 2008: Hladké Životice (k. ú. Hladké Životice okr. Nový Jičín). Usedlost č. p. 8, p. č. 152/1, 153/1, 1404/75, 1404/76, 1404/77, 1404/79. Vrcholný středověk, novověk. Vesnice. Záchranný předstihový výzkum, PV 49, 397-398.

KIECOŇ, M.-PRIX, D., 2019: Záchranný archeologický výzkum u kostela Povýšení sv. Kříže v Karviné 1 Fryštátě v roce 2012, Těšínsko 2, 73-88.

KIECOŇ, M.-PRIX, D.-ZEZULA, M., 2006: Měšt’anské domy čp. 30 a 31 v Horním Benešově. Výsledky stavebněhistorického průzkumu a archeologického výzkumu - Die Bürgerhäuser Nr. 30 und 31 in Horní Benešov/Bennisch. Die historische Bauforschung und die archäologische Forschung, PRP 13, č. 2, 53-90.

KIECOŇ, M.-ZEZULA, M., 2004: Počátky a rozvoj města Opavy ve 13. a 14. století ve světle poznatků z archeologických výzkumů v 1. 2000-2002. In: Początki i rozwój miast Górnego Śłąska. Studia interdyscyplinarne 10, 57-78. Gliwice. 
- 2005: Dřevohliněná zástavba v Opavě ve středověku (současný stav výzkumu) - Die hölzerne Bebauung in Opava (Troppau) im Mittelalter (der gleichzeitige Forschungsstand), Forum urbes medii aevi II, 26-43.

- 2005a: Záchranný archeologický výzkum v místě bývalé Hradecké brány na Ostrožné ulici v Opavě (Příspěvek k poznání vývoje opavské městské fortifikace), Sborník Národního památkového ústavu v Ostravě, 99-107.

- 2007: Opava (k. ú. Opava-město, okr. Opava). Drůbeží trh, parcela č. 606, PV 48, 494-496.

- 2014: Staré Město (k. ú. Staré Město, okr. Bruntál). Kostel Neposkvrněného početí Panny Marie, parcela č. 108. Středověk, novověk. Kostel. Záchranný výzkum, PV 54, č. 2, 268-270.

KNÁPEK, A., 2008: Tesáky ze Starého Jičína, Vlastivědný sborník Novojičínska 58, 175-178.

- 2010: Středověké nálezy ze Štramberka - Medieval Finds from Štramberk, Vlastivědný sborník Novojičínska 60, 201-203.

- 2011: Plátový kabátec ze Starého Jičína, Vlastivědný sborník Novojičínska 61, 151-153.

KOHOUTEK, J., 2004: Výzkum v presbytáři kostela Neposkvrněného početí Panny Marie ve Starém Městě u Bruntálu v roce 2002 - Erforschung im Presbyterium der Kirche der Unbefleckten Empfängnis der Jungfrau Maria in Staré Město (Altstadt) bei Bruntál (Freudental) in Jahr 2002, AH 29, 493-504.

KOLÁŘ, F., 2005: Opava (k. ú. Opava-střed, okr. Opava), náměstí Osvoboditelů, PV 46, 307.

- 2006: Opava (k. ú. Opava-město, okr. Opava), ul. Holubí 2, č. p. 333, parc. č. 428, PV 47, 268-269.

- 2006a: Záchranné výzkumy na ulici Hluboké ve Frýdku-Místku, Badania archeologiczne na Górnym Śląsku i ziemiach pogranicznych w latach 2003-2004, 236-239.

- 2007: Opava (k. ú. Opava-město, okr. Opava), náměstí Osvoboditelů - Janáčkovy sady, parcely č. 9/1, 9/2, 13/1, 13/3, 13/4. 571/1. 572. Středovek-novověk (13.-20. století). Město. Záchranný výzkum, PV 48, 497-49.

- 2009: Bruntál (k. ú. Bruntál - Niské předměstí, okr. Bruntál). Ruská ulice, p. č. 1611. Novověk. Hrobka, hřbitov. Záchranný výzkum, PV 50, 376-378.

- 2010: Záchranný archeologický výzkum při kostele Nanebevzetí Panny Marie v Budišově nad Budišovkou, okres Opava - Archeologiczne badania ratownicze przy kościele Wniebowzięcia Najświętszej Marii Panny w Budišovie nad Budišovką, powiat opawski - Archäologische Notgrabungen an der Kirche Mariä himmelfahrt in Budišov an der Budišovka, Bezirk Opava, Badania archeologiczne na Górnym Śląsku i ziemiach pogranicznych w latach 2007-2008, 230-238.

- 2010a: Záchranný archeologický výzkum v Opavě, Krnovská ulice č. 17 - Ratownicze badania archeologiczne na ulicy Krnovskiej 17 w Opawie - Archäologische Notgrabungen in Opava, Krnovská-Straße Nr. 17, Badania archeologiczne na Górnym Śląsku i ziemiach pogranicznych w latach 2007-2008, 218-225.

KOLÁř, F., ed., 2013: Opavské hradby. Opava.

KOLÁŘ, F.-CEJPOVÁ, M-KANIOVÁ, P.-PRIX, D.-ROSOVÁ, R., 2018: Hradní kuchyně na dvorech opavských a ratibořských Přemyslovců. In: S knížaty u stolu. Kuchyně a kultura stolování na vévodských dvorech v Opavě a Ratiboři (Korbelářová, I.-Zezula, M., edd.), 159-187. Opava - Ratiboř.

KOLÁŘ, F.-KANIOVÁ, P.-ROSOVÁ, R.-ZEZULA, M., 2008: Opevnění města Opavy (současný stav výzkumu) - Befestigung der Stadt Troppau (Opava), Forum urbes medii aevi 5, 174-249.

KOLÁř, F.-PRIX, D.-ZEZULA, M., edd., 2016: Krnov: historie, archeologie. Ostrava.

KOLÁŘ, F.-SKALICKÁ, P., 2012: Záchranný archeologický výzkum na zámku v Branticích, okres Bruntál - Ratownicze badania archeologiczne na zamku w Branticach, powiat bruntalski - Archäologische Notgrabungen auf dem Schloss in Brantice, Bezirk Bruntál, Badania archeologiczne na Górnym Śłąsku i ziemiach pogranicznych w 2009-2010 roku, 143-151.

KOLÁŘ, F.-SKALICKÁ, P.-ZEZULA, M., 2013: Opava (k. ú. Opava-město, okr. Opava). Pekařská ulice 12. Dům umění, bývalý dominikánský klášter a kostel sv. Václava, p. č. 345, 346, 348. Středověk, novověk. Klášter. Záchranný výzkum, PV 54, č. 2, 248-249.

KOLÁŘ, F.-STŘÍLKOVÁ, J., 2005: Ostrava (k. ú. Moravská Ostrava, okr. Ostrava), Masarykovo náměstí 1, ulice Muzejní, PV 46, 311-312.

KOLÁř, F.-ZEZULA, M., 2011: Die Straßen und Ringe im mittelalterlichen und frühneuzetigen Opava Troppau aus der achäologischen Sicht, Wratislavia Antiqua 13, 219-247. 
-2014: Das Stadtgrundstück im Opava des 13. und 14. Jahrhunderts aus archäologischer Sicht. In: Tradition Umgestaltung - Innovation. In: Transformationsprozesse im hohen Mittelalter. Praehistorica - Supplementum 1 (Ggringmuth-Dallmer, E.-Klápště, J., edd.), 545-565. Praha.

- 2014a: Infrastruktura veřejných prostranství a komunikací Opavy a dalších měst moravskoslezského pomezí ve středověku a raném novověku v kontextu střední Evropy - The Infrastructure of the Public Open Spaces and Streets of Opava and Other Towns of the Moravian-Silesian Border in the Middle Ages and Early Modern Period in the Context of Central Europe. In: Středověká Evropa v pohybu (Boháčová, I.Sommer, P., edd.), 213-287. Praha.

KÖNIG, B., 1904-1905: Burgruine Karpenstein bei Landeck, Oberschlesien 3, 317-325.

- 1910: Ruine Reichenstein bei Jauernig, Zeitschrift für Geschichte und Kulturgeschichte Österreichische Schlesiens 5, 47-49.

KORBELÁŘOVÁ, I.-ZEZULA, M., edd., 2018: S knížaty u stolu. Kuchyně a kultura stolování na vévodských dvorech v Opavě a Ratiboři. Opava - Ratiboř.

KOSTRHUN, P., 2013: Prehistorie v období československé republiky. Rozvoj moravské paleolitické archeologie mezi léty 1918-1938 - Prehistory in the Czechoslovak Republic. Development of the Moravian Paleolithic archeology between the years 1918-1938. Rkp. disertační práce na ÚAM FF MU v Brně, ved. práce prof. PhDr. Vladimír Podborský, DrSc.

- 2014: Cesty moravské paleolitické archeologie v období Československé republiky. Brno.

KOUŘIL, P., 1981: První setkání členů a dopisujících spolupracovníkủ ČSSA při ČSAV v Severomoravském kraji, VVM XXXIII, 99.

- 1981a: Výzkum na Hradisku Chotěbuz-Podobora u Českého Těšína v roce 1979 - Grabung des Burgwall Chotěbuz-Podobora bei Český Těšín im Jahre 1979 (Bez. Karviná), PV 24, 45-46.

- 1982: Sondagegrabung auf dem mittelalterlichen Hausberg in Závada (Bez. Opava), PV 1980, 47.

- 1983: Mittelalterliche Funde aus Karviná (Bez. Karviná), PV 26, 59.

- 1983a: Středověká vodní tvrz v Dolních Životicích - Mittelalterliche Wasserfeste in Dolní Životice (Bez. Opava), PV 26, 57.

- 1983b: Středověké nálezy z Frýdeckého zámku (okr. Frýdek-Místek) - Mittelalterliche Funde aus dem Schloss in Frýdek (Bez. Frýdek-Místek), PV 26, 59.

- 1984: Průzkum středověkých hrádků na Frýdecko-Místecku a Jablunkovsku - Untersuchung mittelalterlicher Hausberge im Raume von Frýdek-Místek und Jablunkov (Bez. Frýdek-Místek), PV 27, 53.

- 1985: Středověká fortifikace v Čeladné nad Čeladnou v poloze zvané Kozinec (okr. Frýdek-Místek) Mittelalterliche Fortifikation ober Čeladná in der Flur genannt Kozinec (Bez. Frýdek-Místek), PV 28, 66.

- 1986: Středověký meč z Heřmanovic, okr. Bruntál - Mittelalterliches Schwert aus Heřmanovice, Kr. Bruntál, AH 11, 515-516.

- 1989: Archeologický výzkum drobného středověkého opevnění ve Stonavě (okr. Karviná) - Archeologische einer kleinen mettelalterlich Befestigung in Stonava (Bez. Karviná), PV 31, 81-82.

- 1989a: Polozemnice z 13. století z Opavy-Kateřinek - Grubenhaus aus dem 13. Jahrhundert in Opava-Kateřinky, AH 13, 107-116.

- 1989b: Př́íspěvek k poznání osídlení venkovského charakteru na Opavsku v mladší a pozdní době hradištní - Beitrag zur Erkentniss der Besiedlung ländlichen Charakters in der Gegend von Opava in der Jung- und Spätburgwallzeit, С̆MMZ 74, 203-215.

- 1989c: Revisionsuntersuchung mittelalterlicher Fortifikationen im Raum von Bruntál und Nový Jičín (Bez. Bruntál, Nový Jičín), PV 31, 81.

- 1990: Záchranný archeologický výzkum v Př́iboře (okr. Nový Jičín) - Archäologische Rettungsgrabung in Př́ibor (Bez. Nový Jičín), PV 82, 84.

- 1990a: Zjištovací archeologický výzkum na Okrouhlici (k. ú. Staříč, okr. Frýdek-Místek) - Archäologische Feststellungsgrabung auf Okrouhlice, Kat. Gebiet Staříč (Bez. Frýdek-Místek), PV 32, 46.

- 1991: Archäologische Rettungsgrabung in Opava - Gottwaldova Gasse, PV 33, 54.

- 1991a: Slovanské osídlení opavského a těšínského Slezska (stručný přehled stavu výzkumu), Śłaskie prace prahistoryczne 2, 97-105. 
- 1992: Hrad Šostýn a jeho archeologický výzkum - Burg Šostýn und ihre archäologische Forschung, ČSM B 41, 196-198.

- 1992a: Kleine mittelalterliche Befestigungen in Nordmähren und in Schlesien, Burgen und Schlösser 33, 69-71.

- 1992b: Pravěké a středověké osídlení Těšínska. In: Nástin dějin Těšínska (Valenta, J.-Borák, M., edd.), 10-16. Ostrava - Praha.

- 1992c: Sídelní komplex Štandl-Lipina u Frýdku-Místku - Siedlungskomplex Štandl-Lipina bei Frýdek-Místek, AH 17, 233-243.

- 1993: Hradec nad Moravicí a jeho archeologický výzkum - Grätz und seine archäologische Forschung. In: Český stát na přelomu 12. a 13. století, 90-93. Opava.

- 1993a: Středověká kolonizace na severovýchodní Moravě a ve Slezsku a její odraz v archeologických pramenech - Mittelalterliche Kolonisierung in Nordost-Mähren und Schlesien und ihr Abbild in archäologischen Quellen, AH 18, 141-150.

- 1994: Slovanské osídlení českého Slezska. Brno - Český Těšín.

- 1996: Slovanské hradisko a středověký hrad. In: Landek - svědek dávné minulosti (Vokřínek, P., ed.), 46-55. Ostrava.

- 1996a: Těšínsko a Velká Morava, Těšínsko 39, č. 2, 1-4.

- 1997: Severní předpolí Moravské brány a zásah velkomoravský - The north Moravian Gate and the intervention of the Great Moravian. In: Śląsk i Czechy a kultura wielkomorawska (Wachowski, K., ed.), 65-75. Wrocław.

- 1998: Frühmittelalterliche Befestigungen in Schlesien und Nordmahren. In: Frühmittelalterlicher Burgenbau in Mittel- und Osteuropa. Tagung, Nitra vom 7. bis 10. Oktober 1996 (Henning, J.-Ruttkay, A. T., edd.), 349-358. Bonn.

- 1998a: Schlesien in der Geschichte des böhmischen Staates des 9. bis 12. Jahrhunderts (Archäologische Abhandlung - zusammenfassende Übersicht). In: Slezsko v dějinách českého státu. Sborník příspěvků z vědecké konference, pořádané pod záštitou prezidenta České republiky Vaclava Havla u přiležitosti 50. výročí Slezského ústavu SZM v Opavě (Borák, M., ed.), 57-67. Opava.

- 1998b: Zu den Anfängen der slawischen Graphittonkeramik in Schlesien. In: Frühmittelalterliche Graphittonkeramik in Mitteleuropa. Naturwissenschaftliche Keramikuntersuchungen. Internationale Tagungen in Mikulčice IV (Poláček, L., ed.), 37-65. Brno.

- 2000: Opava od pravěku po období vrcholného středověku ve světle archeologických pramenů I, II, Vlastivědné listy Slezska a Severní Moravy 26, č. 1, 1-4; č. 2, 1-3.

- 2001: Záchranný archeologický výzkum na Landeku (Ostrava-Koblov), Badania archeologiczne na Górnym Śląsku i ziemiach pogranicznych w 1998 roku, 158-163.

- 2001a: Zur chronologischen Stellung von Sporen, deren Arme mit rechteckigem Rahmen beendet sind. In: Velká Morava mezi východem a západem. Spisy AÚ AV ČR Brno 17 (Galuška, L.-Kouřil, P.-Měřínský, Z., edd.), 241-255. Brno.

- 2002: Menasova ampule z hradu Rychleby (?) ve Slezsku. In: Pro arte. Sborník k poctě Ivo Hlobila (Prix, D., ed.), 15-19. Praha.

- 2002a: Středověké železné sekery ze slezských hradů a nové nálezy z hradu Quingburgu (kat. úz. Heřmanovice), Sborník bruntálského muzea, 17-30.

- 2003: Bronzová hlavice palcátu z Přerovce - Der Bronzekopf eines Morgensterns aus dem befestigten Sitz Přerovec, AH 28, 649-651.

- 2004: Raně středověký bojovnický hrob z Hradce nad Moravicí - Frühmittelalterliches Kriegergrab aus Hradec nad Moravicí, S1Arch LII, 55-76.

- 2005: Frühmittelalterliche Kriegergräber mit Flügellanzen und Sporen des Typs Biskupija-Crkvina auf mährischen Nekropolen. In: Die frühmittelalterliche Elite den Völkern des östlichen Mitteleuropas mit einem speziellen Blick auf die großmährische Problematik, Materialien der internationalen Fachkonferenz (Kouřil, P., ed.), 67-100. Brno.

- 2005a: Nové poznatky o slovanském osídlení českého Slezska. In: XIV Śląskie Spotkania Archeologiczne, 50-52. Wrocław. 
- 2006: Život v raně středověkém městě ve světle archeologie. In: Opava (Miller, J.-Žáček, R., edd.), 27-42. Opava.

- 2007: Jezdecká elita na hradisku v Chotěbuzi-Podoboře - Equestion elite riders from Chotěbuz-Podobora hillfort, Těšínsko 50, 5-8.

- 2008: Archeopark v Chotěbuzi-Podoboře u Českého Těšína - Archeopark in Chotěbuz-Podobora near Český Těšín, Těšínský muzejní sborník 3, 295-300.

- 2008a: Drobné středověké opevnění v Hrádku ve Slezsku - Kleine mittelalterliche Befestigung in Hrádek (Schlesien), Acta historica Universitatis Silesianae Opaviensis 1, 313-319.

- 2009: Das großmährische Körpergräberfeld in Opava - Malé Hoštice. In: XVI Śląskie Spotkania Archeologiczne, 9-10. Wrocław.

- 2009a: Hrad Javorník: březen 1428 - září 1434 (příspěvek k poznání hmotné kultury doby husitské ve Slezsku) - The Castle of Javorník: March 1434 - September 1438. Contribution to the History of Material Culture in the Hussite Period in Silesia, ČSZM B 58, 221-235.

- 2017: Metallfunde aus dem Burgwall Víno bei Slezské Rudoltice (Schlesien) und ihre Bedeutung. In: Archäologische Studien zum frühen Mittelalter. Archaeologica Slovaca Monographiae Communicationes 19, 53-80. Nitra.

KOUŘIL, P.-GRYC, J., 2011: Der Burgwall in Chotěbuz-Podobora und seine Stellung in der Siedlungsstruktur des oberen Odergebietes vom 8. bis zum 9./10. Jahrhundert. In: Frühmittelalterliche Zentralorte in Mitteleuropa (Macháček, J.-Ungerman, Š., edd.), 217-243. Bonn.

- 2014: Hradiska 10.-12. století na severní Moravě a v českém Slezsku - Strongholds from the 10th-12th centuries in northern Moravia and Czech Silesia. In: Funkcje grodów w państwach wczesnośredniowiecznej Europy środkowej. Społeczeństwo, gospodarka, ideologia (Chrzan, K.-Czapla, K.-Moździoch, S., edd.), 99-171. Wrocław - Glogów.

- 2014a: Chotěbuz-Podobora. In: Velká Morava a počátky křestanství - Great Moravia and The Beginnings of Christianity (Kouřil, P., ed.), 228-231, 490. Brno.

- 2018: Early Medieval Stronghold in Opava-Kylešovice and Its Importance for the Understanding of the Silesian Region in the Tenth-Eleventh Centuries. In: Moravian and Silesian Strongholds of the Tenth and Eleventh Centuries in the Context of Central Europe (Kouřil, P.-Procházka, R. et al., edd.), 185-213. Brno. - 2019: Czech Silesia in the Early Middle Ages - České Slezsko v raném středověku, PV 60, č. 2, 93-43.

KOUŘIL, P.-KOVÁČIK, P.-PRIX, D.-WIHODA, M., 2007: Tvrz a město Jeseník ve středověku - Die Festung und Stadt Jeseník (Freiwaldau) im Mittelalter, AH 32, 239-268.

KOUŘIL, P.-MĚŘÍNSKÝ, Z., 1996: Sakrální architektura a hmotné památky odrážející projevy duchovní kultury z moravských a slezských archeologických výzkumů - Sakralarchitektur und Denkmäler der Sachkultur - Widerspiegelung der Äusserungen der geistigen Kultur aus den mährischen und schlesischen archäologischen Ausgrabungen (Arbeitsthese), AH 21, 111-119.

KOUŘIL. P.-MĚ̌̌ÍNSKÝ, Z.-PLAČEK, M., 1994: Opevněná sídla na Moravě a ve Slezsku (vznik, vývoj, význam, funkce, současný stav a perspektivy dalšího výzkumu) - Befestigte Sitze in Mähren und Schlesien (Entstehung, Entwicklung, Bedeutung, Funktion, zeitgenössischer Stand und Perspektive der weiteren Untersuchungen), AH 11, 121-151.

- 2006: Haupttürme mährischer und schlesischer Burgen. In: Castrum Bene 8 - Burg und Funktion (Krenn, M.-Krenn-Leeb, A., edd.), 27-41. Wien.

KOUŘIL, P.-PAVELČÍK, J., 1985: Třicet let opavské expozitury AÚ ČSAV Brno, VVM XXXVII, 334-335. KOUŘIL, P.-PAVELČÍK, J.-TERYNGEROVÁ, H., 1987: Rettungsaktion in Opava - Kolářská Gasse, PV 30, 70-72.

KOUŘIL, P.-PLAČEK, M., 1985: Hrad Luginsland a jeho úloha v kolonizaci Krnovska - Die Burg Luginsland und ihre Aufgabe bei der Kolonisation des Krnov Gebiets, ČSM B 34, 115-127.

- 1986: Hrad Zátor u Louček (okr. Bruntál) - Burg Zátor (Bez. Bruntál), VVM XXXVIII, 303-306.

- 1986a: Revizní průzkum hradů Quingburgu a Koberštejna - Zum Schutz der slowakischen Burgen im Licht archäologischer Untersuchungen, AH 10, 221-230.

- 1987: Zbytky hradu v Moravském Berouně, okres Bruntál - Überreste der Burg in Moravský Beroun, Bez. Bruntál, ČSM B 36, 41-45. 
- 1988: Edelštejn a Leuchtenštejn - Dva hrady u Zlatých Hor, okres Bruntál - Burgen Edelštejn a Leuchtenštejn bei Zlaté Hory-Zuckmantel (Kreis Bruntál), ČSM B 37, 29-35.

- 1988a: Hrad Vartnov a jeho postavení ve vývoji hradů na Opavsku - Burg Vartnov und ihre Stellung in der Entwicklung der Burgen des Landstrichts Opava (Troppau). In: Rodná země. Sborník k 100. výročí Muzejní a vlastivědné společnosti v Brně a k 60. narozeninám PhDr. Vladimíra Někudy (Frolec, V., ed.), 285-304. Brno.

- 1988b: Vznik, vývoj a funkce čtyř hradů v okolí Vrbna pod Pradědem (okres Bruntál) - Die Entstehung, Entwicklung und Funktion der vier Burgen in der Umgebung von Würbenthal (Vrbno pod Pradědem, Kreis Bruntál), ČSM B 37, 241-251.

KOUŘIL, P.-PRIX, D., 1991: Kostel sv. Jiří v Pelhřimovech, okr. Bruntál, ČSZM B 40, 1-8.

- 1995: Drobné středověké opevnění v Bílé - Eine kleine mittelalterliche Befestigung in Bílá, Acta historica et museologica Universitatis Silesianae Opaviensis C 2, 46-58.

- 2008: Drobná středověká opevnění ve Skorošicích u Javorníku - Kleine mittelalterliche Befestigung in Skorošice bei Javorník (Gurschdorf bei Jauernig), AH 33, 169-183.

- 2011: Drobné středověké opevnění v Hradci, okr. Jeseník - Eine kleine mittelalterliche Befestigung in Hradec, Bezirk Jeseník, AH 36, 165-176

KOUŘIL, P.-PRIX, D.-WIHODA, M., 1997: Městské hrady v českém Slezsku - Stadtburgen in Böhmisch-Schlesien, AH 22, 249-272.

- 1998: Středověké fortifikace a „Jesenická stezka“ v údolí Černé Opavy - Mittelalterliche Befestigungen und die „Gesenker Strasse“ im Tal der Schwarzen Oppa, AH 23, 111-131.

- 2000: Hrady českého Slezska. Brno - Opava.

- 2002: Česká kastelologie na rozcestí? - Czech casteology at the crossroads?, AH 27, 21-35.

- 2005: Středověké opevnění v Adolfovicích na Jesenicku - Die mittelalterliche Befestigung in Adelsdorf, Kreis Freiwaldau, AH 30, 199-226

- 2006: Středověké opevnění v Ondřejovicích, okres Jeseník - Mittelalterliche Festeplatze in Ondřejovice, Bezirk Jeseník, AH 31, 215-234.

- 2019: Drobné středověké opevnění v Bohušově na Osoblažsku a dosud neznámé metalické nálezy z hrádku ve Skorošicích na Javornicku - Small medieval fortifications in Bohušov in Osoblaha region and hitherto unknown metallic finds from the small castle in Skorošice in the Javorník region. In: Na hradech a tvrzích. Miroslavu Plačkovi k 75. narozeninám (Dejmal, M.-Jan, L.-Procházka, R., edd.), 239-257. Praha.

KOUŘIL, P.-PROCHÁZKA, R., 2018: Moravian Centres between the Mojmirids and Přemyslids. In: Moravian and Silesian Strongholds of the Tenth and Eleventh Centuries in the Context of Central Europe (Kouřil, P.-Procházka, R., edd.), 41-72. Brno.

KOUŘIL, P.-TERYNGEROVÁ, H., 1987: Záchranný archeologický výzkum v Opavě - Archäologsche Rettungsgragung in Opava (Bez. Opava), PV 29, 44.

- 1994: Archeologické oddělení PÚ v Ostravě - jeho vznik a cíle, Sborník PÚ v Ostravě, 51-52.

- 2002: Středověký poutní odznak z historického jádra města Opavy. In: Civitas \& villa. Miasto i wieś w średniowiecznej Europie środkowej (Buśko, C.-Klápště, J.-Leciejewicz, L.-Możdzioch, S., edd.), 227-234. Wrocław - Praha.

KOUŘIL, P.-TYMONOVÁ, M., 2013: Slovanský kostrový mohylník ve Stěbořicích. S př́íspěvky Petra Velemínského, Jakuba Likovského a Martina Hájka. Spisy Archeologického ústavu AV ČR 34. Brno.

KOUŘIL, P.-WIHODA, M., 1996: Die Burgen böhmisch Schlesiens. Ihre Entstehung, Funktion und Stellung in der Siedlungsstruktur. In: Kultura średniowiecznego Śląska i Czech (Wachowski, K., ed.), 67-84. Wrocław.

- 2001: Wüstehubové. Ď́alovo plémě nebo tvůrcové kulturní krajiny? - Die Adelsfamilie Wüstehube. Teufelsgeschlecht oder die Schöpfer einer Kulturlandschaft?, ČSZM B 50, 205-217.

- 2003: Etnické trojmezí? Výpověd' písemných a hmotných pramenů k etnické struktuře moravsko-slezského pomezí v epoše vrcholného středověku - Ethnische Dreischeide? Aussage schriftlicher und materieller Quellen zur ethnischen Struktur des mährisch-schlesischen Grenzgebiets im Hochmittelalter, AH 28, 69-111.

- 2004: „... Iohannes Witshub fecit castrum nomine Vridebergk...“ Die Burg und ihr Hinterland am Beispiel der schlesischen Materie „... - Iohannes Wisthub fecit castrum nomine Vridebergk...“ Le château et 
son environnement à l'exemple de la matière silésienne. In: Burgen und Siedlungsstruktur (Ruttkay, A.Ruttkay, M.-Bednár, P., edd.), 105-134. Nitra.

KOUŘIL, P.-ŽÁČEK, P., 1986: Drobná středověká opevnění v Pobeskydí a otázka jejich klasifikace - Kleine mittelalterliche Befestigungen und die Frage deren Klasifizierung, ČSZM B 35, 97-138.

- 1987: Drobné středověké opevnění Lipina a jeho archeologický výzkum - Kleine mittelalterliche Befestigung Lipina und ihre archäologische Untersuchung, AH 12, 375-382.

KOVÁČIK, P.-DUDKOVÁ, V.-LAFKOVÁ, H., 2016: Poznatky ke stavebnímu vývoji a k pohřbívání v kostele sv. Kříže u Javorníku-Vsi na základě archeologického výzkumu - New knowledge about construction, historical development and burials in St. Cross church in Javorník based on archaeological research, PV 57, č. 2, 177-196.

KOVÁČIK, P.-MALÍK, P.-ZEZULA, M., 2008: Opava (k. ú. Opava-město, okr. Opava). Nákladní ulice p. č. 94/1; 97; 98/2;104/3, 4, 9, 15; 117/1;602; 603. Vrcholný a pozdní středověk, novověk. Město. Zjištovací výzkum, PV 49, 426-429.

KOVÁČIK, P.-SCHÖN, M., 2011: Zlaté Hory (okr. Jeseník), Náměstí Svobody, Polská ulice. Novověk. Město. Záchranný výzkum, PV 52, č. 2, 211.

KOVÁČIK, P.-SCHÖN, M.-ZEZULA, M., 2008: Bohumín (k. ú. Starý Bohumín, okr. Karviná). Nám. Svobody, č. p. 26, 27. Středověk-novověk. Město. Záchranný výzkum, PV 49, 351-352.

KOVÁČIK, P.-VESELÁ, B., 2009: Stove tiles from Starý Bohumín - Kachle ze Starého Bohumína - Die Kachlen von Starý Bohumín, Studies in Post-Medieval Archeology 3, 289-301.

- 2006: Jeseník (okr. Jeseník). Masarykovo náměstí. Parc. č. 435, 437/1, 437/3. Stř̌edověk, novověk. Sídliště město. Záchranný výzkum. Uložení Muzeum Jeseník, PV 47, 233-234.

KOVÁČIK, P.-TOBIASZOVÁ, A., 2011: Velká Polom (okr. Ostrava). Intravilán obce, č. p. 600, 601/1. Středověk, novověk. Tvrz. Záchranný výzkum, PV 52, č. 2, 205.

KOZÁK, P.-PRIX, D.-ZEZULA, M., edd., 2011: Kostel sv. Martina v Bohušově. Bohušov - Ostrava.

KRÁL, J., 1956: Nález středověké keramiky v Opavě, ČSM B 5, 11-25.

- 1958: Eine vorläufige Mitteilung über di slavische Besiedlung in der Gemeinde Úvalno, Bez. Krnov, PV 3, 82-84.

- 1958a: Zpráva o drobných zachraňovacích akcích expositury v Opavě, PV 1958, 104.

- 1959: Slovanská osada z 9. století v Úvalně, okr. Krnov, ČSM B 8, 82-100.

- 1960: Přehled výzkumů opavské expositury archeologického ústavu ČSAV pob. v Brně za rok 1959, PV 4, 177-179.

- 1961: Opavské středověké nálezy - Mittelalterliche Funde aus Opava, ČSM B 10, 19-35.

- 1961a: Opavské středověké nálezy - II. Popská ulice a Vaškovo náměstí - Mittelalterliche Funde (II) aus Opava, ČSM B 10, 19-36.

- 1961b: Z výzkumů opavské expositury Archeologického ústavu ČSAV, pob. v Brně - Von den Ausgrabungen des AÚ ČSAV, Zweigstelle Brno, Expositur in Opava, im Jahre 1960, PV 5, 106-109.

- 1963: Mittelalterliche Funde aus Ostrava im Jahre 1962, PV 7, 66-68.

- 1964: Středověké nálezy v Opavě 1963 - Mittealterliche Funde in Opava 1963, PV 8, 67.

- 1964a: Středověké nálezy v Ostravě - Mittelalterliche Funde in Ostrava, ČSM B 13, 1-8.

- 1966: Slovanské hradisko v Opavě-Kylešovicích - Slawischer Burgwall in Opava-Kylešovice, PV 10, $72-73$.

- 1967: Hrnčířská pec v Bruntále - Ein Töpferofen in Bruntál, PV 11, 54-55.

- 1968: Nález stř̌edověkých vrat v Opavě v roce 1968 - Fund elnes mittelalterlichen Tores in Opava im Jahre 1967, PV 12, 111-112.

- 1971: Slovanské sídliště v Hněvošicích - Die slawische Siedlung von Hněvošice (Bez. Opava), PV 14, 24.

- 1971a: Tři drobné nálezy z minulosti Krnova, Slezsko 3, 33.

- 1973: Nález mince a hřebů na Vikštejně obec Radkov-Dubová (okr. Opava) - Fund einer Minze und von Nägeln auf Vikštejn, Gemeinde Radkov (Bez. Opava), PV 17, 88.

- 1973a: Zachraňovací akce v Dolním Benešově (okr. Opava) - Rettungsgrabung in Dolní Benešov (Bez. Opava), PV 17, 89-90.

- 1974: Nálezové prostředí středověké keramiky. In: Archeologický sborník, 102-112. Ostrava.

- 1974a: Středověké nálezy v Opavě 1973 - Mittelalterliche Funde in Opava 1973 (Bez. Opava), PV 18, 101-102. 
- 1975: Archeologické nálezy v Opavě v roce 1974 (okr. Opava) - Archäologische Funde in Opava im Jahre 1974, PV 19, 82.

- 1975a: Keramické zvonky ze středověkých nálezů - Tonschellen in mittelalterlichen Funde, AR XXVII, 387-389.

- 1977: Opavský nález cínového víka - Opava Fund von Blechdeckel, ČSM B 26, 188-189.

KRASNOKUTSKÁ, T., 2005: Středověké a novověké kachle z Opavy. Katalog nálezů z archeologických výzkumů. Archaeologiae Regionalis Fontes 8. Olomouc.

KRASNOKUTSKÁ, T.-TERYNGEROVÁ, H., 2008: Záchranné archeologické výzkumy realizované v prostoru zámku v Klimkovicích v letech 2006 a 2007, Sborník Národního památkového ústavu v Ostravě, 139-148.

KRASNOKUTSKÁ, T.-ZEZULA, M., 2008: Velké Heraltice (k. ú. Velké Heraltice, okr. Opava). Usedlost č. p. 199, č. p. 789. Vrcholný středověk. Vesnice. Záchranný výzkum, PV 49, 453.

KRAVAR, Z., 2008: Říšské župní muzeum Opava (1894, 1938-1945). Inventář. In: Inventáře a katalogy Zemského archivu v Opavě, NAD 231, č. pomůcky 1614. Opava.

- 2014: Faustin Ens. Das Oppaland, oder Troppauer Kreis, nach seinen geschichtlichen naturgeschichtlichen, bürgerlichen und örtlichen Eigenthümlichkeiten. In: Země a její muzeum. Slezské zemské muzeum a muzejní tradice českého Slezska (Š́l, J. a kol., edd.), 32-33. Opava.

KRUŤA, T., 1958: Dějiny dolování ve Zlatých Horách (Cukmantlu) ve Slezsku, VVM XIII, 77-84, 149-155.

KULKA, R., 1903: Bericht uber die Wanderversammlung in Troppau und Jagerndorf, Sitzungsberichte der Anthropologischen Gesellschaft in Wien, Jhrg. 1903, Mitteilungen der anthropologischen Gesellschaft in Wien 33, 89-99.

MACHÁČEK, P., 2011: Sto deset let muzejní práce v Javorníku, Vlastivědné listy Slezska a Severní Moravy 37, č. 2, 6-10.

MALÍK, P., 2014: Záchranný archeologický výzkum na zřícenině hradu Fürstenwalde - The archeological Rescue Survey at the Ruined Fürstenwalde Castle, Sborník Národního památkového ústavu v Ostravě, 134-143.

MALÍKOVÁ, H., 2016: Středověké a raně novověké hračky a součásti her v archeologické podsbírce Slezského zemského muzea - Middle Ages and Early Modern Ages Toys and Components of Games in Archaeological Sub-collection of Silesian Museum in Opava, ČSZM B 65, 1-12.

MALÍKOVÁ, H.-SKALICKÁ, P., 2016: K datování hospodářské stavby z areálu dominikánského kláštera v Opavě - On Dating of an outbuilding in the premises of Dominican Monastery in Opava, ČSZM B 65, $223-236$.

MARETHOVÁ, B., 2012: Poutní odznak. In: Předměty vyprávějí. Hmotná kultura středověké a raně novověké Opavy ve světle nálezů z archeologických výzkumů v prostoru bývalé Radniční ulice a v areálu opavského pivovaru (Vojůvková, K.-Zezula, M., edd.), 58-59. Opava.

- 2018: Nález cylindrického pouzdra s brakteáty z Opavy z prostoru bývalé Radniční ulice - A cylindrical bracteate holder found in Opava, former Radniční Street, Numismatický sborník 32, 91-96.

MĚCHUROVÁ, Z., 1994: Funde der kleinen mittelalterlichen Plastik aus dem Gebiet tschechischen Schlesiens, AR XLVI, 618-626.

- 1995: Nálezy drobné středověké plastiky na území českého Slezska. In: Ostrava. Příspěvky k dějinám a současnosti Ostravy a Ostravska (Jiřík, K., ed.) 17, 351-359. Ostrava.

- 1996: Archeologie na Ostravsku - Die Entwicklung der Archäologie im Ostrauer Gebier, AR XLVIII, 565-579.

- 1996a: Výrobky z kosti z hradu Landeka (obec Koblov, okr. Ostrava) - Knochenprodukte aus Burg Landek (Gem. Koblov, Bez. Ostrava), ČMMZ 81, 155-165.

- 2004: Kovové a luxusní nálezy z hradu Landeka u Ostravy (kat. Koblov) - Metall- und Luxusgegenstände aus der Burg Landek bei Ostrava (Gem. Koblov), ČMMZ 89, 219-252.

- 2009: Slezskoostravský hrad v archeologických nálezech, Zpravodaj Ostravského muzea 16, č. 1, 36-56.

- 2011: K archeologii na Slezskoostravském hradě - Zur Archäologie auf der Schlesisch-Ostrauer Burg. In: Hrad jako technický problém: technologie a formy výstavby středověkých opevněných sídel (Měřínský, Z., ed.), 75-88. Brno. 
- 2013: Drobné středověké a novověké nálezy z Ostravy ve sbírkách Slezského zemského muzea v Opavě Minor medieval and modern findings from Ostrava in the collections of Silesian Museum in Opava, ČSZM B 62, 185-198.

- 2014: Heslo I/24 Počátky muzejnictví v Ostravě a Karel Jaromír Bukovanský. In: Země a její muzeum. Slezské zemské muzeum a muzejní tradice českého Slezska (Šíl, J. a kol., edd.), 78. Opava.

- 2014a: Rozkládací krabice s prehistorickými artefakty K. J. Bukovanského. In: Země a její muzeum. Slezské zemské muzeum a muzejní tradice českého Slezska (Šíl, J. a kol., edd.), 81. Opava.

MĚŘíNSKÝ, Z., 1981: Přehled dosavadního stavu výzkumu fortifikací 11. až počátku 16. století na Moravě a ve Slezsku (hradiska a hrady) - Übersicht des bisherigen Standes der Erforschung von Befestigungen aus dem 11. bis Anfang des 16. Jh. in Mähren und Schlesien Burgwälle und Burgen, AH 6, 147-197.

- 1989: Století posledních Přemyslovců na Moravě a ve Slezsku ve světle archeologických výzkumů a nálezů - Das Jahrhundert der letzten Přemysliden in Mähren und Schlesien im Lichte archäologischer Forschungen und Funde, AH 14, 19-42.

- 1991: Vývoj osídlení na Moravě a ve Slezsku (současný stav výzkumu) - Die Entwicklung der Besiedlung in Mähren und Schlesien (der gegenwärtige Forschungsstand), AH 16, 27-36.

- 1993: Otázky kolonizace a interetnických vztahů na středověké Moravě - Fragen der Kolonisation und der interethnischen Beziehungen im mittelalterlichen Mähren, AH 18, 99-118.

- 2006: Befestigte Zentren der frühen Přemysliden-Periode in Mähren und Schlesien (Thesen), AH 31, 55-66.

- 2011: Za PhDr. Jaroslavem Králem: 15. listopadu 1921 - 3. června, AH 36, 629-630.

- 2014: Dějiny a stav výzkumu Velké Moravy. In: Velká Morava a počátky křest’anství (Kouřil, P., ed.), 16-22. Brno.

MĚ̌̌ÍNSKÝ, Z.-PLAČEK, M., 1991: Anfänge der Burgsteinarchitektur in Mähren und Schlesien und ihre mitteleuropäischen Wechselbeziehungen, С̆MM B 76, 85-106.

- 1991a: Vývoj hradní architektury na Moravě a ve Slezsku od husitských válek do 1. třetiny 16. století Entwicklung der Burgarchitektur In Mähren und In Schlesien seit den Hussitenkriegen bis In das 1. Drittel des 16. Jahrhunderts, AH 6, 215-232.

MĚŘÍNSKÝ, Z.-PROCHÁZKA, R., 2010: K některým aspektům každodenního a svátečního života středověkého člověka na Moravě a ve Slezsku - Zu einigen Aspekten des Alltags- und Feiertagslebens des mittelalterlichen Menschen in Mähren und Schlesien, AH 35, 7-44.

MICHNOVÁ, V.-POLANSKÝ, L.-TOMKOVÁ, L.-TYMONOVÁ, M., 2010: Komárovský poklad. Revize. Revize dochované části torza depotu - The Komárov hoard re-discovered. Description and the preserved part of the hoard revised, Numismatické listy 65, 98-126.

MIKETOVÁ, H.-MÜLLER, K., edd., 2012: Opavský zámek. Opava.

MINAŘÍK, J., 2019: Herbert Weinelt: krátká cesta bruntálského historika. Příspěvek k dějinám sudetoněmecké vědy na Moravě. Rkp. nepubl. bakalářské práce na HÚ FF MU v Brně, ved. práce Mgr. Jiří Němec, Ph.D.

MONÍK, M.-PLAŠTIAKOVÁ, M.-KOVÁČIK, P.-CHEBEN, M., 2007: Rýžoviště v údolí Zámeckého potoka ve Zlatých horách. In: Stříbrná Jihlava. Studie k dějinám hornictví a důlních prací, 76-81. Jihlava.

MORAVEC, Z., 2007: Ostrava (k. ú. Moravská Ostrava, okr. Ostrava). Kostelní ulice č. 2. Středověk, novověk (14.-17. st.). Sídliště. Záchranný výzkum, PV 48, 500-501.

- 2007a: Tvář středověké Ostravy. Ostrava.

- 2007b: Záchranný archeologický výzkum na Kostelní ulici v Moravské Ostravě - Badania archeologiczne na ulicy Kościelnej w Ostrawie - Archäologische grabungen in der Kostelní-strasse in Ostrava, Badania archeologiczne na Górnym Śląsku i ziemiach pogranicznych w latach 2005-2006, 227-230.

-2009: Archeologický výzkum na Kostelní ulici 2 v Moravské Ostravě, Zpravodaj Ostravského muzea 16, 58-76.

- 2010: Archeologický výzkum na Puchmajerově ulici v Ostravě - Badania archeologiczne na ulicy Puchmajerowej w Ostrawie - Archäologische Untersuchungen in der Puchmajer-Straße in Ostrava, Badania archeologiczne na Górnym Śląsku i ziemiach pogranicznych w 2007-2008 roku, 208-213.

- 2011: Ostrava a její blízké okolí v době kolem první poloviny 14. století. In: Král, který létal. Moravsko-slezské pomezí v kontextu středoevropského prostoru doby Jana Lucemburského (Majer, D., ed.), 107-158. Ostrava. 
- 2012: Archeologická výstava v Moravské Ostravě v roce 1888, Pravěk NŘ 20, 325-334.

- 2012a: Předstihový archeologický výzkum na Muzejní ulici v Ostravě - Archeologiczne badania poprzedzające na ulicy Muzejnej w Ostrawie - Vorausgehende archäologische Untersuchungen in der Muzejní-Straße in Ostrava, Badania archeologiczne na Górnym Śłąsku i ziemiach pogranicznych w 20092010 roku, $80-84$.

- 2013: Odpadní jímka z ulice 28. října v Ostravě - A waste-water trap in 28th October Street in Ostrava, ČSM B 62, 199-208.

- 2013a: Ulice středověké Ostravy - The streets of medieval Ostrava, Příspěvky k dějinám a současnosti Ostravy a Ostravska 27, 83-109.

- 2017: Archeologické prameny: Každodenní život středověkého měšt’ana. In: Ostrava. Počátky a vývoj středověkého města (Przybylová, B., red.), 154-181. Ostrava.

- 2019: Archeologické vykopávky K. J. Bukovanského ve slezských částech dnešní Ostravy, Vlastivědné listy Slezska a severní Moravy 45, č. 1-2, 11-12.

- 2019a: Kachlový soubor z Kostelního náměstí v Ostravě. Ostrava.

MORAVEC, Z.-ZEZULA, M., 2017: Archeologické prameny: Každodenní život středověkého měšt’ana. In: Ostrava. Počátky a vývoj středověkého města (Przybylová, B., red.), 154-181. Ostrava.

NEKUDA, V., 1969: 150 let Moravského musea v Brně. Stručný přehled historického vývoje. Brno.

NEKUDA, V.-UNGER., 1981: Hrádky a tvrze na Moravě. Brno.

NOVÁK, J.-ŠTĚPÁN, V., 1984: Vývoj dolování zlata ve zlatohorském rudném revíru do počátku 17. století, Studie z dějin hornictví 15, 70-86.

- 1985: Těžba a rýžování zlata v Jeseníkách, Vlastivědné listy Slezska a Severní Moravy 11, 30-32.

- 1986: Exploatace zlata na Bruntálsku v 16. století, ČSM B 35, 46-60.

- 1987: Horní města na severní Moravě, SM 54, 37-43.

NOVOTNÝ, B., 1959: Archeologický výzkum Hradce u Opavy - Archäologische Forschung von Hradec u Opavy, Slezský sborník 57, 447-463.

- 1962: Výzkum slovanského hradiska v Opavě-Kylešovicích - Grabung auf dem Burgwall in Opava-Kylešovice, ČSM B 11, 65-80.

- 1978: Výzkum přemyslovského ústředí „castrum Zpitignew“ z 11.-12. století a rekonstrukce jeho údělu v archeologických a písemných pramenech - Erforschung des Premyslidenzentrums „Castrum Zpitignew“ aus dem 11.-12. Jahrhundert und die Rekonstruktion seines Territoriums in archäologischen und schriftlichen Quellen, AH 3, 183-215.

NOVOTNÝ, G., 2009: Černohorský, Karel Václav. In: Biografický slovník českých zemí 11, 14-16. Praha. NÝVLTOVÁ FIŠÁKOVÁ, M., 2004: Zvířecí kosti ze středověkých jímek v Opavě - Tierknochen aus mittelalterlichen Gruben in Opava, ČSZM B 53, 1-17.

- 2007: Nález chrta na hradisku Chotěbuz-Podobora - Greyhound find from Chotěbuz-Podobora hillfort, Těšínsko 50, č. 1, 29-31.

- 2008: Nález lidských pozůstatků z hradiska v Chotěbuzi-Podoboře, Těšínsko 51, č. 2, 1-4.

- 2010: Local elite from Chotěbuz-Podobora from zooarcheological and archeological point of view - Animals as Material Culture in the Middle Ages. Bestial Mirrors, VIAS 3, 31-38.

- 2012: Paleopatologické nálezy na třech zvířecích kostrách ze středověké jímky v Opavě - Paleopathological finds on three animal skeletons from the medieval cess-pit in Opava. In: Mezi raným a vrcholným středověkem. Pavlu Kouřilovi k šedesátým narozeninám přátelé, kolegové a žáci (Doležel, J.-Wihoda, M., edd.), 365-372. Brno.

OPRAVIL, E., 1961: Botanické nálezy z archeologického výzkumu středověku města Opavy (1350-1500), Př́rodovědný časopis slezský 22, 361-366.

- 1974: Moravskoslezský pomezní les do začátku kolonizace, Archeologický sborník, 113-133.

- 1990: Archeobotanické nálezy z Kolářské ulice v Opavě - Archäobotanische Funde aus der Kolářská-Gasse in Opava, AH 15, 491-509.

- 1994: Výsledky archeobotanické analýzy z hradiska Chotěbuz-Podobora. In: Slovanské osídlení českého Slezska (Kouřil, P., ed.), 168-173. Brno - Český Těšín.

PACHL, H., 1983: Jauernig und das Jauerniger Ländchen. Regensburg. 
PALOWSKÁ, M., 2015: Vliv národopisné výstavy v Orlové roku 1894 na vznik současného Ostravského muzea - The Influence of 1894 Ethnographic Exhibition in Orlová on the Foundation of the Current Museum of Ostrava, Prameny a studie 56, 101-104.

PAVELČÍK, J., 1960: Průzkum kostela v Osoblaze - Die Durchforschung die Kapelle in Osoblaha, PV 4, 130. - 1960a: Zjištovací výzkum ve Štramberku - Feststellunggrabung in Štramberk, PV 1959, 66.

- 1971: Slovanské objekty v Hradci u Opavy - Slawische Objekte in Hradec bei Opava (Bez. Opava), PV 15, 54.

- 1972: Záchranné akce na náměstí Svobody v Opavě - Rettungsaktion am náměstí Svobody (Freiheitsplatz) in Opava (Bez. Opava), PV 16, 126-127.

- 1973: Paleolitická stanice a osada lidu s lineární keramikou v Oticích (okr. Opava) - Paläolithische Station und Niederlassung der Trager der Linearbandkeramik in Otice (Bez. Opava), PV 17, 17.

- 1973a: Pravěké nálezy z Hradce nad Moravicí - Vorgeschichtliche Funde aus Hradec nad Moravicí (Bez. Opava), PV 17, 96-97.

- 1974: Středověká osada v Albrechticích - Mittelalterliche Niederlassung in Albrechtice (Bez. Karviná), PV 18, 82.

- 1974a: Záchranná akce ve Vávrovicích-Palhanci (okr. Opava) - Bergungsaktion in Vávrovice-Palhanec (Bez. Opava), PV 19, 112-113.

- 1975: Dvacet let opavské expozitury AÚ ČSAV Brno, AR XXVII, 361-364.

- 1975a: Dvacet let práce opavské expozitury Archeologického ústavu ČSAV v Brně, Vlastivědné listy Slezska a Severní Moravy 1, 45-48.

- 1978: Hradisko u Kobeřic (okr. Opava) - Der Burgwall bei Kobeřice (Bez. Opava), PV 21, 128-129.

- 1978a: Nově zjištěné lokality ve Velkých Hošticích (okr. Opava) - Neu festgestellte Lokalitäten in Velké Hoštice (Bez. Opava), PV 23, 128.

- 1978b: Středověké nálezy z Opavy - Masařské ulice - Mittelalterliche Funde aus Opava - Masařská-strasse, PV 21, 101.

- 1980: Schlavische Funde in Hradec nad Moravicí (Bez. Opava), PV 1977, 80.

- 1980a: Další nálezy z Otic-Sopky - Weitere Funde aus Otice-Sopka (Bez. Opava), PV 22, 112.

- 1980b: Záchranná akce ve Velkých Hošticích (okr. Opava) - Rettungsaktion Velké Hoštice (Bez. Opava), PV 22, 111.

- 1981: Středověké nálezy z Albrechtic - Mittelalterliche Funde aus Albrechtice (Bez. Karviná), PV 23, 60-61.

- 1989: Pravěká a časně historická lokalita u Neplachovic (o. Holasovice, okr. Opava) - Prähistorische Lokalitetten bei Holasovice (Bez. Opava), PV 31, 96.

- 1989a: Pravěké lokality u Holasovic - Prähistorische Lokalitäten bei Holasovice (Bez. Opava), PV 31, 95-96.

- 1989b: Terénní průzkum Kostelního kopce v Opavě-Jaktaři (okr. Opava) - Geländeuntersforschung im Raum von Kostel ni kopec in Opava-Jaktař (Bez. Opava), PV 31, 96.

- 1990: Povrchový sběr v Neplachovicích (okr. Opava) - Lesefunde aus Neplachovice (Bez. Opava), PV 32, 98.

- 1993: Životní jubileum Vlasty Šikulové, Vlastivědné listy Slezska a Severní Moravy 19, 43.

- 1993a: Záchranná akce na „Kostelním kopci“v Opavě-Jaktaři (okr. Opava) - Rettungsaktion am „Kostelní kopec" (Kirchenberg) in Opava-Jaktař (Bez. Opava), PV 36, 110-111.

PETER, A., 1870: Heidnische Grabalterthümer in Schlesien, Mittheilungen der k. k. Central-Commision zur Erforschung und Erhaltung der Baudenkmale 15, 80-81.

PÍSKOVÁ, M., 1997: Napajedelská léta Vincence Praska - Vincenc Prasek’s Years in Napajedla, Acta historica at museologica Universitatis Silesianae Opaviensis 3, 154-161.

PLAČEK, M., 2006: Dvě méně známé tvrze na moravském břehu Odry - Zwei weniger bekannte Festen auf dem mährischen Ufer des Flusses Odra, AH 31, 249-258.

PODBORSKÝ, V., 1995: Jubilantka Vlasta Šikulová, Pravěk NŘ 3, 312-313.

- 1996: 25. výročí úmrtí Lumíra Jisla, Pravěk NŘ 4, 400.

POKLUDOVÁ, A., 2005: Karel Jaromír Bukovanský - pedagog, vlastivědný pracovník, archeolog, publicista a zakladatel českého muzejnictví ve Slezsku, ČSZM B 54, 26-52. 
POLOCZKOVÁ, B., 1977: Inž. Wiktor Karger, ČSM B 26, 1, 7-31.

POSPÍŠIL, J., 1899: Krátký přehled předhistorických památek slezských, Věstník Matice opavské 8, 1-11.

POULÍK, J., Nové slovanské výzkumy na Moravě, Vznik a počátky Slovanů I, 239-258.

PRASEK, V., 1875: Všehochut' z cesty po Slezsku, Opavský týdeník 6, č. 35, 286.

- 1875a: Všehochut' z cesty po Slezsku, Opavský Týdeník 6, č. 41, 334-336.

- 1885: Z dávnověkosti Těšína I., Opavský týdeník 16, č. $96,1$.

- 1886: Burg Wiegstein, Opavský týdeník 101, č. 228, 1-2.

- 1886a: Kylešovská tvrz, Opavský týdeník 17, č. 68, 3.

- 1889: Historická topografie země Opavské. Opava.

- 1891: Dějiny kraje Holasovského čili Opavského. Opava.

- 1894: Dějiny knížectví Těšínského. Opava.

PRIX, D., 2017: Kostel sv. Václava. In: Počátky a vývoj středověkého města (Antonín, R. et. al.), 28-45. Ostrava.

- v tisku: Exkurz 3. Holasovice, zděný raně gotický kostel neznámého zasvěcení. In: Holasovice - Loděnice - Štemplovec - Kamenec. Dějiny obcí (Rosová, R. a kol., edd.). Holasovice.

PRIX, D.-ZEZULA, M., 2000: Archeologický výzkum kostela Nanebevzetí Panny Marie v Branticích, okr. Bruntál - Archäologische Erforschung der Kirche Mariä Himmelfahrt in Brantice (Bransdorf), Bez. Bruntál, AH 25, 279-305.

- 2002: Archeologický výzkum a stavebně historický průzkum minoritského kláštera v Opavě v roce 2000 - Die archäologischen Untersuchungen und die bauhistorische Erforschung des Minoritenklosters in Troppau im Jahre 2000. In: Ve stopách sv. Benedikta (Jan, L.-Obšusta, P., edd.), Disputaciones Moravicae 3, 275-294.

- 2002b: Záchranný archeologický výzkum a stavebně historický průzkum minoritského kláštera v Opavě, Badania archeologiczne na Górnym Śłasku i ziemiach pogranicznych w łatach 1999-2000, 303-315.

- 2003: Středověké osídlení Bohušova a počátky kostela sv. Martina - Die mittelalterliche Besiedlung des Dorfes Bohušov (Bez. Bruntál) und Anfänge der St. Martin-Kirche, AH 28, 433-460.

PROCHÁZKA, R., 2007: Archeologie a poznání moravských a slezských měst - Die Archäologie als Mittel zum Kennenlernen von mährischen und schlesischen Städten im Mittelalter (Ein Beitrag zur Frage der Anordnung des Raumes), AH 32, 37-80.

- 2009: Vývoj opevňovací techniky na Moravě a v českém Slezsku v raném středověku. Spisy AÚ AV ČR v Brně 38. Brno.

PROCHÁZKA, R.-HLOŽEK, M., 2013: Opavský džbán v Brně? K otázce počátků vrcholně středověké glazované keramiky - Opavian jug in Brno? To the question of the beginnings of the Late Middle Ages glazed pott, ČSZM B 62, 231-244.

RASCHKE, G., 1941: Grabungen an der frühromanischen Burgkapelle von Teschen, Altschlesien 10, $146-161$.

RATAJ, J., 1970: Seznam prací PhDr. Lumíra Jisla, CSc., AR XXII, 207-221.

RATAJ, J.-ŠOLLE, M.-VENCL, S., 2003: Vzpomínky pracovníků Státního archeologického ústavu v Praze, AR LV, 139-165.

ROSOVÁ, R. a kol., v tisku: Holasovice - Loděnice - Štemplovec - Kamenec. Dějiny obcí. Holasovice.

RYCHLÝ, M., 2018: Hmotná kultura středověkých opevněných sídel na Javornicku (okr. Jeseník) - Material culture of Medieval fortified settlements in Javorník region, district of Jeseník. Rkp. magisterské práce na ÚA FPF Slezské univerzity, ved. práce PhDr. et PhDr. Markéta Tymonová, Ph.D., Opava.

SARTORI, F., 1818: Urnen in Fürstenthum Jägerndorf gefunden. In: Mahlerisches Taschenbuch für Freunde interessanter Gegenden, Natur- und Kunst Merkwürdigkeiten der Österreichischen Monarchie 6, 180-182. Wien.

SEDLÁČKOVÁ, H., 2004: Archeologické nálezy skla z hradu Cvilín u Krnova, okr. Bruntál, VVM LVI, 367-379.

- 2004a: Středověké sklo z Opavy - Das mittelalterliche Glas aus Opava (Troppau), PA 95, 223-264.

SCHENK, Z., 2004: Nejstarší neolitické osídlení jihozápadní části Moravské brány (k problematice osídlení přerovského regionu v období kultury s lineární keramikou), Sborník SOA v Přerově, 6-41. 
SCHIRMEISEN, K., 1937: Auf den Spuren eines mittelalterlichen Dorfes bei Benisch, Benischen Ländchen $3,81-85$.

SCHRÁNIL, J., 1925: Několik příspěvků k poznání kulturních proudů v zemích českých v X. a XI. věku, Obzor prehistorický 4, 175-177.

SCHUCHHARDT, C., 1931: Die Burg im Wandel der Wellgeschichte. Potsdam.

SKALICKÁ, P., 2014: Heslo III/4.3. Gustav Stumpf (1880-1962). In: Země a její muzeum. Slezské zemské muzeum a muzejní tradice českého Slezska (Šíl, J. a kol., edd.), 217. Opava.

- 2014a: Heslo II/11.2. Nálezy z vykopávek vídeňské archeologické společnosti v roce 1903. In: Země a její muzeum. Slezské zemské muzeum a muzejní tradice českého Slezska (Š́́l, J. a kol., edd.), 119. Opava.

- 2014b: Heslo II.11.3. Prsten s křišt’álovou muglí z Holasovic. In: Země a její muzeum. Slezské zemské muzeum a muzejní tradice českého Slezska (Š́́l, J. a kol., edd.). 120. Opava.

- 2014c: Heslo III/4.2. Viktor Karger (1880-1886) a jeho význam pro slezskou archeologii. In: Země a její muzeum. Slezské zemské muzeum a muzejní tradice českého Slezska (Š́́l, J. a kol., edd.), 214. Opava.

- 2014d: Heslo III/4.2.1. Viktor Karger, Gustav Stumpf. Mapa archeologických nalezišt'. In: Země a její muzeum. Slezské zemské muzeum a muzejní tradice českého Slezska (Šíl, J. a kol., edd.), 214-215. Opava.

- 2014e: Heslo II/11.1. Výběr archeologických nálezů ze sbírky Muzea Matice opavské. In: Země a její muzeum. Slezské zemské muzeum a muzejní tradice českého Slezska (Š́l, J. a kol., edd.), 117. Opava.

SKALICKÁ, P.-MARETHOVÁ, B., 2013: Středověká dřevohliněná zástavba domovního bloku. Předběžné shrnutí výsledků předstihového výzkumu v prostoru bývalé Radniční ulice v Opavě - Medieval wood-and-clay housing development of the house block - premilliary summary of archeological research in the former Radniční street in Opava, ČSZM B 62, 2013, 253-271.

- 2014: Archeologický výzkum při bývalé Radniční ulici v Opavě - Badania archeologiczne na dawnej ulicy Ratuszowej w (Radniční ulice) w Opawie, Badania archeologiczne na Górnym Śłąsku i ziemiach pogranicznych w 2011-2012 roku, 126-134.

SKALICKÁ, P.-ŠíL, J., 2014: Heslo IV/8. Lumír Jisl (1921-1969). In: Země a její muzeum. Slezské zemské muzeum a muzejní tradice českého Slezska (Š́́l, J. a kol., edd.), 323. Opava.

SKLENÁŘ, K., 1970: Archeologické spisy Josefa Dobrovského a jejich prameny - Archölogische Schriftstücke von Josef Dobrovský und deren Quellen, SbNM A XXIV, 245-295.

- 1971: Jan Erazim Vocel a počátky archeologické vědy v Čechách (K 100. výročí Vocelova úmrtí), PA LXII, 315-321.

- 1981: Jan Erazim Vocel. Zakladatel české archeologie. Praha.

- 2005: Biografický slovník českých, moravských a slezských archeologů a jejich spolupracovníků z př́ibuzných oborů. Praha.

SKLENÁř, K.-VLAŠÍMSKÝ, P., 2015: Freising Hans 18. 1. 1905 - 8. 12. 1977. In: Biografický slovník českých zemí 18, 372-373. Praha.

SKUTIL, J., 1946: Slezsko, český stát a česká kultura. In: Slezsko, český stát a česká kultura. Cyklus přednášek pořádaný Masarykovou univerzitou v Brně, 11-26. Opava.

SMETÁNKA, Z., 2008: Vzpomínky na minulost české archeologie I. Neviditelná kolej jako prostředek hledání nových cest - Remembering the Past of Czech archaeology I: The invisible college as a route to new approaches, AR LX, 733-754.

SPURNÝ, V., 1999: Vzpomínka na Lumíra Jisla (1921-1969), AR LI, 901-902.

STABRAVA, P., 1999: Archeologický výzkum kostela sv. Kateřiny v Kelči. In: Památkový ústav v Ostravě. Výroční zpráva 1998, 117-120. Ostrava.

- 1999a: Hradec nad Moravicí (o. Opava). Církevní škola Sv. Ludmily. Hrob, výrobní objekty - pece. Halštat, doba hradištní. Záchranný výzkum, PV 40 (1997-1998), 326-327.

- 2000: Záchranný archeologický výzkum na lokalitě Hradec nad Moravicí - Církevní škola sv. Ludmily, okres Opava, Badania archeologiczne na Górnym Śląsku i ziemiach pogranicznych w 1996 roku, 165-171.

- 2002: Stará Ves pod Ondřejnicí (okr. Frýdek-Místek). Zámek. Novověk. Záchranný výzkum, PV 43, 294-295.

- 2003: Archeologický výzkum na zámku ve Štáblovicích, okres Opava, Sborník Národního památkového ústavu v Ostravě, 28-39. 
- 2005: Hradec nad Moravicí (okr. Opava). Zámecká ulice 65. Raný středověk. Záchranný výzkum, PV 46, 284.

- 2011: Žárové pohřebiště na katastru města Příbora a jeho místo v regionálním vývoji kultury lužických popelnicových polí - A cremation burial ground on the cadaster of Příbor and its role in the regional development of Lusatian urn field culture, PV 52, č. 1, 75-110.

- 2014: Archeologický průzkum v domě č. 28 na náměstí Sigmunda Freuda v Př́iboře, Vlastivědný sborník Novojičínska 64, 165-178.

- 2017: Homo faber silvaticus. In: Říše prastará, mocná i zkrocená. Les na Kravařsku mezi středověkem a industrializací (Máchová, M.-Orlita, Z.-Stabrava, P., edd.), 93-103. Nový Jičín.

- 2017a: Sekery. In: Říše prastará, mocná i zkrocená. Les na Kravařsku mezi středověkem a industrializací (Máchová, M.-Orlita, Z.-Stabrava, P., edd.), 105-107. Nový Jičín.

STABRAVA, P.-TERYNGEROVÁ, H., 2001: Objev středověkého zahloubeného objektu v Hlučíně. In: Památkový ústav v Ostravě. Výroční zpráva 2000, 141-145. Ostrava.

STUMPF,G., 1912: Ruine Reichenstein, Altwater 30, 111-114.

- 1915: Ruine Reichenstein bei Jeuernig, Zeitschrift für Geschichte und Kulturgeschichte Österreichische Schlesiens 10, 73-78.

- 1921: Die vor- und frühgeschichtliche Ausstellung in Troppau, Das Kuhländchen 3, 7, 56.

- 1926: Neue vorgeschichtliche Funde vom Kotoutsch, Das Kuhländchen 9, 129-134.

- 1928: Funde aus Burgwällen, Nachrichtenblatt für deutsche Vorzeit 4, 121-122.

SVOBODOVÁ, H.-BARTOŠ, M.-NÝVLTOVÁ FIŠÁKOVÁ, M.-KOUŘIL, P., 2015: Genetic analysis of possibly the oldest greyhound remains within the territory of the Czech Republic as a proof of a local elite presence at Chotěbuz-Podobora hillfort in the 8th-9th century AD, SbNM B LXXI, 17-24.

SWIAČ, M., 2012: Expozice Ve znaku zavinuté střely II. v Muzeu Novojičínska. Rkp. magisterské diplomové práce ÚAM FF MU v Brně, ved. práce Mgr. Pavel Holman.

ŠEBELA, L., 2005: Jiří Pavelčík sedmdesátníkem - Jiří Pavelčík zum Siebzigsten Geburtstag, PV 46, $330-343$.

ŠEFČÍK, E., 1978: Novojičínský archeolog a vlastivědný pracovník Gustav Stumpf, Vlastivědný sborník okresu Nový Jičín 39, 50-51.

- 1981: Václav Vendl - zapomenutý opavský muzejní a kulturní pracovník, ČSZM B 35, 184-192.

- 1982: Městské muzeum v Opavě v letech 1896-1945, Ročenka okresního archivu v Opavě, 59-61.

- 1984: Přehled vývoje opavských muzeí v letech 1814-1938, ČSM B 33, 1-44.

- 1987: K činnosti Viktora Kargera v Opavě, Těšínsko 1, 28-29.

- 1987a: Novojičínský archeolog a vlastivědný pracovník Gustav Stumpf, Vlastivědný sborník okresu Nový Jičín 39, 50-52.

ŠERÝ, Z.-TICHÁNEK, J., 2003: Šlechtická sídla na Novojičínsku. Opava.

ŠIKULOVÁ, V., 1958: Moravská pohřebiště z mladší doby hradištní, Pravěk východní Moravy 1, 88-162.

- 1964: Výzkumy pravěkého oddělení Slezského muzea v roce 1963, Opavsko 10, 16-18.

- 1966: Dvacet let archeologické práce na území opavského okresu, Opavsko 12, 27-32.

- 1966a: Nejstarší opavská studna - Der älteste Brunnen in Opava (Troppau), ČSM B 15, 3-11.

- 1968: Památky na slovanský kmen Holasiců. Praha.

- 1968a: Předběžná zpráva o výzkumu kostela sv. Václava v Ostravě - Vorbericht ober die ausgrabungen in der st. Wenzelskirche zu Ostrava, PV 12, 101-103.

- 1968b: Záchranné akce v areálu středověké Opavy - Rettungsaktionen im Bereich des mittelalterlichen Opava, PV 12, 100-111.

- 1969: Dr. Lumír Jisl zemřel, Informace Slezského muzea 3, prosinec 1969, 1-3.

- 1970: Krypta v moravské kapli kostela sv. Václava v Opavě - Die Krypta in der mährischen Kapelle der st. Wenzelskirche in Opava, PV 13, 67-70.

- 1970a: Pokračování výzkumu v kostele sv. Václava v Ostravě (okr. Opava) - Fortsetzung der Grabung des Dominikaner Klosters in Opava (Bez. Opava), PV 14, 57-58.

- 1971: Pokračování záchranných akcí v areálu středověké Opavy - Fortsetzung der Rettungsaktion im Areal des mittelalterlichen Teiles der Stadt Opava, PV 115, 69-74. 
- 1971a: Záchranné výzkumy na přestavbě státní silnice Opava-Krnov (okr. Opava) - Rettungsgrabungen beim Umbau der Staatsstrasse Opava-Krnov, PV 15, 76-77.

- 1972: Stř̌edověké nálezy z Vávrovic (okr. Opava) - Mittelalterliche Funde aus Vávrovice (Bez. Opava), PV 16, 111-112.

- 1972a: Záchranné akce v areálu středověké Opavy (okr. Opava) - Rettungsgrabungen im Areal des mittelalterlichen Troppaus (Bez. Opava), PV 16, 121-124.

- 1973: Nálezy z hradu Vikštejna, obec Radkov-Dubová (okr. Opava) - Funde aus der Burg Vikštejn, Gemeinde: Radkov-Dubová (Bez. Opava), PV 17, 87-88.

- 1973a: Záchranné akce v areálu středověké Opavy (okres Opava) - Bergungsaktionen im Areal des mittelalterlichen Opava, PV 17, 90-91.

- 1974: Archeologický výzkum v dominikánském klášteře, Naše Opavsko, 13. 7. 1973, 4.

- 1975: Př́spěvek archeologie ke stř̌edověkým dějinám Opavy - Der Beitrag der Archäologie zur mittelalterlichen Geschichte von Opava, AR XXVII, 270-276.

- 1977: Nálezy mincí z výzkumu středověké Opavy a Ostravy. In: Středověká archeologie a studium počátků měst. Sborník př́spěvků přednesených na celostátní konferenci stř̌edověkých archeologů v Hradci Králové, 22.-27. září 1975 (Richter, M., ed.), 141-149. Praha.

- 1978: Pokračování výzkumu dominikánského kláštera v Opavě (okr. Opava), PV 21, 87-88.

- 1982: Zpráva o pokračování výzkumu dominikánského kláštera v Opavě - Bericht über die Fortsetzung der Untersuchungen des Dominikanerklosters in Opava (Troppau), VVM XXXIV, 206-208.

- 1985: Středověká polévaná keramika z Opavy - Mittelalterliche glasierte Keramik aus Opava (Troppau), AH 10, 230-233.

- 1990: Záchranný výzkum v bývalém dominikánském kostele sv. Václava v Opavě (okr. Opava), PV 32, 76-77.

- 1991: Archeologické pracoviště Slezského zemského muzea v Opavě, Pravěk NŘ 1, 24-26.

- 1991a: Polévaná konvice, v níž byl uložen poklad brakteátů v Rešově - Eine bewässerte Teekanne, in der Schatz der Brakteaten in Rešov aufbewahrt wurde, okr. Bruntál, ČSZM B 40, 9-13.

- 1991b: Přehled dokladů středověkého osídlení Kotouče ve sbírkách Slezského muzea v Opavě, Vlastivědný sborník okresu Nový Jičín 47, 62-65.

- 1993: Vysvětlení ke středověkému prstenu z Holasovic (okr. Opava) - Erläuterung zum mittelalterlichen Fingerring aus dem Holasovice (Kreutzendorf), Bez. Opava (Troppau), ČSZM B 42, 13-16.

- 1999: Hesla č. 122-128. In: Od gotiky k renesanci. Výtvarná kultura Moravy a Slezska 1400-1450. IV. Opava (Chamonikola, K., ed.), 227-229. Brno.

- 2004: Habánské umyvadlo Jana Jiřího Krnovského nalezené v Opavě - Das Habaner Waschbechen von Johan Georg von Jägerndorf in Opava, Sborník k dějinám města 4, 19-28.

- 2012: Archaeologica II. Hesla kat. č. 4-6. In: Znamení vertikál. Církevní a náboženský život českého Slezska od středověku po první světovou válku (Šopák, P. a kol., edd.), 119-125. Opava.

ŠIKULOVÁ, V.-ZEZULA, M., v tisku: Exkurz 1. Dvůr v Holasovicích ve světle archeologických nálezů z přelomu raného a vrcholného středověku. In: Holasovice - Loděnice - Štemplovec - Kamenec. Dějiny obcí (Rosová, R. a kol., edd.). Holasovice.

ŠíL, J., 2010: Vincenc Prasek (1843-1912): má vůle je mým osudem. Opava.

ŠíMA, J., 1970: Za Lumírem Jislem, Nový Orient 52, č. 1, 17.

ŠOPÁK, P., 2001: Václav Karel Vendl jako historik umění - Václav Karel Vendl als Kunsthistoriker, ČSZM B 50, 184-192.

- 2006: Opavská léta Karla Černohorského - Die Troppauer Jahre Karel Černohorskýs, ČMMZ 91, 155-165.

- 2008: Edmund Wilhelm Braun. Opava.

ŠTĚRBOVÁ, J.-PAVELČÍK, J., 1997: Macákové z Ottenburku (historie jednoho opavského domu ve světle archivních pramenů a archeologického výzkumu) - Die Macaks von Ottenburg, Sborník prací Filozofické fakulty Ostravské univerzity 5, 145-172.

TERYNGEROVÁ, H., 1995: Předběžná zpráva o hromadném nálezu gotického skla v Opavě, Sborník Památkového ústavu v Ostravě, 30-33.

- 1996: Kostěné artefakty z archeologického výzkumu na Ostrožné ulici v Opavě, Sborník Památkového ústavu v Ostravě, 69-72. 
- 1997: Opava (okr. Opava). Dolní nám. 22, čp. 304 (parc. č. 387/1 st.). Sídliště - město. Středovek (13.-14. stol.). Záchranný výzkum, PV 38, 226-227.

- 1999: Dřevěné konstrukce z archeologických výzkumů historických jader v Opavě a Ostravě (v sezónách 1992-1998). In: Památkový ústav v Ostravě. Výroční zpráva 1998, 109-112. Ostrava.

- 1999a: Opava (okr. Opava), Dolní nám. 21. Středovek a novověk. Město. Záchranný výzkum, PV 39, 446-449.

- 2000: Neobvyklý nález drobné devocionálie z výzkumu v Opavě, Ostrožná ulice - předběžná zpráva. In: Památkový ústav v Ostravě. Výroční zpráva 1999, 105-109. Ostrava.

- 2001: Záchranný archeologický výzkum na hlučínském zámku. In: Památkový ústav v Ostravě. Výroční zpráva 2000, 146-147. Ostrava.

- 2002: Středověké poutnictví a jeho odraz v archeologickém materiálu. K nálezu poutního odznaku z Opavy. In: Pro arte. Sborník k poctě Ivo Hlobila (Prix, D., ed.), 31-34. Praha.

- 2008: Ostrava (k. ú. Moravská Ostrava, okr. Ostrava). Puchmajerova ulice, p. č. 3494/2, 3494/1. Středověknovověk. Město, hřbitov. Záchranný výzkum, PV 49, 464-465.

- 2009: Ostrava (k. ú. Kunčice nad Ostravicí, okr. Ostrava). Frýdecká ulice 30, p. č. 1/1, PV 50, 425-426.

TICHÁNEK, J., 2005: Šlechtická sídla na Frýdecko-Místecku. Kopřivnice.

TITZE, W., 1941: Bericht über die Begehung vor- und frühgeschichtlichen Fundplätze in der näheren Umgebung von Troppau. NZ č. j. 358/91, ulož. v archivu ARÚ v Brně.

TVRDÝ, Z., 2008: Antropologický materiál z kostela sv. Václava v Ostravě - Die Gebeine von der St. Wenzel-Kirche in Ostrava. In: Moravskoslezská škola doktorských studií. Seminář 1 (Měřínský, Z.-Klápště, J., edd.), 212-215. Brno.

TYMONOVÁ, M., 2005: Archeologické sbírky ve slezských muzeích - historie, současný stav a perspektivy využití z hlediska ochrany kulturního dědictví - Archäologische Sammlungen in den schlesischen Museen - Geschichte, der gegenwärtige Stand und Perspektiven, Ausnützung aus der Schutzsicht der Kulturerbschaft, AH 30, 79-93.

- 2009: Stř̌edověké reliéfní kachle jako pramen hmotné kultury (Slezsko) - Mittelalterliche Reliefkacheln als Quelle der Sachkultur (Schlesien), AH 34, 209-223.

- 2010: Archeologické doklady každodenního života obyvatel hradu Cvilína ve středověku a raném novově$\mathrm{ku}$ - Archäologische Belege des Alltagslebens der Bewohner von Burg Cvilín in der Zeit des Mittelalters und der frühen Neuzeit, AH 35, 63-79.

- 2011: Gotické a renesanční kachle ze slezských hradů - Gothic and Renaissance Tiles from Silesian Castles. Rkp. nepubl. disertační práce ÚAM FF MU, Brno. Díl I.-III., vedoucí práce doc. PhDr. P. Kouřil, CSc.

- 2012: Renesanční kachle s dvanácti biblickými hrdiny a tyrany z českého Slezska - Renaissancekacheln mit zwölf biblischen Helden und Tyranen vom tschechischen Gebiet Schlesiens, AH 37, 679-690.

- 2015: Medailonové kachle z Javorníka Medailonové kachle z Javorníka - Die Medaillonkacheln aus Javorník, AH 40, 941-959.

- 2016: Kachlové soubory z Frýdku - Die Kachelkollektionen aus Frýdek, AH 41, 415-435.

- 2017: Příspěvek k datování zrcadlových kachlů - Ein Beitrag zur Datierung von Spiegelkacheln, AH 42 , 875-899.

TYMONOVÁ, M.-ŽÁKOVSKÝ, P., 2012: Železný meč ze Stěbořic - Iron Word from Stěbořice. In: Mezi raným a vrcholným středověkem. Pavlu Kouřilovi k šedesátým narozeninám přátelé, kolegové a žáci (Doležel, J.-Wihoda, M., edd.), 611-623. Brno.

ÚLOVEC, J., 1996: Herbert Weinelt a jeho výzkumy panských sídel - Herbert Weinelt und seine Untersuchungen der Herrensitze, CB 5, 11-22.

UNGER, J., 1971: Stav a úkoly archeologického výzkumu opevněných sídel drobné středověké šlechty na Moravě - Состояние и задачи исторического изучения укрепленных усадеб мелкой знати в Моравии, SPFFBU E 16, 229-231.

VACHŮT, P., 2008: Historie archeologických výzkumů raně středověkých pohřebišt’ na území Moravy a Slezska - Geschichte der archäologischen Grabungen frühmittelalterlicher Gräberfelder auf dem Gebiet Mährens und Schlesiens. In: Moravskoslezská škola doktorských studií. Seminář 1 (Měřínský, Z.-Klápště, J., edd.), 175-186. Brno. 
VÁŇA, Z., 1970: † PhDr. Lumír Jisl, AR XXII, 206-207.

VAŠKOVÝCH, M.-MENOUŠKOVÁ, D., 2004: Doklady archeologického osídlení středního Pomoraví. Soupis nalezišt' z katastrů obcí: Babice, Huštěnovice, Jarošov, Kněžpole, Kostelany nad Moravou, Kunovice, Mařatice, Míkovice, Nedakonice, Ostrožská Nová Ves, Polešovice, Spytihněv, Topolná, Uherský Ostroh, Vésky - Belege der archäologischen Besiedlung von mittlerem Marchgebiet. Verzeichnis der Fundstellen auf den Katastern der folgenden Gemeinden: Babice, Huštěnovice, Jarošov, Kněžpole, Kostelany nad Moravou, Kunovice, Mařatice, Míkovice, Nedakonice, Ostrožská Nová Ves, Polešovice, Spytihněv, Topolná, Uherský Ostroh, Vésky, Slovácko 46, 109-141.

VEČĚ̌A, J., 2002: Historie dolování ve zlatohorském rudním revíru - Die Geschichte des Bergbaus im Erzrevier von Zlaté Hory (Zuckmantel), Vlastivědný sborník Jesenicka 3, 18-31.

- 2014: Kolonizační snahy ve 13. století a nerostné bohatství Jeseníků, Forum urbes medii aevi 8, 16-21.

VEČEŘA, J.-MALÍK, P.-ZEZULA, M., 2014: Suchá Rudná - záchranný archeologický výzkum a geologická charakteristika lokality Suchá Rudná - archeological rescue work and the geological characteristics of the locality, Acta rerum naturalium 16, 75-84.

VEČEǨA, J.-VEČEŘOVÁ, V., 2010: Historie zlatohorských dolů - History of minig in Zlaté Hory. Jeseník. VOJKU゚VKOVÁ, K.-ZEZULA, M., ed., 2012: Předměty vyprávějí... Hmotná kultura středověké a raně novověké Opavy ve světle nálezů z archeologických výzkumů v prostoru bývalé Radniční ulice a v areálu opavského pivovaru. Ostrava.

WEINELT, H., 1934: Die Schellenburg, ein Musterbeispil einer schlawischen Herrenburg. Deutsch-mährisch-schlesische Heimat 20, č. 11-12, 277-280.

- 1934a: Die Burgen des Würbenthaler Gebietes, Freudenthaler Ländchen 14, č. 7, 47-51.

- 1936: Probleme schlesische Burgenkunde, gezeigt an den an den freiwaldauer Bezirkes. Breslau.

WIEGANDOVÁ, L., 1972: Středověké tvrziště Přerovec u Štítiny (okr. Opava) - Die mittelalterliche Feste Přerovec bei Štítina (Bez. Opava), PV 1971, 119-120.

- 1972a: Středověký hrad ve Slezské Ostravě (okr. Ostrava) - Die mittelalterliche Burg in Slezská Ostrava (Bez. Ostrava), PV 16, 102-103.

- 1973: Další nálezy z kostela sv. Václava v Ostravě (okr. Ostrava) - Weitere Funde aus der Kirche des H1. Wenzels in Ostrava (Bez. Ostrava), PV 17, 92.

- 1973a: Výzkum na Slezsko-ostravském hradě (okr. Ostrava) - Grabung auf der Schlesisch-Ostrauer Burg (Bez. Ostrava), PV 17, 88-89.

WIHODA, M., 1997: Přemyslovská expanze v Horním Slezsku a vznik holasické provincie - Die Expansion der Přemysliden in Oberschlesien und die Entstehung der Holasitzer Provinz, Acta historica et museologica Universitatis Silesianae Opaviensis 3, 34-43.

- 1997a: Mocenský zápas českého a polského státu v 11. a 12. století - Der Macht des böhmisches und polonischen Staates im 11. und 12. Jahrhundert, SBFFBU C 44, 5-15.

- 1998: Geneze městského zřízení na Opavsku jako zakladatelské dílo markraběte Vladislava Jindřicha Die Genesis der Stadtverfassung in Mähren als Gründunsvorhaben des Markgrafs Vladislav Jindřich, SPFFBU C 45, 21-34.

- 1999: Slezsko v genezi středoevropského mocenského systému do poloviny 14. století, Slezský sborník 97, č. 2, 129-134.

- 2005: Die mährischen Eliten als Problem der Kontinuität (oder Diskontinuität?) der böhmischen Geschichte. In: Die frühmittelalterliche Elite bei den Völkern des östlichen Mitteleuropas (mit einem speziellen Blick auf die grossmährische Problematik), Spisy Archeologického ústavu AV ČR Brno 25, 9-18.

- 2006: Morava v 10. století. In: České země v raném středověku (Sommer, P., ed.), 53-73. Praha.

- 2012: Morava knížete Břetislava I. In: Mezi raným a vrcholným středověkem. Pavlu Kouřilovi k šedesátým narozeninám prrátelé, kolegové, žáci (Doležel, J.-Wihoda, M., edd.), 421-431. Brno.

WOCEL, J. E., 1850: Česká archeologie křest’anského starověku (úvodní čtení předneseno 6. 11. 1850 na univerzitě Pražské), Časopis českého museum 24, 514-555.

ZEZULA, M., 2003: Archeologie a počátky Moravské Ostravy (Archeologické výzkumy v historickém jádru města v letech 1998-2002). In: Ostrava. Př́íspěvky k dějinám a současnosti Ostravy a Ostravska 21, 7-44. Ostrava. 
- 2008: Opava (k. ú. Opava - Město, okr. Opava). Drůbeží trh, PV 49, 425-426.

- 2009: Archeologický výzkum v kostele sv. Benedikta, raně středověké Krnovsko a počátky města Krnova ve světle archeologických nálezů - The Church of St. Benedict, the Krnov area in the Early Middle Ages, and the beginnings of the town of Krnov in the light of archeological finds. In: Kostel sv. Benedikta v Krnově-Kostelci (Prix, D., ed.), 129-171. Ostrava.

- 2013: Archeologické výzkumy v prostoru bývalého opevnění města Opavy. In: Opavské hradby (Kolár, F., ed.), 28-35. Opava - Ostrava.

- 2013a: Hrnčířská pec z Velkých Heraltic a její vztah k nejstaršímu horizontu opavské středověké keramiky - Pottery Kiln form Velké Heraltice and its Relation to the Oldest Horizon of Opava Middle Ages Pottery, ČSZM B 62, 301-318.

- 2013b: K životnímu a pracovnímu jubileu Vlasty Šikulové, ČSZM B 62, 101-106.

- 2014: Nejstarší osídlení Frýdecko-Místecka. In: Frýdek-Místek. Historie - Kultura - Lidé (Adamec, T. a kol., edd.), 13-28. Praha.

- 2015: Odraz konzumace piva v archeologických nálezech z Opavy. In: Opavský pivovar (Dorko, B. et al., edd.), 100-115. Opava.

- 2017: Archeologické prameny: Nejstarší osídlení a počátky města. In: Antonín, R. et. al., Ostrava. Počátky a vývoj středověkého města. Ostrava, 46-69. Ostrava.

- 2017a: Archeologické prameny: Podoba středověké Ostravy. In: Antonín, R. et. al., Ostrava. Počátky a vývoj středověkého města, 80-97. Ostrava.

- 2019: Vybrané problémy vrcholně středověké transformace moravsko-slezského pomezí (ve světle archeologických pramenů) - Selected issues in the High Medieval transformation of the Moravian-Silesian border region (evidence from archeological sources). Rkp. disertační práce na FF UK v Praze, ved. práce PhDr. Tomáš Klír, Ph.D.

ZEZULA, M.-KIECOŇ, M.-KOLÁŘ, F., 2007: Archeologické doklady k vývoji půdorysu, uliční sítě a parcelace středověké Opavy - Archäologische Belege zur Entwicklung des Grundrisses, des Straßennetzes und der Parzellierung im mittelalterlichen Troppau (Opava), Forum urbes medii aevi IV, 118-143.

ZEZULA, M.-MORAVEC, Z.-KOČÁR, P.-SU゚VOVÁ, Z., 2009: Archeologické výzkumy na Masarykově náměstí v Ostravě a jejich výpověd' $\mathrm{k}$ vývoji, hmotné kultuře a životnímu prostředí města ve středověku a raném novověku. In: Ostrava. Př́íspěvky k dějinám a současnosti Ostravy a Ostravska 24, 538-579. Ostrava

ŽÁKOVSKÝ, P., 2013: „,... s tesákem aby žádný v městečku do krčmy nechodil, pakli bude choditi, jdi na své právo“, aneb nález tesáku v pochvě z Opavy, ČSZM B 62, 319-338.

- 2018: „Znovuobjevený“ tesák z hradu Rychleby u Javorníka, VVM LXX, 192-196.

\section{Zusammenfassung}

\section{Die Mediävale Archäologie in Tschechisch-Schlesien}

In der Geschichte der archäologischen Forschung in Tschechisch-Schlesien und dem benachbarten Teil des nordwestlichen Mährens können vier Etappen unterschieden werden. Die erste wird mit dem Anfang des 19. Jahrhunderts abgegrenzt, als man damit begann, archäologische Funde zu retten (Abb. 1). Dabei handelte es sich um eine zufällige, mit der Entstehung der ältesten archäologischen Sammlungen verbundene Tätigkeit. In der zweiten Etappe hat sich nach dem Jahr 1918 die mehr oder weniger passive Aufbautätigkeit von Sammlungen nach und nach zu einer systematischen Zusammentragung von archäologischen Funden gewandelt, was mit der Durchführung von Geländegrabungen, die Besiedelung resümierenden Veröffentlichungen und der Präsentation der bedeutendsten Denkmäler verbunden war. Die archäologische Forschung konzentrierte sich mit der Zeit auf das Kunstgewerbemuseum in Opava, wo sich Viktor Karger (Abb. 2) und Gustav Stumpf (Abb. 3) um den Aufbau einer modernen Arbeitsstätte verdient gemacht haben, die in dem hinsichtlich Sprache und Nationalität deutschen Gebiet mit der 
Professionalisierung der archäologischen Arbeit begannen. Für die Sammlungen hat man damals Material von den auf Burg Cvilín (Schellenburg) erfolgten Grabungen erworben (Abb. 4) und es wurden mehrere frühmittelalterliche Befestigungen dokumentiert, darunter auch die Burgstätte in Kylešovice (Abb. 5). Ein zweites Zentrum wurde in Ostrava ins Leben gerufen und war mit der Tätigkeit von Karel Jaromír Bukovanský verbunden, dessen Sammlungen im Jahr 1924 vom städtischen Museum als direktem Vorgänger des heutigen Ostrauer Museums übernommen wurden. In der dritten Etappe konzentrierte sich die Grabungstätigkeit nach dem Jahr 1945, als die archäologische Forschung in tschechische Hände überging, auf die slawische Zeit, auf befestigte mittelalterliche Sitze und im Rahmen des Nachkriegswiederaufbaus auf Ausgrabungen von Städten. Die erste Nachkriegsgrabung wurde im Jahr 1946 von Josef Poulík vom Staatlichen archäologischen Institut in Brünn an der Burgstätte in Kylešovice durchgeführt. In ihrer Nähe hatte man im Jahr 1881 ein Hortfund von Silberdenaren mit einer Plastik des Lamm Gottes gefunden (Abb. 6). Weitere Grabungen wurden von Lumír Jisl durchgeführt (Abb. 7), der im Jahr 1955 in Opava eine Expositur des Archäologischen Institutes der Tschechoslowakischen Akademie der Wissenschaften in Brünn gründete. Grundlegende Veränderungen in der Struktur der archäologischen Organisationen stellten sich nach dem Jahr 1989 ein, als neue archäologische Institutionen in der Region tätig zu sein begannen. Im Jahr 1992 wurde in Opava die Zweigstelle des Brünner Instituts aufgelöst, die im darauffolgenden Jahr dem Denkmalamt in Ostrava unterstellt wurde. Mitte der neunziger Jahre wurde der Aufbau der archäologischen Arbeitsstätte an der Schlesischen Universität zu Ende geführt, deren Studenten im Rahmen der Geländepraxis eine Reihe von Grabungen durchführten (Abb. 9). Im Jahr 2003 wurde in Opava die Zweigstelle des Brünner archäologischen Instituts wiedereröffnet, die seit dem Jahr 1979 an der Burgstätte in Chotěbuz-Podbora eine systematische Grabung durchgeführt hatte (Abb. 10). In der Region begann auch die gemeinnützige Gesellschaft Archaia tätig zu werde, die mit der Universitätsarbeitsstätte zusammenarbeitet.

PhDr. et PhDr. Markéta Tymonová, Ph.D., Ústav archeologie Filozoficko-přírodovědecké fakulty Slezské univerzity v Opavě, Bezručovo náměstí 13, 74601 Opava, Česká republika, marketa.tymonova@fpf.slu.cz 
